\title{
33. EARLY CRETACEOUS TURBIDITE SEDIMENTATION AT DEEP SEA DRILLING PROJECT SITE 603, OFF CAPE HATTERAS (LEG 93) ${ }^{1}$
}

\author{
Massimo Sarti, Istituto di Geologia, Università di Ferrara \\ and \\ Ulrich von Rad, Bundesanstalt für Geowissenschaften und Rohstoffe ${ }^{2}$
}

\begin{abstract}
A 300-m-thick, upper Valanginian to Barremian turbidite sequence, consisting of sandstone and organic-matter-rich claystone turbidites intercalated in pelagic marl and limestone, was discovered at Site 603, on the lower continental rise off North America.

Many of the turbidites consist of clayey sandstone beds, 1 to $1.5 \mathrm{~m}$ thick, containing abundant claystone clasts and displaying no or incomplete Bouma sequences. Sedimentary structures suggest that such beds were dominantly emplaced by viscous flows (sandy debris flows). The turbiditic sequence is topped by $40 \mathrm{~m}$ of clean, uncemented sands of ?Barremian-Aptian áge.

The development of different turbidite facies and facies associations at Site 603 is related to regional geology, variations in the type and amount of sediment supplied, and changes in sea level. We consider that the Hauterivian-Barremian lower turbidite sequence was deposited at times of high or rising sea level in a sediment-starved, channel-dominated turbidite system. Sedimentological and seismic data favor the hypothesis of a structurally confined "channel-levee complex" characterized by an efficient network of channels for distributing sand to the deep sea. High-energy turbidite facies suggest that turbidity currents might have been confined within levees of major channels while passing by Site 603 . Erosion at channel levees may explain the abundance of shale clasts within the turbidites. The claystone lithology of ripup clasts indicates a probable levee origin. The hummocky reflection configuration supports the channel-levee hypothesis. At the same time as the lower turbidites were deposited, large amounts of terrigenous sediments were trapped on the shelf (Wealden-type facies). The upper, unconsolidated sand unit reflects a sudden input of shelf sand, thought to correspond to a phase of shelf destruction after the sea level dropped in middle Aptian time. A late Aptian-early Albian sealevel rise terminated the turbidite deposition, caused the change from carbonate-rich to carbonate-free pelagic sedimentation (CCD rise), and promoted the development of anoxic bottom waters which enhanced preservation of organic matter ("black shales").
\end{abstract}

\section{INTRODUCTION}

The topic of modern and ancient turbidite sedimentation has received much attention in recent years, since exploration for new offshore hydrocarbon resources renewed interest in turbidite basins and deep-sea clastic reservoirs.

The Deep Sea Drilling Project has provided a conspicuous amount of data on deep-sea clastic sedimentation (Kelts and Arthur, 1981) and has significantly contributed to the understanding of turbidite deposition. Although turbiditic fans were only rarely the primary objectives of DSDP studies, a number of holes drilled in different fan settings provided valuable data about the deep stratigraphy of modern and ancient turbidite systems (Kelts and Arthur, 1981). The deep stratigraphy of modern fans is poorly known because it is inaccessible by ordinary piston-coring procedures. During Leg 96 of the Deep Sea Drilling Project, cores as long as several hundred meters were obtained from the Mississippi Fan (Bouma, Coleman, et al., 1984), shedding new light on passive-margin fan deposition. Furthermore, Leg 93 offered a unique opportunity to study facies and sequences of an ancient, passive-margin turbidite system in the

\footnotetext{
${ }^{1}$ van Hinte, J. E., Wise, S. W., Jr., et al., Init. Repts. DSDP, 93: Washington (U.S. Govt, Printing Office)

2 Addresses: (Sarti) Istituto di Geologia, Università di Ferrara, 144100 Ferrara, Italy (von Rad) Bundesanstalt für Geowissenschaften und Rohstoffe, D-3000 Hannover 51, Federa Republic of Germany.
}

western North Atlantic. Facies from such types of systems are virtually unknown from outcrops, which usually expose only limited segments of active-margin flysch sequences.

Leg 93 was originally planned to drill a single, deep hole at the lower continental rise off North America (Fig. 1) through the Mesozoic and into the Jurassic oceanic basement. It missed its main target because of technical failure, but unexpectedly recovered a thick and fairly continuous sequence of turbidites (see Site 603 chapter, this volume). Such an extensive turbidite succession had not previously been recovered in any of the western North Atlantic Basin DSDP sites (e.g, 105, 387, 99, 100, 101), although its presence was predicted in some places on the basis of data from seismic profiles and commercial wells (Jansa and McQueen, 1978). The interest of the Lower Cretaceous turbidite succession off the U.S. east coast is sedimentological and regional: it gives new insight into the previously unexplored passive-margin turbidite deposition and provides constraints upon the Early Cretaceous sedimentary history of the eastern U.S. continental margin.

The turbidite facies and the seismic characteristics of the turbiditic sequence will be described in Part 1 of this chapter. The sedimentology of the Blake-Bahama Formation (Berriasian-Aptian) in general, and of the pelagic lithotypes in particular, is covered in the companion paper by Ogg et al., this volume. In Part 2 of this chapter, we attempt to interpret both the site of deposi- 


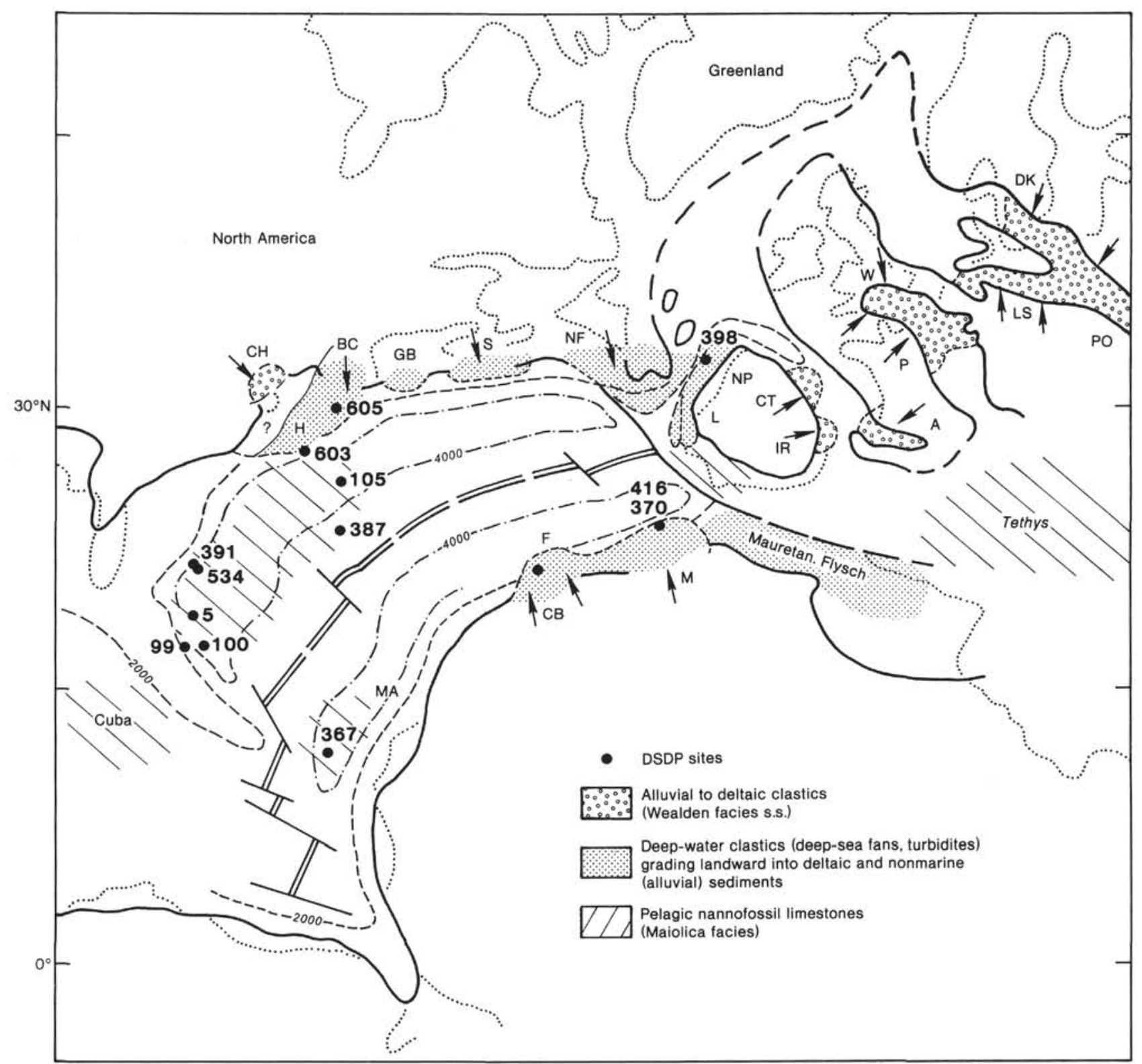

Figure 1. Early Cretaceous (Valanginian, 125 Ma) geography of the North Atlantic, showing the location of Site 603 and selected DSDP sites at which drilling reached Cretaceous sediments. Paleogeography and paleobathymetry ( 2000 and $4000 \mathrm{~m}$ isobaths, shown by dashed lines) modified after McCoy and Zimmermann (unpublished data) and various other sources; facies, after von Rad and Arthur (1979) and Robertson and Bernoulli (1982). Heavy lines are ancient coastlines, dotted lines are present coastlines, the double lines represent ancient spreading centers, and the arrows the estimated directions of sediment supply. $\mathrm{A}=$ Aquitaine Basin (Parentis and Adour basins), $\mathrm{BC}=$ Baltimore Canyon Trough, $\mathrm{CB}=$ Cape Bojador marginal basin, $\mathrm{CT}=$ Cantabrian Trough, $\mathrm{CH}=\mathrm{Chesapeake}$ Bay $($ Potomac Formation), DK = eastern Denmark and southern Sweden, F = Fuerteventura "flysch," GB = Georges Bank Basin, H = Hatteras Fan, IR = Iberic Ranges (Sierra de los Cameros, Maestrazgo Basin), L = Lusitanian Basin, LS = "Wealden" of Lower Saxony and Central Germany, M = "Atlas Gulf"/Moroccan Basin, MA = Maio Island, NF = eastern Newfoundland and Flemish basins, NP = NorthPortuguese-Galician Basin, $\mathrm{P}=$ Paris Basin, $\mathrm{PO}=$ Poland, $\mathrm{S}=$ Scotian Basin, $\mathrm{W}=$ "Wealden" of southeast England.

tion of the Site 603 turbidites and the main sedimentary events with respect to sea-level changes, tectonics, and regional geology.

\section{FACIES AND STRATIGRAPHY}

\section{Turbidite Facies}

In the following chapter and in the figures, the facies classification and notations Mutti and Ricci Lucchi (1972) have been used (Fig. 2) as a purely descriptive tool with- out interpretative connotations. Capital letters designate the facies, lower-case letters the Bouma sequence divisions. " $T$ " followed by subscript lower case letters designates the Bouma-sequence types (e.g., $T_{a}, T_{b}, \ldots$ ).

\section{Shale-Clast-Rich, Clayey Sandstone Turbidites and "Slurried Beds"}

Many turbidites at Site 603 consist of clay-rich to clayey sandstone beds, approximately 1 to $1.5 \mathrm{~m}$ thick (Fig. 3). These beds display rudimentary or no Bouma sequences 


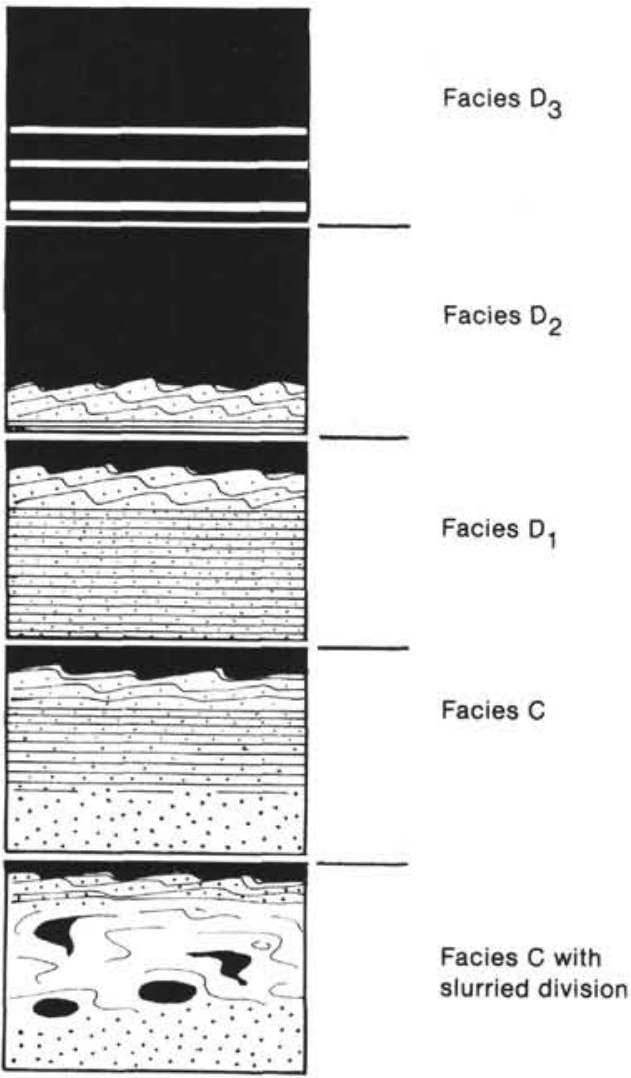

Figure 2. Turbidite facies after Mutti and Ricci Lucchi $(1972,1975)$. Facies D turbidites comprise sandstone beds $\left(\mathrm{D}_{1}\right)$, sandstone-claystone couplets $\left(\mathrm{D}_{2}\right)$ and claystone beds $\left(\mathrm{D}_{3}\right)$ displaying a Bouma sequence that is missing the basal division a (beginning from any one of the other divisions b, c, d, or e); facies C turbidites are sandstone and/or sandstone-claystone beds displaying a complete Bouma sequence (including the a division). Facies $\mathrm{C}$ turbidites may contain rip-up mudstone clasts, scattered or concentrated in a chaotic, clayey sandstone interval sandwiched between the massive division a and the current-laminated division $\mathrm{c}$ of the Bouma sequence ("slurried beds"; Marschalko, 1970; Van Vliet, 1978; Mutti et al., 1978; Mutti and Nilsen, 1981).

and are characterized by shale clasts, scattered or concentrated in breccia levels. The grain size is anomalously fine considering the thickness of the beds and ranges from medium to fine sand. Coarse-grained sandstones are rare.

Figure 4 illustrates four basic types of shale-clast-rich sandstone beds recognized in the succession at Site 603, corresponding to the facies $\mathrm{C}$ beds, with slurried division, of Fig. 2.

Type 1 to type 3 deposits are approximately 1 -m-thick, disorganized beds of medium- to fine-grained sandstone, having a clay content of 37 to $58 \%$ and showing virtually no size grading. Convolute laminations occur extensively in type 1 beds, and claystone/sandstone clasts, up to $10 \mathrm{~cm}$ across, are abundant. Clasts are equidimensional and elongate, rounded, flat, or irregularly shaped and plastically deformed. Clasts are scattered throughout the bed and do not show any preferred orientation (Plate 12, Fig. 1). Type 2 beds commonly have convolute and wavy lamination in their upper part. Claystone clasts are concentrated in nests near the top of the beds to form breccia layers (Plate 9; Plate 10, Figs. 2 and 3;
Plate 11; Plate 16 and Plate 17, Fig. 2; Plate 18, Fig. 2 right, and Plate 19, Fig. 2). Faint thick, irregularly wavy laminae are also common in most type 2 beds. Type 3 beds are massive and uniform in texture (Plate 18, Fig. 2, left), rarely showing faint, thick, parallel laminations. Claystone clasts are absent or rare; when present, they are small (1 to $2 \mathrm{~cm}$ across), rounded in shape, and scattered.

Type 1, 2, and 3 beds may all have at their base a carpet of clean sandstone, a few to $10 \mathrm{~cm}$ (exceptionally $25 \mathrm{~cm}$ ) thick. This basal layer is commonly massive and cemented by calcite (Plate 3; Plate 5; Plate 9; Plate 11). Calcite cement is always associated with low clay content (see Tables 1 and 2). Type 3 beds, despite their resemblance to thick-bedded sandstone of facies B of Mutti and Ricci Lucchi (massive bedding, Bouma sequence not applicable, parallel, thick laminae) cannot be ascribed to this category because their clay content is high and they lack diagnostic features such as extensive dewatering structures, large-scale current structures, or currentremolded top (Mutti and Ricci Lucchi, 1975).

Beds of type 4 are thinner deposits in which the shaleclast-rich, chaotic horizon is more consistently organized with respect to Bouma divisions. The "slurried" level (approximately one third or one quarter of the total thickness of the bed) is in fact sandwiched between the a and/ or $\mathrm{b}$ divisions of the Bouma sequence and the claystone top layer (Plate 13, Fig. 2; Plate 14, Fig. 1; Plate 16, left; Plate 18, Fig. 1, lower right). The rippled c division is commonly lacking. The basal sandstone may be cemented by calcite. Turbidite beds including intrasandstone slurries are here named "slurried beds," following a nomenclature first introduced by Mutti et al. (1978).

The lithology of rip-up clasts is in all cases vary uniform, being represented mostly by black claystone and rarely by sandstone. Clasts composed of pelagic lithologies are subordinate and occur in thicker beds (Plate 9, left).

\section{Discussion}

In Figure 4 the four basic types of shale-clast-rich turbidites and slurried beds are plotted against some of the parameters which are thought to control facies, that is, the volume of flows and amount of mud incorporated versus the distance traveled from the point of mud intake. The competence of gravity flow and its capacity to erode the seafloor are to some extent positively correlated with the volume of the flow itself. High-volume turbidity currents are expected to be more effective in eroding and ripping up soft mud clasts. Unconsolidated clay lumps, once incorporated into flows, are rapidly abraded, contributing to the clay content of the suspension. Incorporation of clay increase viscoscity, which tends to inhibit the onset of turbulence and promotes the change from turbulent highly viscous laminar flow conditions that is, from turbidity currents to debris flows (Fisher, 1971; Hampton, 1972). Clay, even in minor amounts, has a "surprising stabilizing effect on the flows" (Hampton, 1972).

If the amount of mud is high compared to the volume of flow, turbidity currents may evolve entirely into 


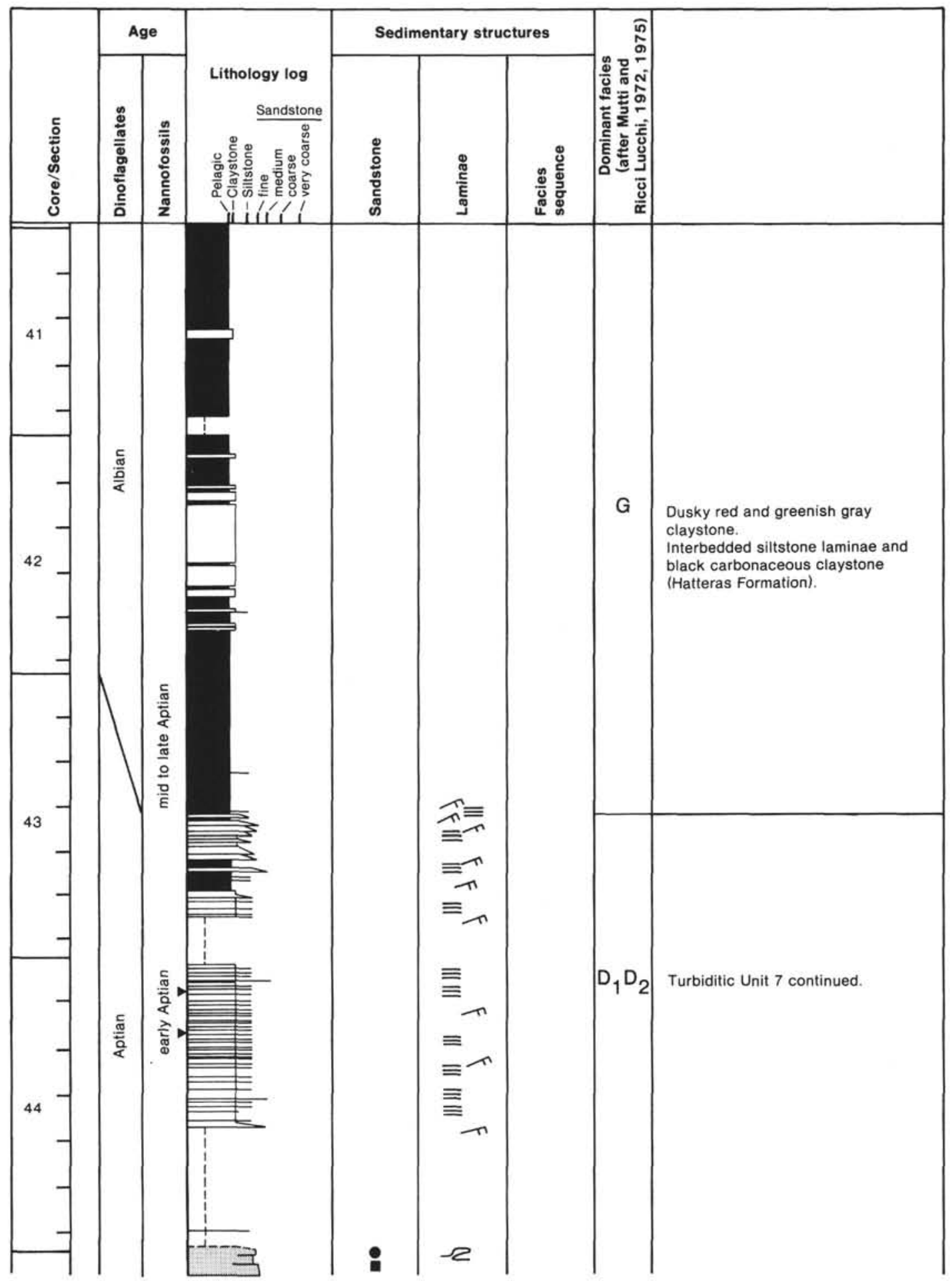

Figure 3. Lithofacies log of the upper Blake-Bahama Formation (lithologic Unit VA) at Site 603 . The width of the individual turbidite beds varies according to grain size.

debris flows, and thus disorganized type 1 beds may be deposited, close to the source (point of mud intake) (Fig. 4, upper left). As motion proceeds and dilution increases, clasts are sorted toward the top of the flowing suspension because of buoyancy effects (Mutti and Nilsen, 1981), and type 2 beds are deposited (Fig. 4, upper middle). Thick, wavy laminae probably indicate the onset of laminar flow conditions, whereas convolute bedding and soft-sediment deformations are probably produced by dewatering. (Convolute laminations in thick, type 1 beds may also be the result of visco-plastic deformation.) As distance increases, shale clasts are totally abraded and type 3 beds are formed (Fig. 4, upper right). No substantial loss of clayey sediments is expected to have oc- 


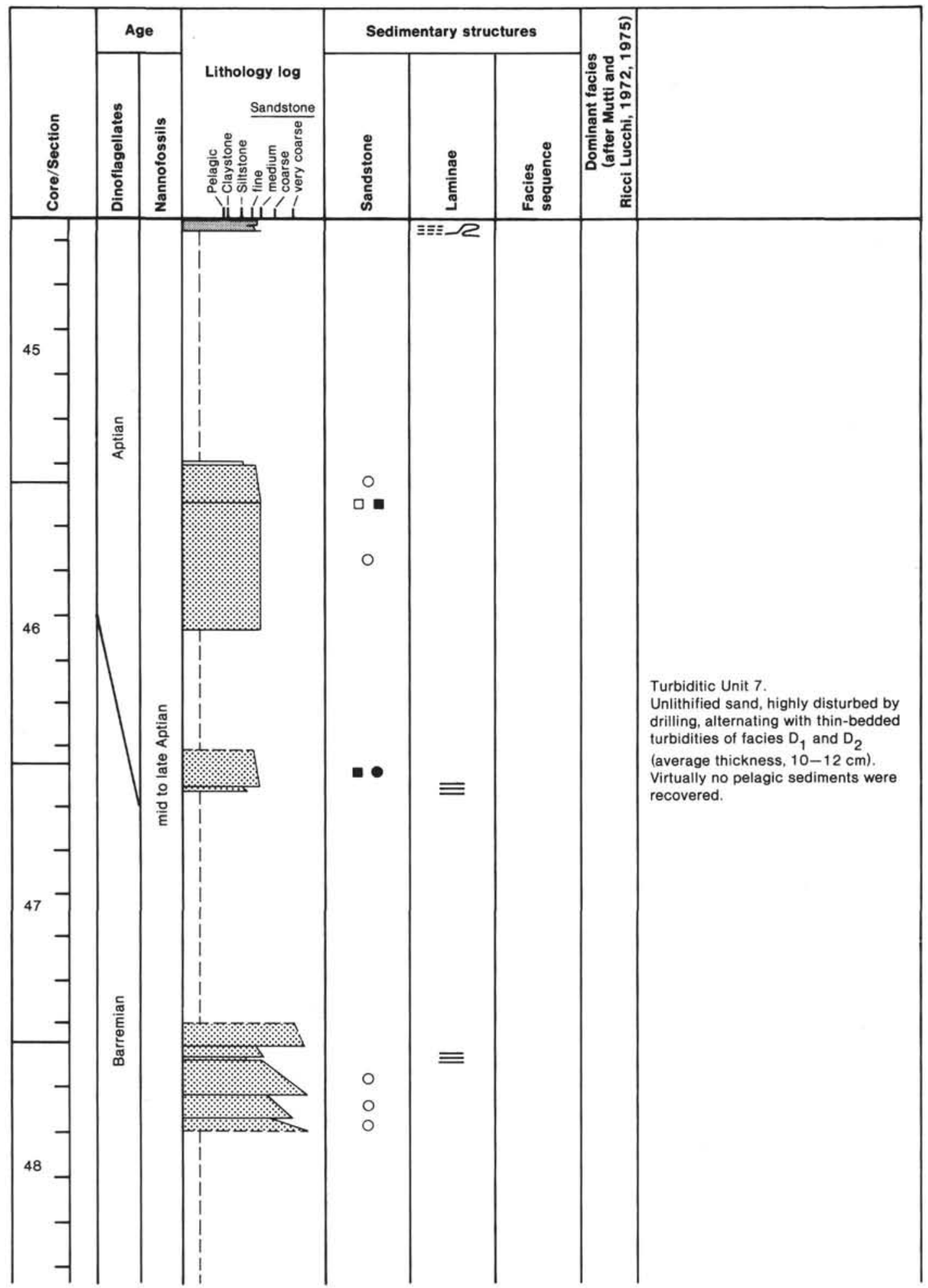

Figure 3 (continued).

curred during motion, because highly viscous flows are inefficient in promoting turbulence. Because of the persistently high clay content, such flows are not expected to have had high mobility; thus type 1 to type 3 beds are presumed to have a limited areal extent and flattened mound shape.

\section{Sandstone-Claystone Turbidites of Facies C and D (D1, D2 and D3)}

Classical turbidites displaying a recognizable Bouma sequence are present from Cores 603B-52 through 603B67 (Fig. 3). Sandstone beds which have a complete Bouma 


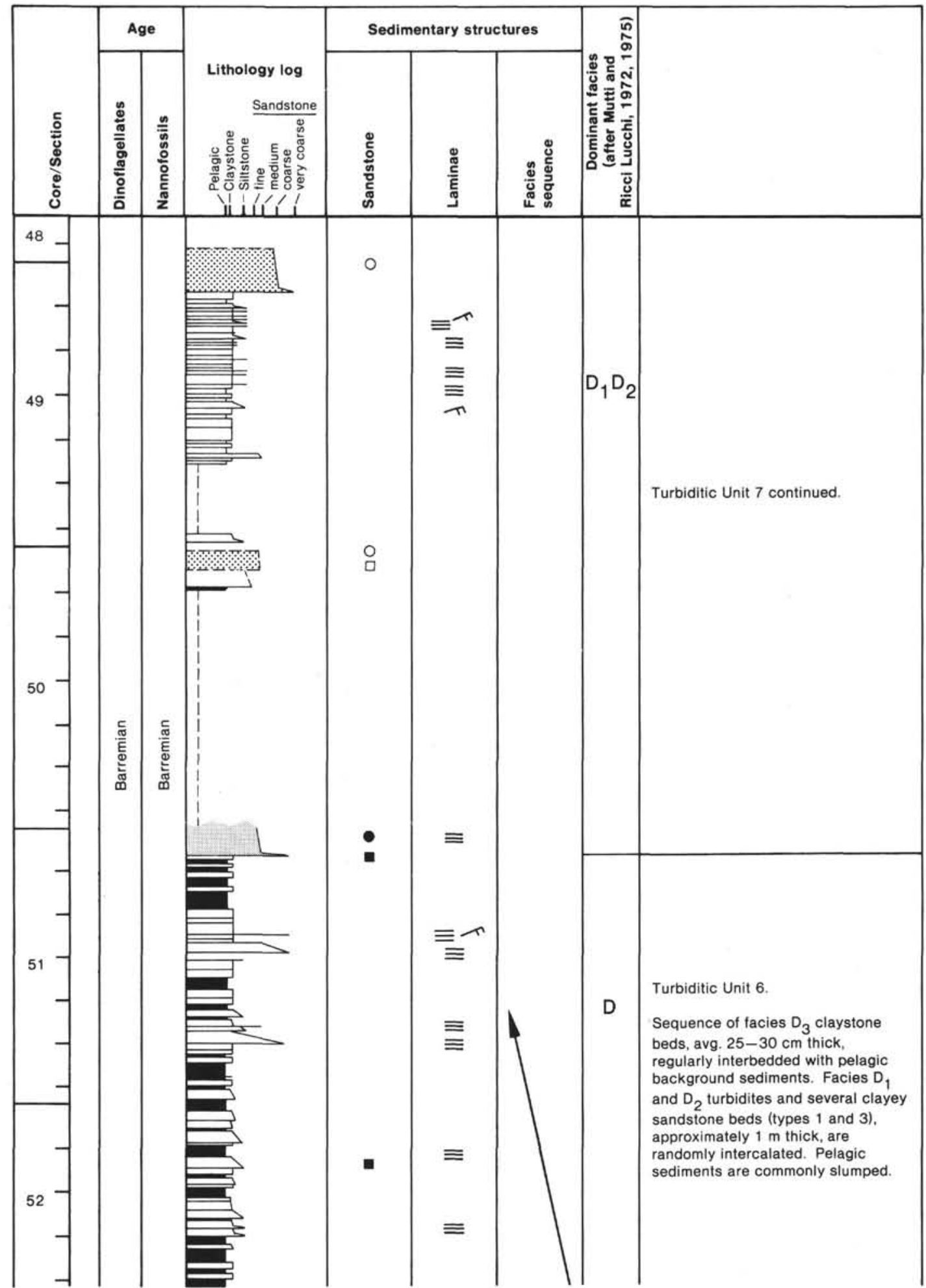

Figure 3 (continued).

sequence, inclusive of the lower massive division a $\left(\mathrm{T}_{\mathrm{a}-\mathrm{b}}\right.$ and $\mathrm{T}_{\mathrm{a}-\mathrm{c}}$; facies $\mathrm{C}$ ), are uncommon (Plate 8, Fig. 1; Plate 18, Fig. 1, and Plate 13, Fig. 1). The beds average 30 to $40 \mathrm{~cm}$ thick, rarely exceeding $70 \mathrm{~cm}$, and the coarsest fraction, on average is medium sand. A black turbiditic claystone layer $\left(T_{e}\right), 2-3$ to $10 \mathrm{~cm}$ thick, normally occurs at the top of the sandstone (sand:shale ratio is much greater than 1).

Sandstone-claystone couplets displaying a Bouma sequence missing the base $\left(T_{b-e}\right.$ and $T_{b / e}$, rarely $T_{c-e}, T_{d-e}$, facies $D_{1}$ and $D_{2}$ ), are common from Sections 603B-67-1 to 603B-44-3 and are dominant at certain intervals (e.g., 


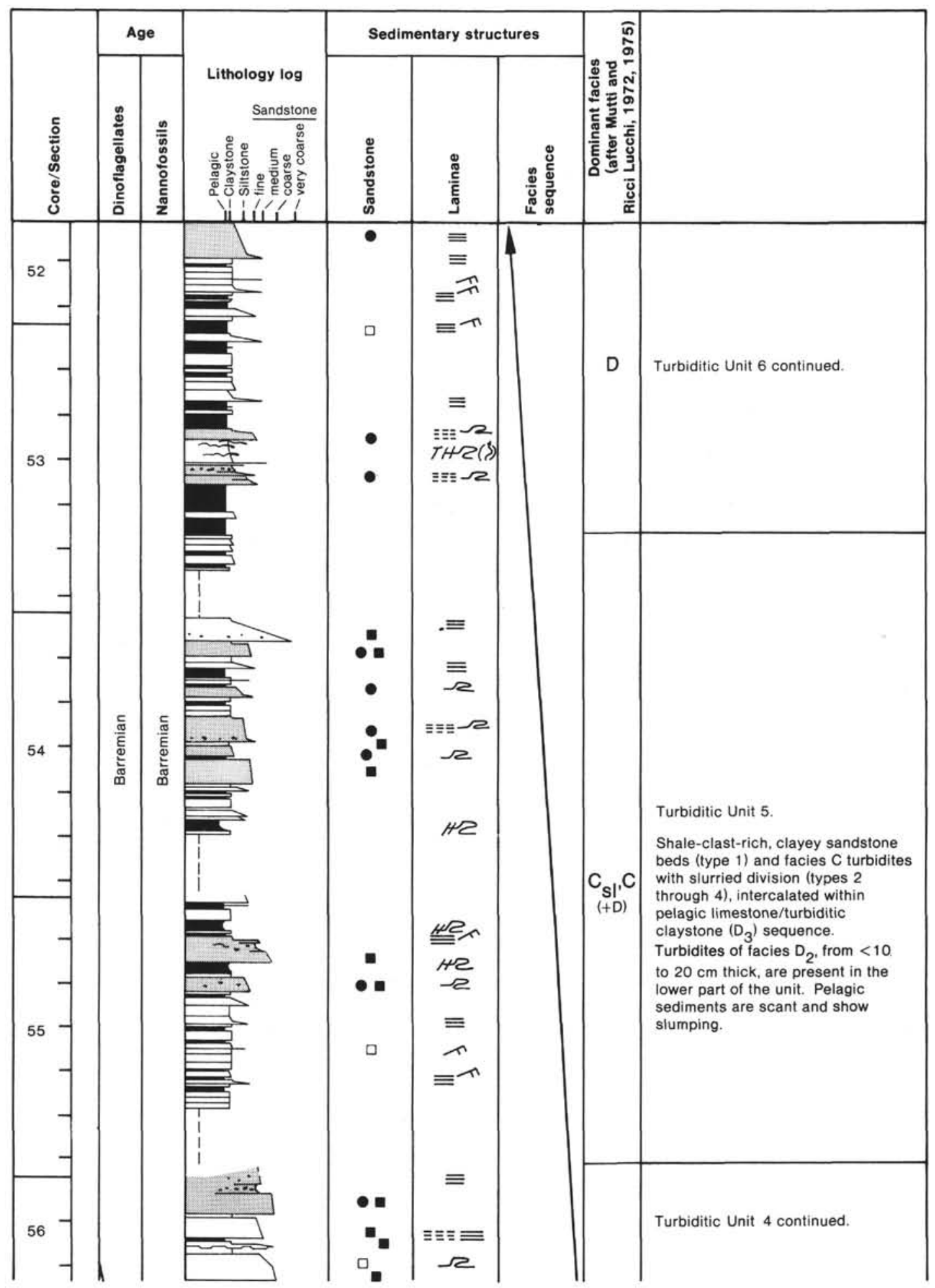

Figure 3 (continued).

Cores 603B-44 and -49, Fig. 3; Plate 7 and Plate 15, Fig. 2). Facies $D_{1}$ beds are composed mainly of sandsized sediment (sand:shale ratio 1 to much greater than 1); their coarsest fraction averages medium to fine sand. Facies $\mathrm{D}_{2}$ beds are composed chiefly of black silty claystones rich in organic matter, usually with a thin horizon of siltstone or very fine sandstone at the base (sand: shale ratio less than 1 to much less than 1 ). Both types vary in thickness from 10 to $20 \mathrm{~cm}$; values from 25 and up to $40 \mathrm{~cm}$ are less common. Sandstone beds are commonly cemented by calcite at the base (Plate 3, Fig. 5; Plate 5). Grain size and bed thickness are positively correlated in facies $C, D_{1}$, and $D_{2}$ turbidites.

Black, organic-matter-rich (silty) claystone beds, massive or faintly laminated at the base $\left(T_{e}\right.$; facies $\left.D_{3}\right)$, represent a sort of background sedimentation throughout 


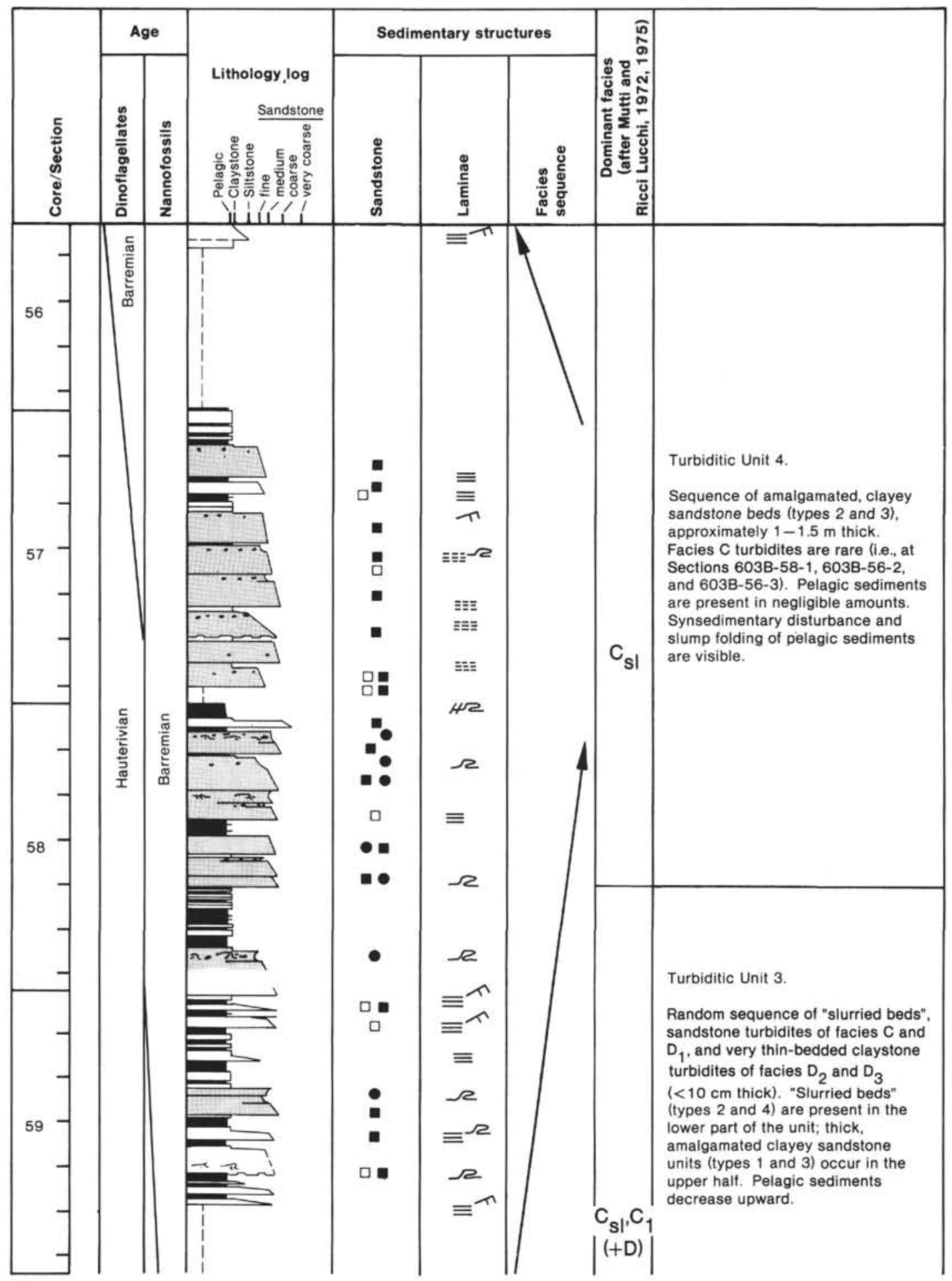

Figure 3 (continued).

the succession, from Sections 603B-76-1, to 603B-44-1. Claystone beds are sedimentologically identical to the top layers of sandstone turbidites. Terrestrial organic matter is present in amounts up to $30 \%$. Thicknesses vary from $2-3$ to $80 \mathrm{~cm}$; the average is 20 to $40 \mathrm{~cm}$, decreasing up-section. Black claystones are also present from Core 603B-44 upward. They are sedimentologically similar to those of the Blake-Bahama Formation, although their organic matter is more marine in character (Meyers et al., this volume), and characterize the "black carbonaceous claystone" Unit IV (Hatteras Formation), of Albian age, at this site.

\section{Slumped Beds and Synsedimentary Deformations}

Pelagic sediments show synsedimentary deformations in the interval between Sections 603B-58-1 and 603B53-3. In all these cases slump folding is observed in either the laminated marl or the bioturbated chalk. Soft- 


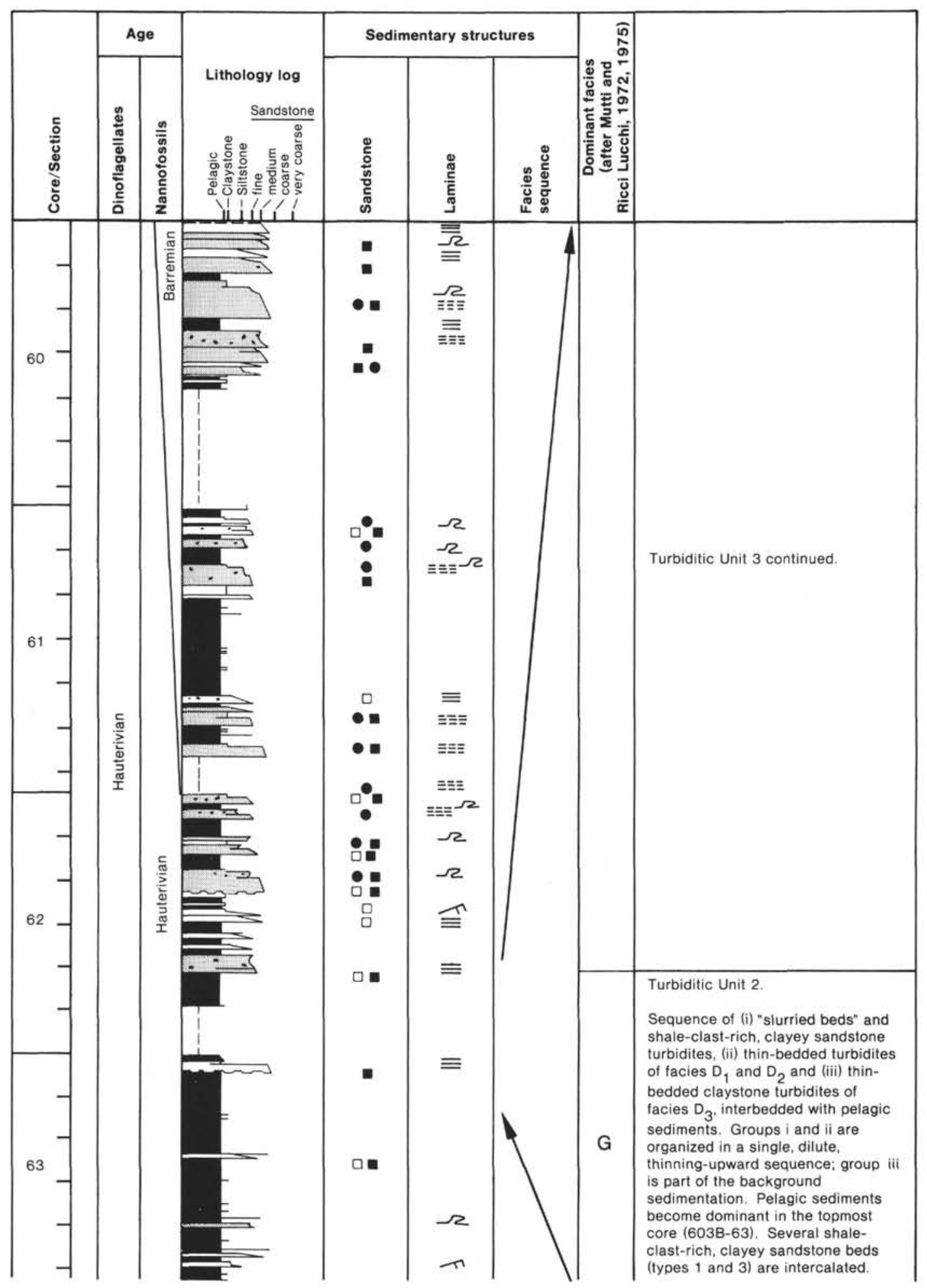

Figure 3 (continued).

sediment deformation seems to be less common in the black claystones, although it is certainly less easy to detect. No X-radiographs have been performed because shipboard sampling was inadequate; furthermore, shipboard radiographs were unsuccessful. At $603 \mathrm{~B}-60-3,11 \mathrm{~cm}$, a small-scale, hooklike isoclinal fold was observed below a sandstone turbidite (Plate 13, Fig. 1). Such a structure is interpreted as a drag effect on soft sediments caused by a suspension flowing over it.

Slumped horizons are usually less than a meter thick and show tight, disrupted isoclinal folding. Folded bedding surfaces can be smooth; more frequently, they show 


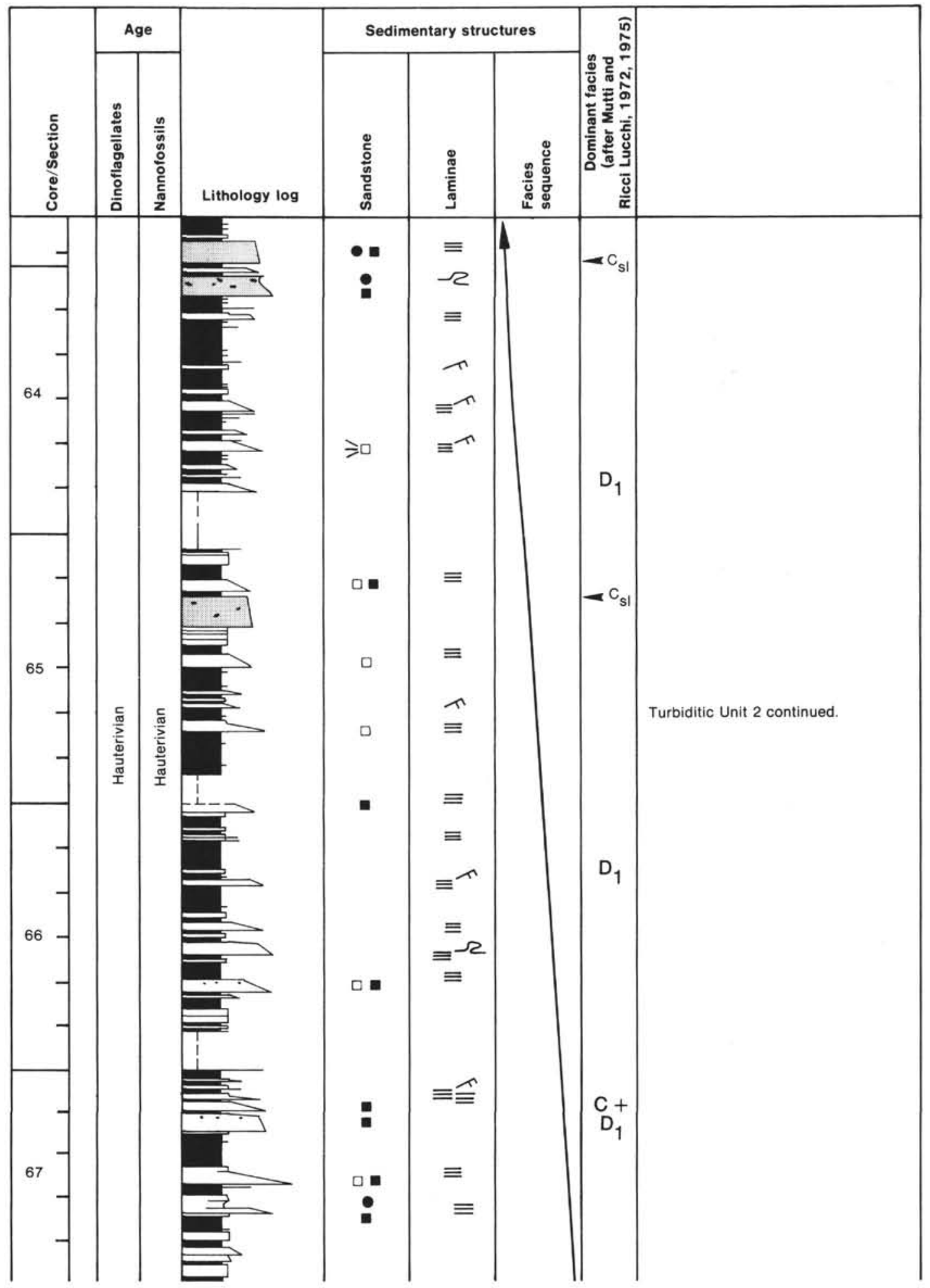

Figure 3 (continued).

extensive microfaulting and crenulation (Plate 10, Fig. 1) depending upon the degree of induration of the sediment at the time it was deformed. Crenulation of bedding planes is interpreted as being derived from a combination of plastic and brittle deformation, along shearing bedding planes, in partially lithified, carbonate-rich sediments.
Composition of Turbidites and Intercalated Pelagic Sediments

Data on the composition of the Lower Cretaceous turbidites between Cores 603B-36 (Cenomanian) and 603B-73 (Valanginian) are compiled in Tables 1 and 2. These tables summarize our qualitative and semiquanti- 


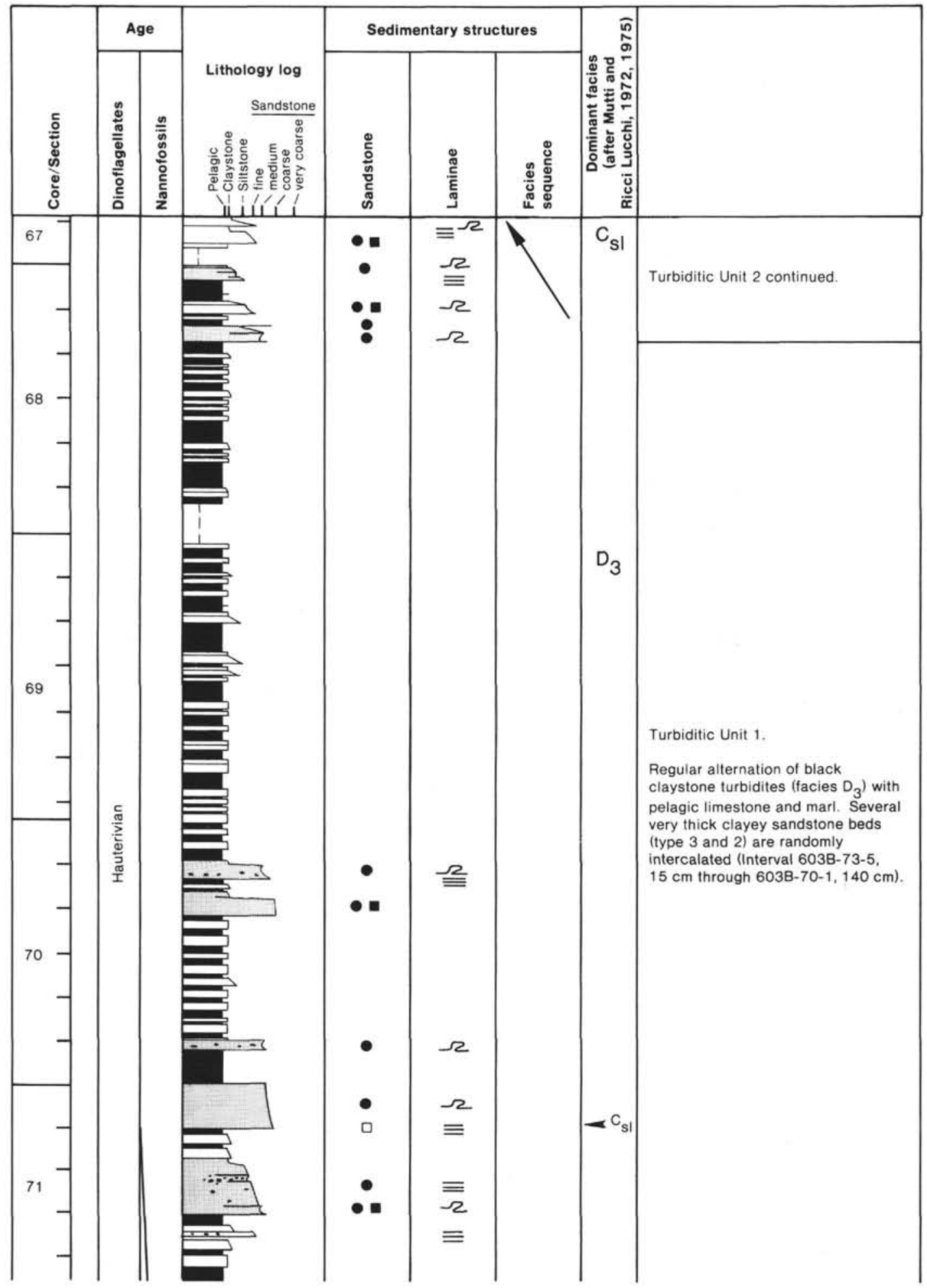

Figure 3 (continued).

tative results from thin-section and X-ray diffraction analysis of 40 samples, subdivided into three groups according to grain size and turbidite facies.

Facies $C$ turbidites are characterized by dominant quartz $(25-45 \%)$ and feldspar (1-5\%), and by plant debris in amounts as great as $5 \%$. Clay content is very low (5 to $10 \%$ ) and calcite cement is present in all samples.
The medium- to coarse-grained sandstones (mean about $100-300 \mu \mathrm{m}$, maximum grain size $300-1000 \mu \mathrm{m}$ ) are moderately to very poorly sorted. Sandstone grains are angular.

Thick-bedded sandstones bearing shale clasts and slurried beds have all been placed in a single group, because their composition is fairly uniform (Plate 2, Figs. 3, 4, 


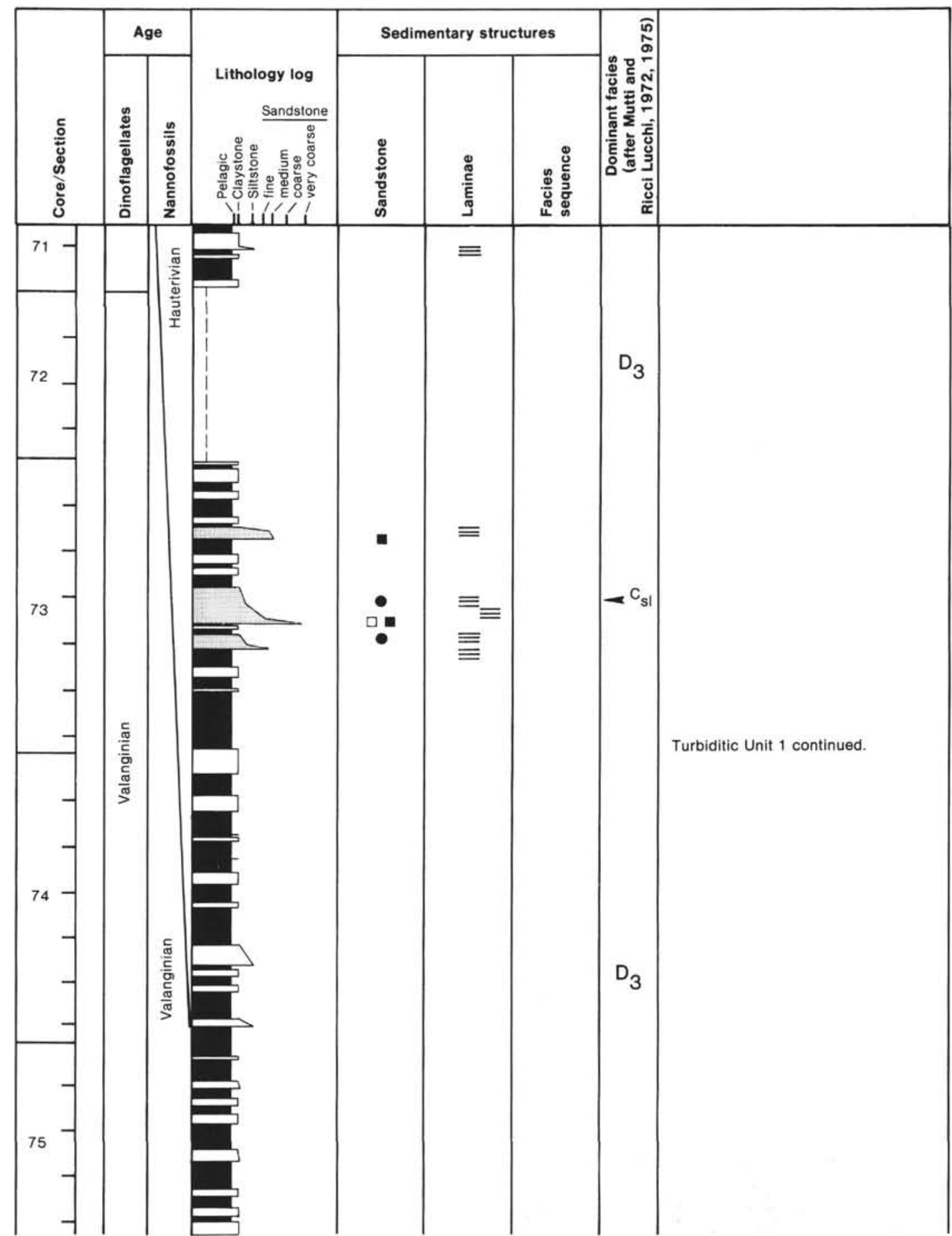

Figure 3 (continued).

and 5). The maximum grain size is $400-1000 \mu \mathrm{m}$. The poorly to very poorly sorted sandstones are commonly polymodal, with modes around $30-60 \mu \mathrm{m}, 60-120 \mu \mathrm{m}$, and $200-500 \mu \mathrm{m}$. Major detrital components are quartz (20-50\%), feldspar (traces to $10 \%$ ), and muscovite (3$10 \%$ ). Particularly remarkable is the occurrence of dolomicrite (or siderite?) pebbles, a few millimeters across, in amounts up to $5 \%$ (Plate 5, Fig. 1). Terrestrial plant debris (Plate 4, Figs. 3 and 4) is present in amounts as much as $7 \%$. Clay content is high (40-55\%), dropping to $0-5 \%$ if the basal parts of turbidites are cemented by calcite (Plate 5, Figs. 2 and 3). Common to rare constituents are pyrite (1-3\%), rock (shale) fragments, glauconite, fish debris, mollusk fragments (Plate 4, Fig. 1) and pyritized radiolarians (Plate 5, Fig. 4).

Facies $D_{1}$ and $D_{2}$ turbidites are similar in composition to coarser facies $C$, whereas silt-sized layers of the Hatteras Formation (lithostratigraphic Unit IV, Cores 

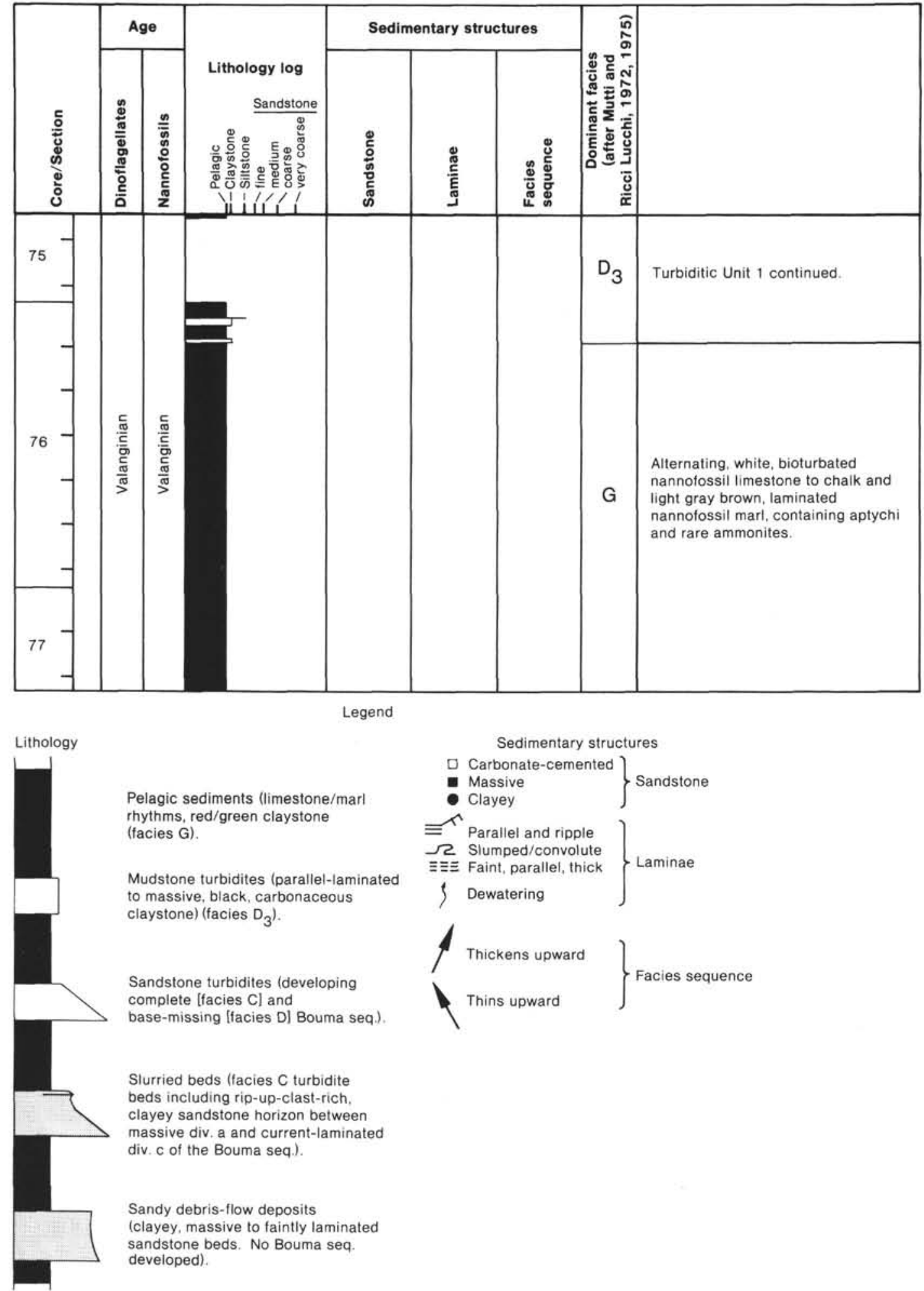

Figure 3 (continued).

603B-36 through-42) show enrichment of quartz (up to $60 \%$ ), mica (up to $15 \%$ ), glauconite (2-5\%), and pyrite $(10 \%)$. In general, these turbidites contain $30-60 \%$ quartz, up to $8 \%$ feldspar, $5-15 \%$ mica, and $2-10 \%$ plant material (Plate 3, Figs. 3-4). If they are calcite-cemented (40$55 \%$ ), they contain only $0-7 \%$ clayey matrix (Plate 3 ,
Fig. 5). In general, these sand layers are fine-grained (maximum grain size $120-300 \mu \mathrm{m}$; mean about $30-200 \mu \mathrm{m}$ ) and moderately to well-sorted. $\mathrm{C}_{\text {org }}$ content is $0.3-2 \%$; the $\mathrm{CaCO}_{3}$ content of those layers which are not calcitecemented is only $0.5-5 \%$. One single ripple-laminated bed in Sample 603B-43-5, 63-72 $\mathrm{cm}$ has an anomalous 
Table 1. Composition, texture, and XRD data (H. Rösch, Hannover), with $\mathrm{CaCO}_{3} / \mathrm{C}_{\text {org }}$ values of turbiditic lithotypes of the Blake-Bahama Formation (BGR data), Hole 603B.

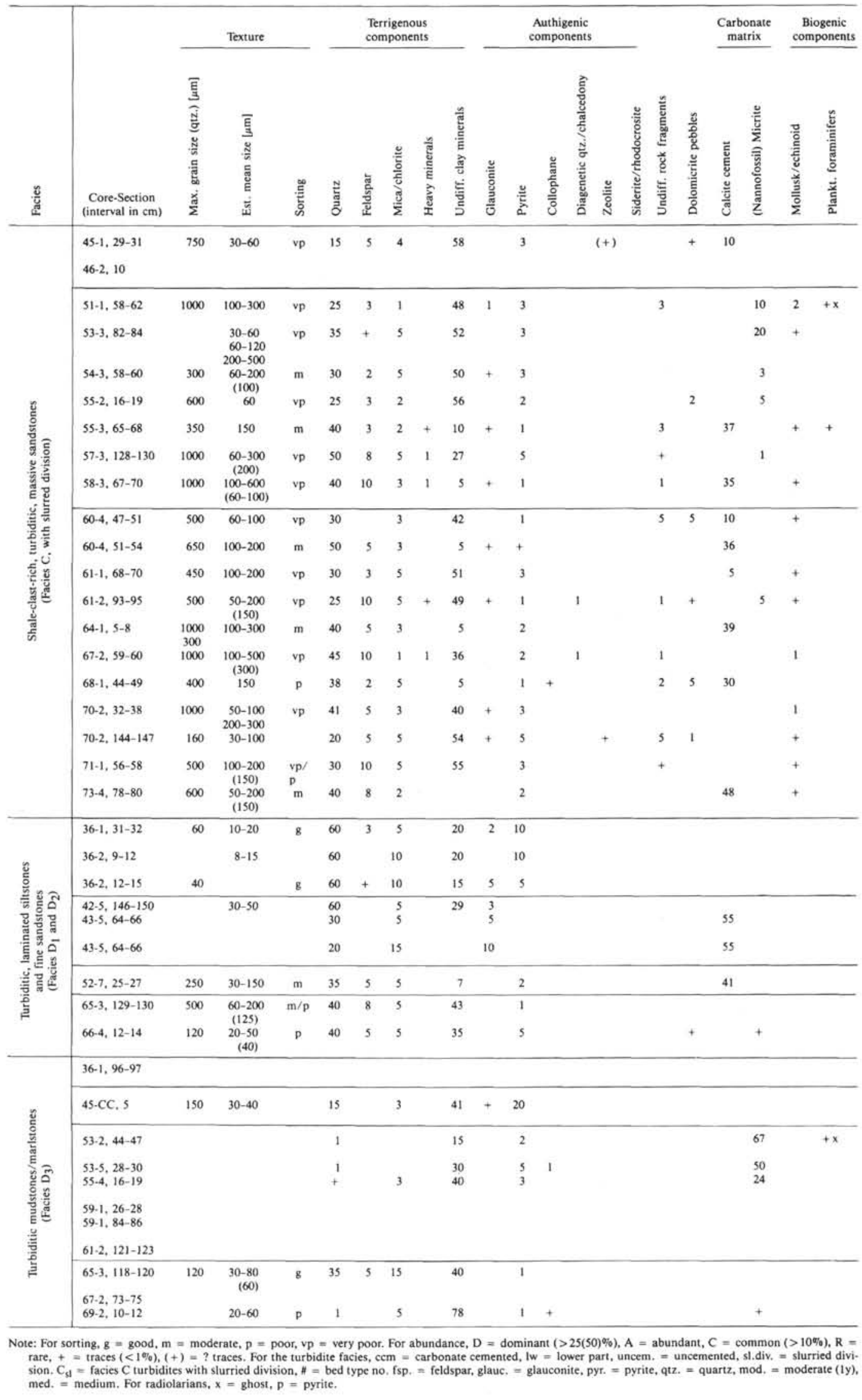


Table 1 (continued).

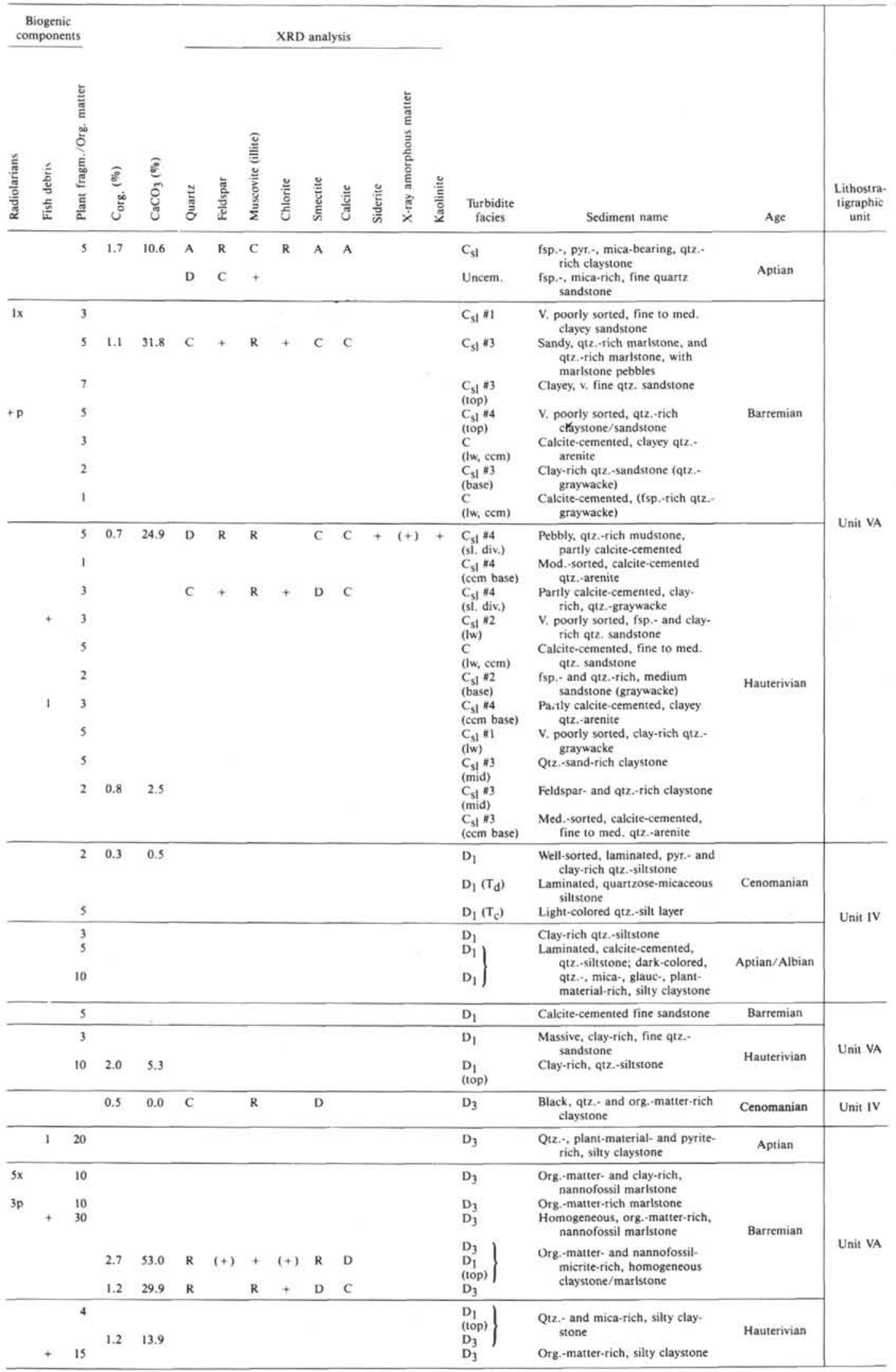




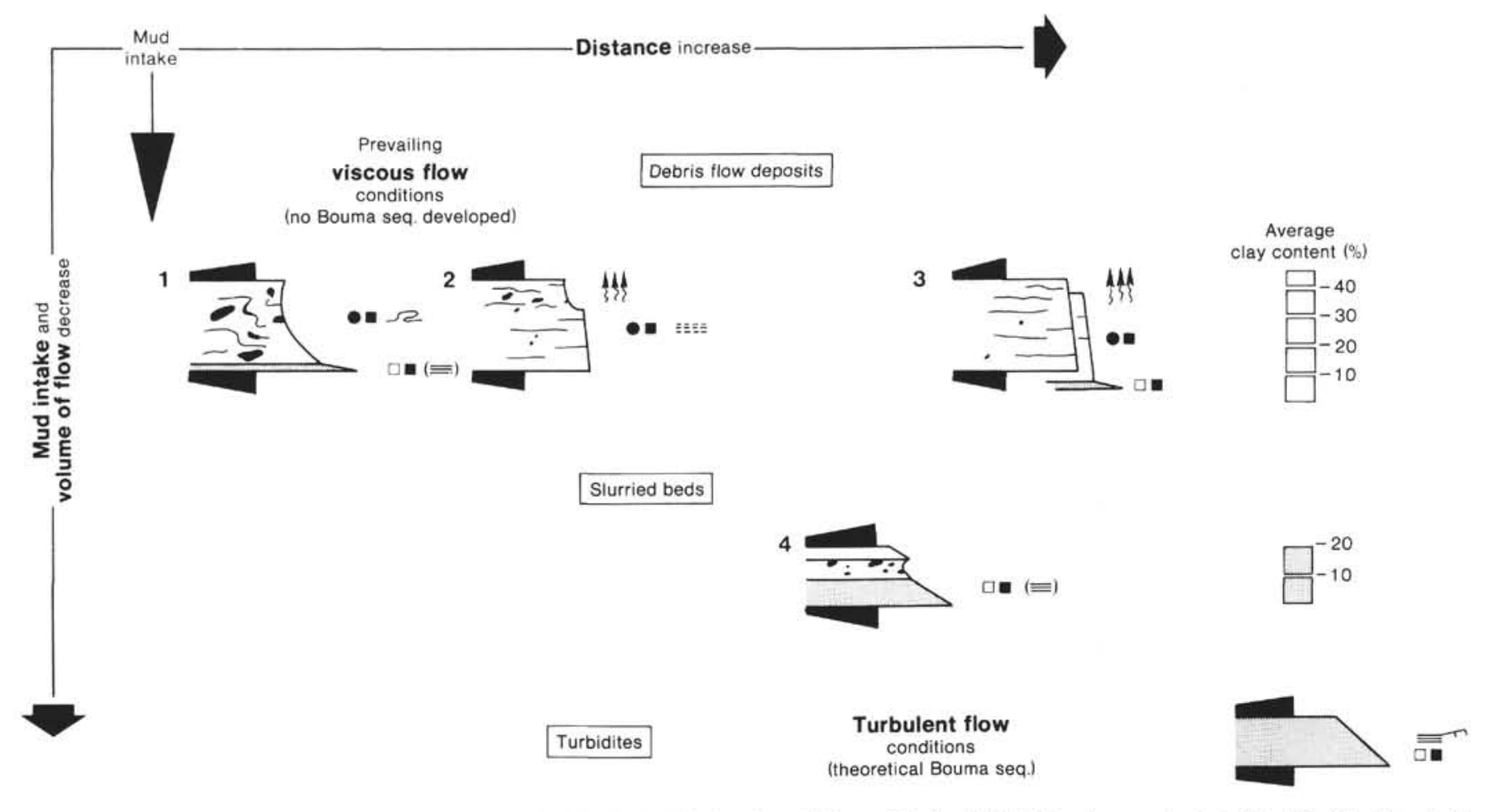

Figure 4. Basic types of shale-clast-rich beds and "slurried beds" (facies C turbidites with slurried division) recognized at Site 603 . The four bed types are plotted against parameters which are thought to control their facies: volume of flow and amount of incorporated mud versus distance of travel from the point of mud intake. Types 1 to 3 are disorganized, clayey sandstone beds in which the Bouma sequence is largely not applicable. Shale clasts are randomly distributed in type 1 beds, are concentrated toward the top of type 2 beds and are virtually absent in type 3 beds. Type 4 beds are commonly thinner layers in which the chaotic, clayey sandstone horizon is more consistently organized with respect to the Bouma sequence, being sandwiched between a massive division a (sometimes the laminated division b) and the claystone top layer. Ordinary turbidites are represented in the lower right. Symbols as in Fig. 3 legend.

Table 2. Generalized composition of different types of turbidite facies, in percent.

\begin{tabular}{|c|c|c|c|c|}
\hline Mineral phase & $\mathrm{C}$ & $\mathrm{C}_{\mathrm{sl}}$ & $D_{1}-D_{2}$ & $\mathrm{D}_{3}{ }^{\mathrm{a}}$ \\
\hline Quartz & 40 & $25-50$ & $35-40$ & $1-15(35)$ \\
\hline Feldspar & $3-10$ & $2-8(10)$ & $5-8$ & $0(5)$ \\
\hline Mica & $2-3$ & $2-5$ & 5 & $0-3(15)$ \\
\hline Undiff. clay & $5-10$ & $0-5(\mathrm{ccm}), 36-58$ & $7(\mathrm{ccm}), 35$ & (15) $30-40$ \\
\hline Spar. calcite & $30-40(\mathrm{ccm})$ & $36-48(\mathrm{ccm}), 0-5$ & $41(\mathrm{ccm}),-$ & \\
\hline Undiff. rock fragments & $1-3$ & $\mathrm{~T}-5$ & & \\
\hline Dolomicrite pebbles & & $\mathrm{T}-5$ & $\mathrm{~T}$ & \\
\hline Heavy minerals & $T-1$ & & & \\
\hline Pyrite & $1-2$ & $\mathrm{~T}-3$ & $1-5$ & $1-5(20)$ \\
\hline Pyr. radiolarians & & $\mathrm{T}$ & & \\
\hline Glauconite & $\mathrm{T}$ & $\mathrm{T}$ & $\mathrm{T}$ & $\mathbf{T}$ \\
\hline Org. matter/plants & $1-5$ & $1-7$ & $3-10$ & $5-30$ \\
\hline Fish debris & & $\mathrm{T}$ & & $T-1$ \\
\hline Mollusk shells & $\mathrm{T}$ & $\mathrm{T}$ & & \\
\hline Nannomicrite & & $0-5(10)$ & $\mathrm{T}$ & $0-25(50-67)$ \\
\hline Rads. + diatoms & & & & $\mathrm{T}-5$ \\
\hline $\mathrm{C}_{\text {org }}$ & & & & $1.2-2.7$ \\
\hline
\end{tabular}

Note: $\mathrm{C}_{\mathrm{sl}}=$ facies $\mathrm{C}$ turbidites with slurred division and/or thick, structureless sandstone beds. $\mathrm{ccm}=$ carbonate-cemented. $\mathrm{T}=$ trace.

${ }^{a}$ Extreme values given in parentheses before (min.) and after (max.) the ranges.

composition showing enrichment in mica, glauconite, and plant fragments-possibly indicative of mechanical sorting.

Facies $D_{3}$ turbiditic claystones contain much less detrital mineral (1-10\% quartz, traces to $5 \%$ feldspar, 3$15 \%$ mica). They consist of varying proportions $(15-80 \%)$ of undifferentiated clay minerals (abundant smectite, common kaolinite, traces of chlorite) and nannomicrite. Py- rite (1-5\%, maximum $20 \%$ ), pyritized radiolarians (3$5 \%$ ), and fine-grained plant material (3-10\%, maximum $30 \%$ ) are also very common (Plate 5, Fig. 5).

Scanning electron micrographs (Plate 6, Figs. 3 and 4) show that the coccoliths and rhabdoliths are exceptionally well preserved. Rapid burial after redeposition probably protected these particles from the corrosion typically observed in slowly deposited pelagic sediments of the outer rise.

The maximum grain size of these clay- to silt-sized turbidites is $120-180 \mu \mathrm{m}$. $\mathrm{C}_{\text {org }}$ contents range from 0.5 to $2.7 \%, \mathrm{CaCO}_{3}$ contents from about 14 to $53 \%$.

Pelagic sediments. Bioturbated, homogeneous, white limestones, cyclically alternating with laminated brown marls, are the pelagic background sediment between the turbidites. The white limestones are composed of nannofossil micrite and contain calcified radiolarians in amounts as great as $25 \%$. Quartz, mica, clay minerals, and organic matter are present in amounts ranging from traces up to $5 \%$. The laminated brown marlstones have a $\mathrm{CaCO}_{3}$ content of $30-80 \%$ and comparatively high organic carbon values $\left(0.5-3 \% \mathrm{C}_{\mathrm{org}}\right)$. Montmorillonite is the dominant mineral; chlorite and kaolinite are present in trace amounts. Fish debris (1-3\%) and plant material, up to $10 \%$ (Plate 1, Figs. 3 and 4 ) are other common constituents. Radiolarians ( 3 to $10 \%$ ) are commonly calcitized and pyritized. 
A detailed account of the composition of the lower Cretaceous pelagic sediments is given by Ogg et al., (this volume).

\section{Age, Sedimentation Rates, and Frequency of Turbidity Currents}

Age determination of the Lower Cretaceous turbiditic succession is based chiefly on calcareous nannofossils and dinoflagellates (see Biostratigraphy section in the Site 603 chapter; Habib and Drugg, this volume). Ages and turbiditic units referred to in the text are indicated in the same figure. Dinoflagellate dates are slightly older, but stage boundaries are apparently better defined. No Aptian-Albian boundary could be defined by nannofossils, because only carbonate-free sediments occur above Section 603B-44-1, $107 \mathrm{~cm}$. An accurate early Aptian date has, however, been provided by nannofossil assemblages in four samples located between Sections 603B$44-1,107 \mathrm{~cm}$ and 603B-44-2, $137 \mathrm{~cm}$.

According to these data, redeposition of black carbonaceous clayey sediments at Site 603 began in the late Valanginian, whereas redeposition of substantial sand occurred in Hauterivian and Barremian time. Sandstone Unit 4 is (late Hauterivian-)Barremian in age. The thick, uncemented sand Unit 7, which has autochthonous pelagic sediments of middle to late Aptian age above it, is presumably early Aptian in age, whereas the base of the unit is supposed to be Barremian. According to dinoflagellate dates, the top of the Blake-Bahama Formation virtually coincides with the Aptian-Albian boundary.

Sedimentation Rates. Using dinoflagellate dates (Habib and Drugg, this volume), we calculated sedimenta- tion rates uncorrected for compaction. Tentative results are listed in Table 3. The geologic time scale used in that of Harland et al. (1982).

In the Valanginian, low sedimentation rates $(\sim 10.2 \mathrm{~m} /$ Ma) reflect pelagic deposition, whereas in the Hauterivian values jumped to approximately $22.9 \mathrm{~m} / \mathrm{Ma}$ as turbidite deposition began. Rates of pelagic deposition in the same interval, once the succession was "compacted" for turbidites, average $9.6 \mathrm{~m} / \mathrm{Ma}$. Curiously, in the Barremian-Aptian interval, average values drop to $11.0 \mathrm{~m} /$ $\mathrm{Ma}$ and the figure becomes even lower, $8.8 \mathrm{~m} / \mathrm{Ma}$ (close to rates of purely pelagic deposition), if the unconsolidated sand (turbiditic Unit 7, Fig. 3) is considered alone.

Sedimentation rates for the Valanginian and Hauterivian are consistent with pelagic and turbiditic sedimentation, but are anomalously low once we consider the upper part of the succession, which comprises most of the sand. Since it is unlikely that turbiditic sands were deposited at rates comparable to those of pelagic oozes, we have to postulate either a dominant pelagic contribution in the unrecovered portions of Cores 603B-45 through -50 , or a major stratigraphic gap in the succession. The second possibility is preferred, although it is not confirmed by biostratigraphic data. Reflection Horizon $\beta$, coinciding with the base of turbiditic Unit 7, is in fact a regional unconformity that locally shows truncating character. Horizon $\beta$ might therefore represent a stratigraphic gap of regional significance.

The location of the Barremian/Aptian boundary, drawn at a sub-bottom depth of $1241 \mathrm{~m}$ between Cores $603 \mathrm{~B}-46$ and -47 , is questionable because it falls in the middle of redeposited sands (Sections 603B-45-1, $0 \mathrm{~cm}$

Table 3. Bulk sedimentation rates of the upper Blake-Bahama Formation (lithostratigraphic Unit VA).

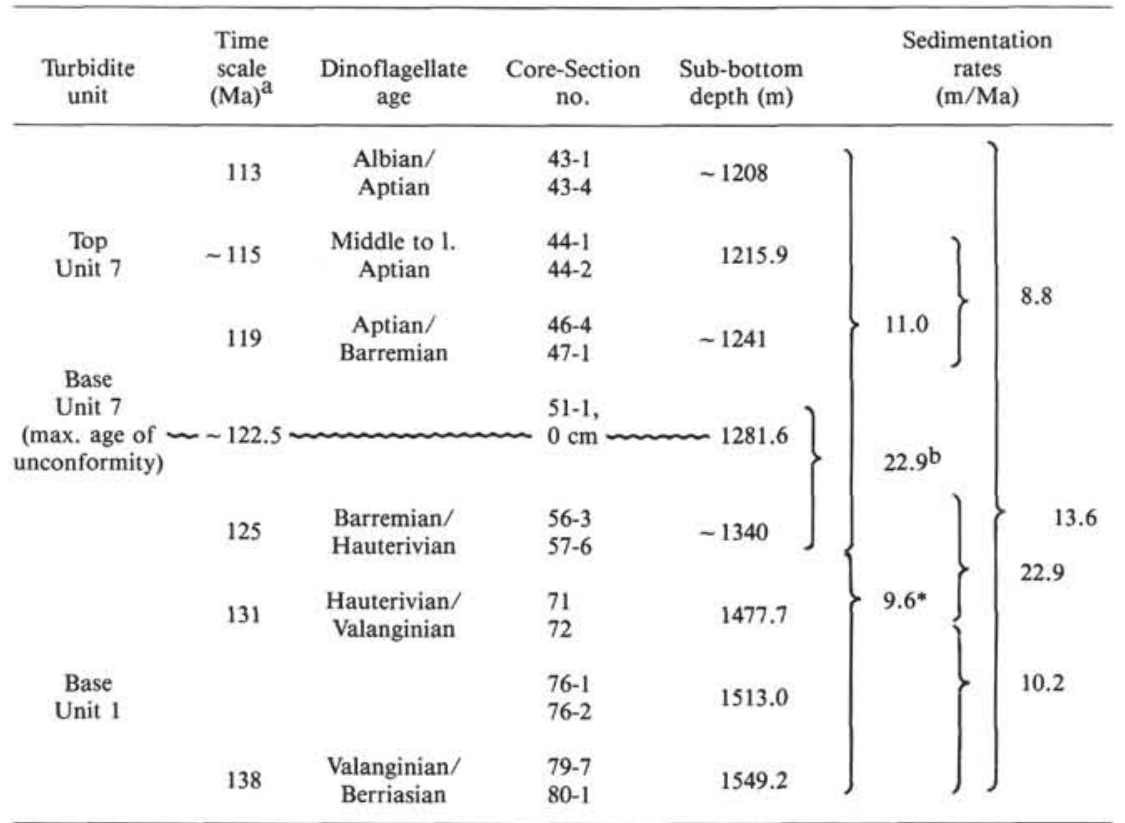

Note: * Accumulation rates for pelagic sediments without turbidites.

a time scale used after Harland et al. (1982).

$\mathrm{b}$ The maximum age of unconformity $\beta$ comes out as $2.5 \mathrm{Ma}$ younger than the age of the Hauterivian/ Barremian boundary, if one assumes that the Hauterivian sedimentation rates of $22.9 \mathrm{~m} / \mathrm{Ma}$ persist into the earliest Barremian, resulting in a lowermost Barremian section of $58.4 \mathrm{~m}$. 
through $603-48-1,110 \mathrm{~cm}$ ). Floral assemblages in the vicinity of this boundary have been reworked (Habib and Drugg, this volume). Therefore, this chronostratigraphic boundary has not been taken into account in our calculation. We speculate that emplacement of the sands of turbiditic Unit 7 might not have begun in the Barremian, but significantly later (Aptian?).

No quantitative study was made of the amount of interbedded pelagic sediments. However, the average thickness of pelagic interbeds occurring in the lower succession (turbiditic Units 1 through 3,5, and 6) indicates that most of the siltstone and sandstone turbidites were deposited at a frequency of one event every 30,000 to 60,000 yr. Amalgamated sands of Unit 4 were probably deposited at higher rates. These figures are at least one order of magnitude lower than those of most modern and ancient fans (Stow et al., 1983/84).

\section{Seismic Characteristics of the Turbiditic Sequence}

Figure 5B illustrates a segment of the Conrad 2101-77 multichannel seismic profile, at the seaward end of the New Jersey Transect. The seismic trackline map and the stratigraphic interpretation of Figure 5B are reported in the Site 603 chapter (this volume, Figs. 4 and 30). Seismic reflection horizons drilled at Site 603 , along with their characteristics, are listed in Table 6 of the same section.

DSDP Site 603 is located on the landward edge of the lower continental rise hills, above a pronounced trough in the acoustic basement. This depression, $20 \mathrm{~km}$ wide along the section shown, is bordered by basement swells draped by the Jurassic seismic Horizons $J_{1}$ and $J_{2}$ (Fig. 5B).

$\mathrm{Kb}$ is the deepest seismic reflection horizon drilled at DSDP Site 603 (see Site 603 chapter, this volume), draping basement topography over most of the Conrad 2101-77 profile (Fig. 5B). This reflector was penetrated at a subbottom depth of $1525 \mathrm{~m}$, corresponding to the base of the turbiditic portion of the Blake-Bahama Formation (Jansa et al., 1979; lithostratigraphic Unit VA). The seismic unit below $\mathrm{Kb}$ (lithostratigraphic Unit VB in Hole 603B) is Berriasian-Valanginian in age and is characterized by pelagic deposition. The pelagic signature is confirmed by the draping nature of its internal reflectors. Horizon $\mathrm{Kb}$ is underlined by a few discontinuous, parallel reflectors in the trough area, and truncates the underlying unit at a few local basement highs.

Horizon $\beta$ is a prominent, high-amplitude seismic reflection horizon of regional significance. It coincides with the boundary between the Neocomian limestone of the Blake-Bahama Formation and the overlying argillaceous succession (Hatteras Formation) at many western North Atlantic DSDP sites (Lancelot et al., 1972; Tucholke and Mountain, 1979; Jansa et al., 1979). At Site 603, Horizon $\beta$ has been identified as the base of the unconsolidated sand unit (turbiditic Unit 7; see Seismic Stratigraphy section in the Site 603 chapter, this volume) and was penetrated at the sub-bottom depth of $1265 \mathrm{~m}$, Horizon $\beta$ is conformable over most of the Conrad 2101-77 profile, but is truncating in character at several places over basement highs (Fig. 5B). Above $\beta$, the acoustically trans- parent seismic Unit 6 topped by Reflector Km corresponds partly to the unconsolidated sands of Cores 603B-51 through -44 and partly to the "black carbonaceous claystone" Unit IV (Hatteras Formation). We believe that the unconsolidated sand body probably corresponds to the lowermost layer of seismic Unit 6, showing a bundle of a few discontinuous, parallel reflection horizons.

Horizons $\mathrm{Kb}$ and $\beta$ enclose a stratigraphic interval designated as "reflection Unit 7" in the Seismic Stratigraphy section of the Site 603 chapter (this volume). Reflection Unit 7 corresponds to the turbiditic portion of the Blake-Bahama Formation. Unit 7 is thicker above the basement trough at Site 603, where turbidites were deposited and where there exists a prominent, crenulated, hummocky reflection configuration that changes laterally to a more parallel internal pattern. Reflection Unit 7 thins laterally over basement highs by progressive onlap of internal reflectors onto $\mathrm{Kb}$. Onlap fill proves that turbidite sedimentation was guided by the seafloor topography and that the general distribution of redeposited sediments was controlled by the structure of the basement.

U.S.G.S. multichannel seismic line 25 corresponds to the landward sector of the New Jersey Transect (Fig. 5A), having approximately the same direction as Conrad line 2101-77. U.S.G.S. line 25 terminates about $130 \mathrm{~km}$ seaward of DSDP Sites 604 and 605; a gap in seismic data exists between this point and Conrad line 2101-77 (Fig. 6). Figure 5A shows the location of the Upper JurassicLower Cretaceous shelf edge and the transition to the basin, as interpreted by Klitgord and Grow (1980). Because none of the four DSDP sites drilled along the New Jersey Transect during Leg 93 and 95 penetrated the Lower Cretaceous succession, seismic ties must be made landward, across the paleoshelf edge to the COST B-2 and B-3 wells (Scholle, 1977; Schlee and Grow, 1980; Scholle, 1980). If the correlation between reflection horizons in U.S.G.S. line 25 and the Conrad 2101-77 profiles is correct, then Horizon $\mathrm{Kb}$ on U.S.G.S. line 25 marks the boundary between a disrupted parallel reflection configuration and a more discontinuous, "crenulated" hummocky pattern above, similar to that observed at DSDP Site 603 . Horizon $\mathrm{Kb}$ does not show any truncating character; it is conformable over flat-lying reflectors underneath. The overlying crenulated reflecting unit onlaps onto $\mathrm{Kb}$ landward of Sites 604 and 605 . In Klitgord and Grow's (1980) interpretation, Reflector $\beta$ represents the boundary between an interval with low-amplitude, strong, parallel reflectors and an acoustically transparent zone above. We believe that the transparent unit above $\beta$ may well be the argillaceous succession of the Hatteras Formation, topped by Km, which normally has such a seismic expression. The unit showing a parallel-reflection pattern below $\beta$ in Figure 5A may, instead, compare to the unconsolidated sand unit (turbiditic Unit 7) of Site 603. The turbiditic nature of the seismic unit below B is suggested by its onlap fill geometry and pinch-out toward the slope. In our opinion, there may, therefore, be a discrepancy in the identification of Reflector $\beta$ by Klitgord and Grow (1980) and the Leg 93 shipboard party. In the two profiles of Figure 5, Reflector $\beta$ may in fact 


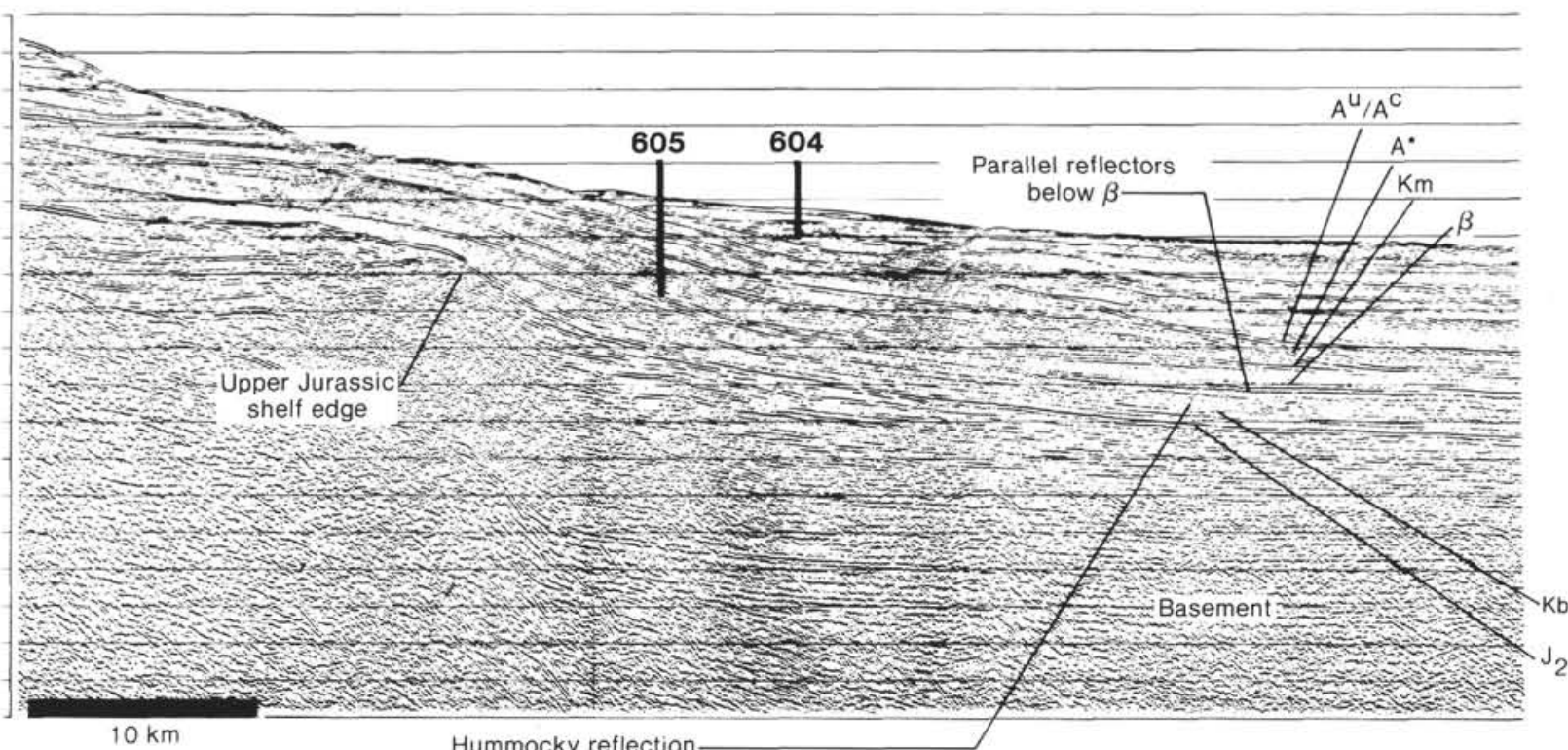

configuration

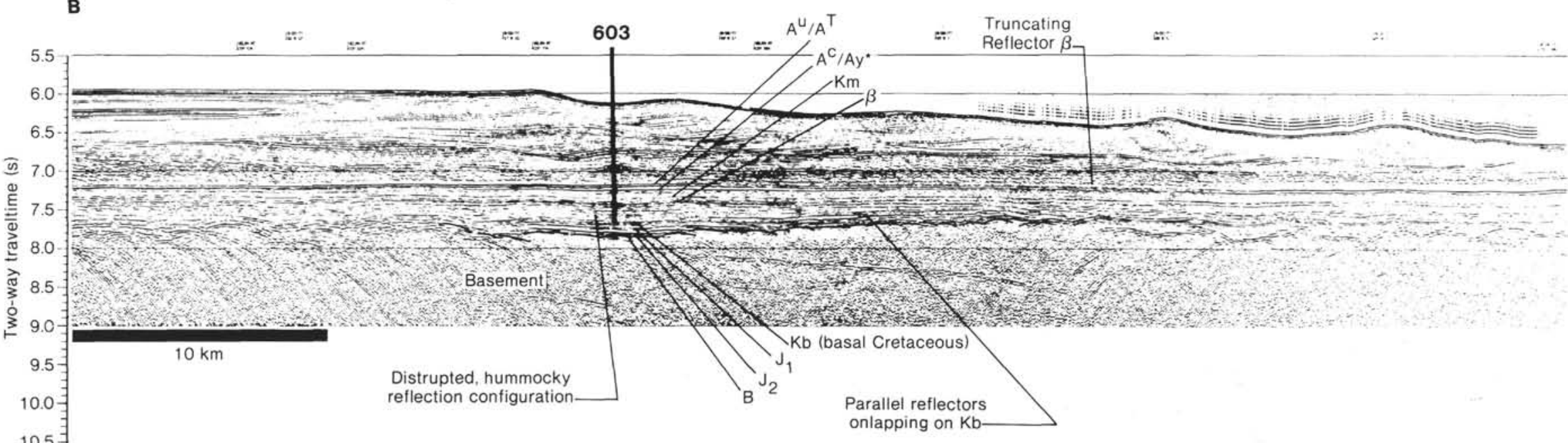

Figure 5. Seismic cross section of the New Jersey Transect (for location of profiles see Site 603 and Site 604/605 chapters, this volume). A. Landward segment (U.S.G.S. line 25) crossing the continental slope and upper continental rise, with Sites 604 and 605 shown (interpretation of reflection horizons partly after Klitgord and Grow, 1980). B. Seaward segment (Conrad line 2101-77) crossing the outermost continental rise, with Site 603 shown. The disrupted, hummocky reflection configuration above Horizon Kb (see Fig. 8A) is interpreted as the response of localized sand beds and/or channel-levee mounds. 
be interpreted as designating the top and the base of the same unit.

\section{INTERPRETATION OF FACIES AND SEDIMENTATION HISTORY}

In the analysis of deep-sea cores, only a limited range of sedimentological criteria is available to infer the environment of deposition. Because the cores are narrow, virtually none of the medium- to large-scale features observable in outcrops and instrumental in facies analysis in the field are detected. Furthermore, only a limited number of widely spaced drillsites is usually available for each sedimentary basin, so that successions, even if complete, are not directly comparable and the facies are hard to correlate.

The data bases for the study of ancient turbidite systems in oceanic basins or in the subsurface are sketchy and insufficient for studies on a regional scale. A singlesite approach to the study of turbidite basins and attempts to apply existing fan models based on the interpretation of the facies both proved to be unsatisfactory (Normark et al., 1983/84; Shanmugam et al., 1985). However, using data collected from Site 603 in conjunction with seismic profiles, we can impose a few constraints on Early Cretaceous turbidite sedimentation in the area of the outer New Jersey Transect, and also discuss a possible model of sedimentation.

Interpretation of the Lower Turbidites, Interbedded with Pelagic Limestone and Marl (Turbiditic Units 1 through 6)

Distinctive features of the lower turbidites at Site 603 are (1) the occurrence of thick, clayey sandstone beds, containing rip-up shale and sandstone clasts, and (2) the abundance of interbedded pelagic sediments. Additional elements to be taken into account to constrain the sedimentation model are (3) the relevant distance from the inferred Early Cretaceous base-of-slope (Fig. 6) and (4) the hummocky, "crenulated" reflection pattern seen in the seismic profiles.

\section{Occurrence of Shale-Clast-Rich Beds}

In modern deep-sea fans, shale-clast-rich beds are preferentially found in upper- and mid-fan areas, associated with channel and channel margin deposits (Bouma, pers. comm., 1985). In ancient turbidite sequences from active margins, the same type of beds occur in one of two ways. Either they are in channeled sequences and are interpreted as the result of channel migration and local erosion (Kodiak Island, Bouma, pers. comm., 1985; Southern California, Walker, 1985; Alpes Maritimes, Bouma and Coleman, 1984), or they occur in nonchannelized sequences. In the flysch terrains of the Mediterranean Tertiary basins (Hecho Basin, Estrada, 1982; northern Spain, Van Vliet, 1978; Marnoso Arenacea and Laga Formation, Apennines, Mutti et al., 1978; Ricci Lucchi, 1978; 1983/84) and Carpathian Mountains (Marschalko, 1970), shale-clast-rich beds are typically associated with outer-fan-lobe sandstone (Mutti and Nilsen, 1981). In such settings the process of ripping up mud is thought to have taken place at local highs (e.g., the top of depositional sand bulges) and the deposition of slurried beds to have occurred in adjacent depressions (Mutti et al., 1978). Chaotic deposits containing outsized mud clasts and slumped masses are also common at the base-ofslope, resulting from slope failure and mass movements or erosion within the slope canyon (Shepard et al., 1969; Arthur and von Rad, 1979; von Rad and Arthur, 1979). In abyssal areas, the occurrence of the shale-clast-rich beds is not reported, although they are thought to be formed where an uneven seafloor (e.g., headless canyons along fracture zones) may cause local and temporary acceleration of flowing suspensions (Normark, pers. comm., 1984).

\section{Significance of Thick-Bedded Sandstone Bearing Shale Clasts at Site 603}

The occurrence of shale and sandstone clasts in most of the thick-bedded turbidites at Site 603 indicates that extensive erosion of a soft mud substratum took place during transport. The scarcity of sedimentary structures and the lack of internal organization of the beds (Fisher, 1971; Hampton, 1972; Enos, 1977) indicate that the ultimate transport mechanism was viscous flow resulting from incorporation of clay. Features diagnostic of turbulent flow conditions are unimportant or absent. Highly viscous clayey suspensions are not favorable to long-distance transport of sediments by density currents, especially in areas of flat-lying seafloor. The rapid abrasion commonly experienced by unconsolidated clasts transported within a sandy suspension suggests that in our case the distance travelled after mud intake must have been fairly short. Therefore, we conclude that most thick-bedded, shale-clast-rich clayey sandstone beds at

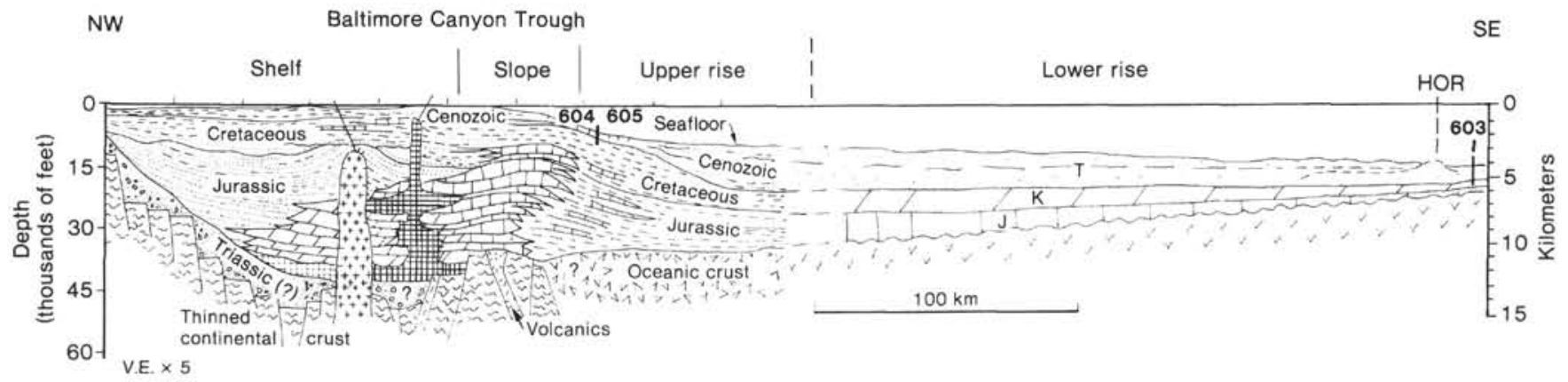

Figure 6. Schematic cross section of the New Jersey Transect (modified after Jansa and Wiedmann, 1982). HOR = Hatteras Outer Ridge. 
Site 603 may have a limited areal extent, and we envisage a local source of mud (e.g., from a channel breach or channel levee; see below) rather than a direct slope supply. Evidence for localized sand beds rather than extensive tabular sand sheets seems to be provided by the discontinuous reflection configuration of the seismic record (Fig. 5B and 8A).

\section{Pelagic Interbedding}

The occurrence of pelagic interbedding in turbiditic sequences from modern fans and ancient basins seems, to a large extent, not to be diagnostic of any specific environment (e.g., Van Vliet, 1978). The abundance of pelagic sediments seems to be chiefly related to the intensity of clastic supply, and ultimately controlled by the size and degree of confinement of the sedimentary basin into which clastics are introduced.

In the late Cretaceous and Tertiary flysch sequences of the Apennines and Pyrenees (Mutti and Ricci Lucchi, 1972; Mutti, 1978; Mutti et al., 1978; Ricci Lucchi, 1978; $1983 / 84$ ), pelagic sediments are virtually absent from large parts of mid- and outer-fan sectors. The structural confinement and the small size of the basins (compared with the volume of clastic sediment supplied) probably played a major role in overwhelming the pelagic component. In larger oceanic systems, past and present, even in active margins, pelagic sediments seem to be more common in proximal areas (California Borderland, Shepard et al., 1969; Nelson, 1983/84; Von der Borch, Sclater, et al., 1974; Van Vliet, 1978), depending upon the degree of tectonic confinement, the frequency of turbidity currents, and the dispersal pattern of clastics. Pelagic interbeds are seldom reported from sandstone lobe sequences (Van Vliet, 1978), but they are subordinate or absent where sand deposition is dominant.

Passive-margin turbidite systems are poorly studied and evidence is inconclusive. The Mississippi Fan has very little interbedded pelagic sediment, but it is confined to a enclosed basin and the sediment supply is enormous (6 to $12 \mathrm{~km} / \mathrm{Ma}$ sedimentation rates; Bouma, Coleman, et al., 1984). Packages of pelagic ooze are only deposited there at times of high-standing sea level, for example, the Holocene (Bouma, Coleman, et al., 1984), when clastic sources are extinguished. Interestingly, at these times sedimentation rates drop to values of 3 to $30 \mathrm{~m} / \mathrm{Ma}$, comparable to those of the lower turbidite succession at Site 603.

At DSDP Site 603 pelagic background sediments are conspicuous throughout the lower turbiditic succession and virtually dominant at certain intervals. Bulk sedimentation rates and frequency of turbiditic events are at least one or two orders of magnitude less than those of most modern and ancient turbidite systems (Stow et al., 1983/84; Nelson, 1983/84), suggesting highly diluted redeposition and fewer pulses in the delivery of sand.

\section{Sedimentation Model}

Low sedimentation rates (largely dominated by pelagic sediments) and low frequency of turbidites indicate that redeposition of clastic sediments was subdued at Site 603 during Hauterivian-Barremian time. We speculate that clastic sediment starvation might be the result of an actual low sediment supply or it might be an indication that most turbidity currents were confined into levees of major channels while passing by Site 603 . We do not believe that distance from clastic source (i.e., the slope canyon) was a controlling factor because, in that case, sedimentological and seismic evidence of distal, basin-plain deposits should be expected. The presence of disorganized, shale-clast-rich clayey sandstone beds associated with thin-bedded classical turbidites instead suggest that deposition might have occurred sporadically in a sediment-starved interchannel plain, under the influence of channel activity. The abundance of rip-up clasts is taken as an indication of the vicinity of a mudstone source. The uniform lithology of the rip-up clasts, that is, dominantly black turbiditic claystones, may indicate a levee origin.

Slumping of sediments is a common feature in turbiditic Unit 5, implying the existence of local topography. Channel margins and levees can have slopes as steep as several degrees (Stow, 1981), sufficient to support extensive mass movements. Sediments were not slumped in flat-lying interchannel settings. Turbiditic Units 4 and 5 (Fig. 1), which are sand-rich and are virtually devoid of pelagic sediments, were interpreted as being deposited in the vicinity of, if not within, an active channel and related levee slopes. The limited width of the cores does not provide any clue from which to infer the channeled or unchanneled geometry of these sands. The diluted thinning-upward and thickening-upward sequences of Units 2 and 5-6, and Unit 3, respectively (Fig. 3), might be related to lateral channel migration, with a thinningupward sequence indicating channel migration away from the depositional site and vice versa. Channel migration and breakthrough of the levees is the mechanism envisioned to produce the rip-up mudstone clasts at Site 603 . A similar mechanism is inferred by Bouma and Coleman (1984) and Walker (1985).

The "hummocky" reflection pattern in seismic Unit 7 (Figs. 5B and 8A) might indicate channel-levee structures and/or the presence of beds of limited lateral extent. Such a reflection style is rather indicative of channel-leveed units, either in modern fans (Kolla and Buffler, 1983/84; cf. their fig. 6), or in ancient subsurface systems (Mitchum, 1984). The scale of reflection mounds (Fig. 5B and 8A) is comparable with that of channels and channel-related features of modern and ancient turbidite systems (Barnes and Normark, 1983/84). A "crenulated" reflection configuration persists landward, in seismic Unit 7, which is enveloped between $\mathrm{Kb}$ and $\beta$ reflectors (Fig. 5A), up to the base-of-slope. Such evidence could indicate the landward extension of the same channel-leveed unit to the base-of-slope, although more seismic profiles must be studied.

We speculate that turbidity currents reached Site 603 endowed with sufficient kinetic energy to produce channel migration and levee erosion. Such processes are active at meander bends, where flows are forced to deviate and are usually "stripped" of a substantial part of their load (Normark et al., 1979; Piper and Normark, 1983). Flow stripping at levee breaches might control the formation of new channel branches and might predetermine new sites of sand deposition (Fig. 7). We suggest that the 


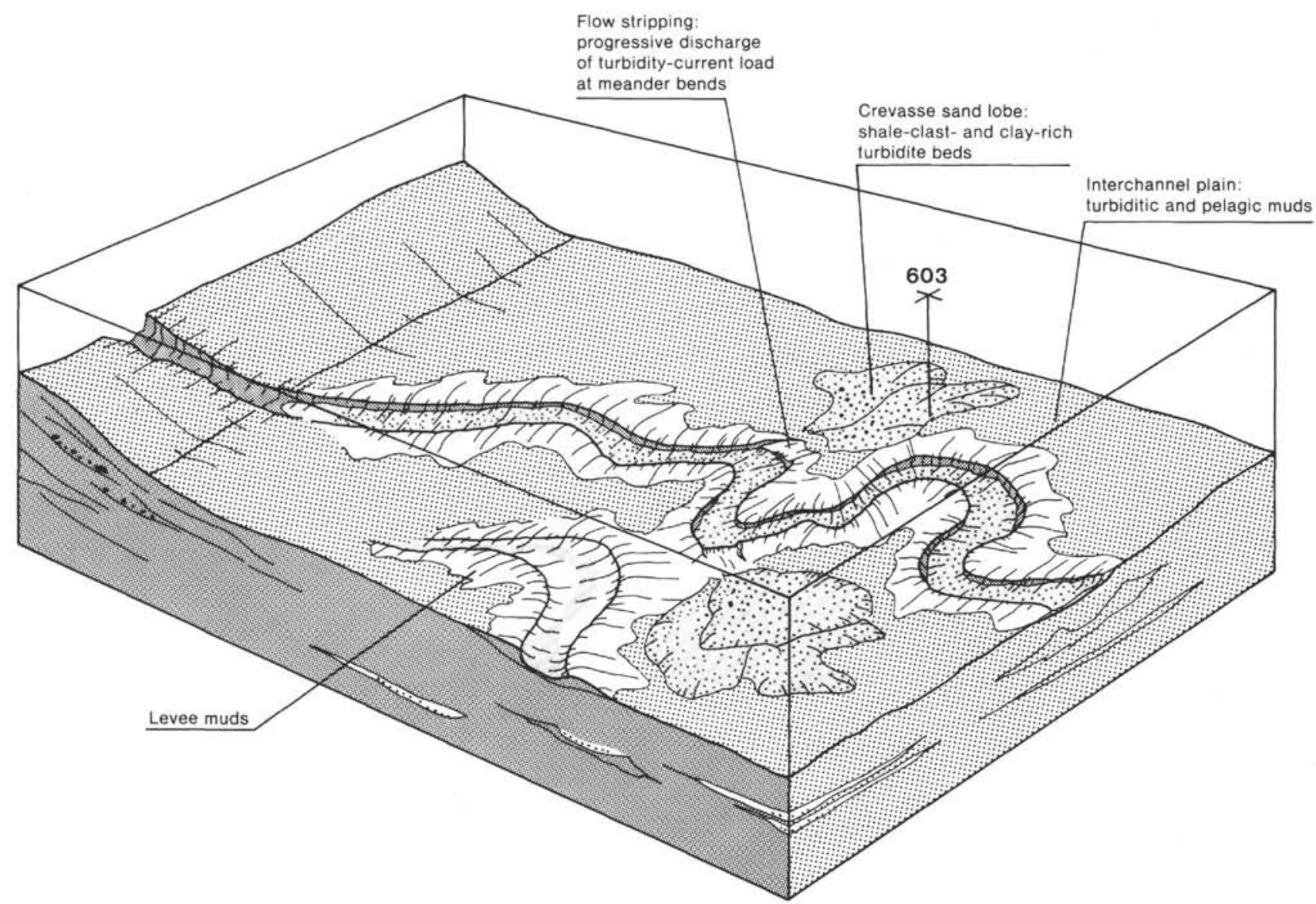

Figure 7. Block diagram showing an idealized, mid-fan setting, possible site of deposition of the lower turbiditic sequence at Site 603. Channel-related, flow-stripping sands are shown at meander bends.

massive sandstones of Unit 4, which closely resemble lobe sequences exposed on land, may be interpreted as a sand lobe produced by a "crevasse" (Fig. 8A). Thin-bedded classical turbidites composed of fine sand and silt, so common at Site 603 , have been interpreted as overbank deposits in channel margin and interchannel sequences (Mutti, 1978; Walker, 1985).

According to the model proposed, turbidity currents are envisioned as having bypassed the Site 603 area and discharged their sediment load seaward. Seismic evidence of a sand depocenter (convex-upward units with divergent downlapping internal reflectors: Mitchum, 1984), corresponding to the outer-fan sandstone lobes of ancient turbidite systems or the "suprafan" of modern fans (Normark, 1970), is actually lacking. Ancient turbidite systems at times of high-standing sea level and most modern, passive-margin fans (e.g., Mississippi Fan), do not display outer-fan sand lobes, depending upon the type of sediment supplied. Mud-laden turbidity currents favor the development of extensive, lobefree channel-levee systems (Mutti, 1984; Bouma, Coleman, et al., 1984).

\section{Interpretation of the Unconsolidated Sand of Turbiditic Unit 7}

Because of the poor recovery and intense drilling disturbance, sedimentological criteria offer no clues to the environment of deposition of the unconsolidated sands of Unit 7. Seismically, turbiditic Unit 7 is thought to correspond to the few parallel reflection horizons which overlie Horizon $\beta$ in Figure 5B. The same parallel reflectors are traceable landward and are seen to overlie the "crenulated" reflecting unit in Figure 5A. Therefore, we are tempted to conclude that the turbiditic Unit 7 represents a massive sand sheet extending landward to the base-of-slope. Seismic reflection horizons are seen to onlap onto the base-of-slope (Fig. 5A), giving credibility to this inference. The volume of the sand, according to the most conservative estimates, would be approximately 900 to $950 \mathrm{~km}^{3}$. The time lapse involved in its emplacement is not known, because an erosional unconformity of unknown duration is postulated to exist at the base of the unit. Assuming minimum sedimentation rates of $100 \mathrm{~m} /$ m.y., effective in modern and ancient outer fans (Stow et al., 1983/84), deposition of the unconsolidated sand Unit 7 should have had a duration of less than $1 \mathrm{~m} . \mathrm{y}$.

Sedimentation History and Sea Level Changes (Fig. 8).

Early Cretaceous turbidite sedimentation off the Baltimore Canyon Trough has been controlled chiefly by basin morphology, rates and type of sediment supply, and changes in sea level. Enhanced sediment supply from continents seems to have begun turbiditic deposition in 
Valanginian time. Lowering of the sea level is thought to have controlled the release of substantial sand in Aptian time.

In Valanginian to Barremian times, restricted areas of the lower continental rise off North America were sites of redeposition for shelfal sands and muds (Sheridan, Gradstein, et al., 1983; Benson, Sheridan, et al., 1978; this chapter). In the Site 603 area, turbidites fill a trough (Fig. 5B), but they are lacking over nearby morphologic highs, where carbonate-rich, biogenic sediments dominate (e.g., at DSDP Site 105; Hollister, Ewing, et al., 1972). We interpret the turbidites at Site 603 as having been deposited in an elongate channel-levee-type fan system, structurally confined in its distal portion (Fig. 5B). Low sedimentation rates and frequency of turbidites suggest that the input of clastic sediments was rather low, although the confinement of turbidity currents within levees of major channels is expected to have contributed to sediment starvation in the adjacent interchannel plains. The lack of outer-fan sands, if confirmed, might signify that not enough sediment was available to build up lobes at those times. In the western North Altantic, no major resedimentation is known to have occurred in Valanginian to Barremian times, although enhanced sediment supply from the continent is recorded from various areas of the North Atlantic Basin (see later). Some sequences in the western North Atlantic contain substantial turbidites (e.g., Sites 603, 534, Robertson and Bliefnick, 1983; Site 391), but most of the other DSDP sites do not record any significant redeposition. The absence of Lower Cretaceous deep-sea sands from vast areas of the North American continental margin has been related chiefly to the barrier effect of Early Cretaceous carbonate platforms. Carbonate banks are thought to have been developed as a continuous belt along the edge of the North American continental shelf (Schlee et al., 1976; Folger et al., 1979; Tucholke and Mountain, 1979. The development of extensive carbonate platforms has been questioned (Jansa, 1981), and their age is still poorly constrained (?Late Jurassic, ?Early Cretaceous). After turbidites were discovered at a few DSDP sites, the possibility of breaches in the platform barrier was postulated, in order to account for local turbidite deposition (Jansa, 1981; Wise et al., this volume). Schlee (1981) has described Early Cretaceous clastics overflowing a shelf-edge barrier, thus restricting the age of the postulated carbonates to the middle and late Jurassic. In our opinion, reefs might not have acted as extensive barriers against clastic sediments, because reefs hardly develop in regions of intense terrigenous sediment supply. Alternatively, we suggest that redeposition was generally subdued because clastic sediments were largely deposited on the shelf, under the influence of a rising or high-standing sea level. Sea-level rise is expected to accommodate sediments in the shallow-water domain, so little is available to be displaced beyond the shelf edge.

Shelf upbuilding and outbuilding is a regional event that occurred in different basins around the North and central Atlantic during a Hauterivian to Barremian sealevel rise (e.g., the Baltimore Canyon Trough, Schlee, 1981; the Wealden terrains of northwest Europe, Allen, 1975; the deltaic systems of the Northwest African con- tinental margin, off Morocco, Lancelot and Winterer, 1980; von Rad and Einsele, 1980; Wissmann, and von Rad, 1979; Wiedmann et al., 1978; see later); the Scotian shelf Jansa and Wade, 1975). Associated high-stand turbidite systems show evidence of sediment starvation and a suite of features which seem to be related to channel-interchannel deposition (e.g., Site 603). Shelf construction and development, at the same time, of sediment-starved channel-levee complexes is documented from Tertiary basins of northern Spain, and related to periods of high sea-level stands (Mutti, 1984). This model seems to be applicable to the ancient turbidite systems in offshore basins (Mitchum, 1984) and to the Early Cretaceous turbidites off the Baltimore Canyon Trough.

The upper unconsolidated sands were emplaced before mid-Aptian time, over a period which might have lasted less than $1 \mathrm{~m} . \mathrm{y}$. We speculate that they correspond to an extensive sand sheet extending to and onlapping onto the base-of-slope. Because of the considerable volume of sediment involved, we interpret the unconsolidated sands of turbiditic Unit 7 (Fig. 3) as the product of a phase of intense shelf erosion (Fig. 8B), rather than enhanced river supply of lateral migration of a sandprone fan subenvironment. Interestingly, no material derived from carbonate platforms is associated with the terrigenous sands, suggesting either that carbonate buildups were absent or not exposed in the source area or that carbonate debris was deposited landward. Shelf dismantling and major release of clastic sediments into basins occur when the sea level is lowered (Vail et al., 1977; Shanmugam and Moiola, 1982; Mitchum, 1984; Bouma, Coleman, et al. 1984). A number of independent lines of evidence (Vail et al., 1977) suggest an Aptian drop in sea level; the unconsolidated sands of mid-Aptian age at Site 603 are taken as its expression. In the Tertiary basins of northern Spain, extensive channel-detached sand lobes were formed at times of lowered sea level and are physically correlated with unconformities on the shelf (Mutti, 1984). This proves that major resedimentation coincided with phases of shelf destruction and vice versa.

The redeposition of coarse-grained, clastic sediments at the Aptian/Albian boundary ceased suddenly. Its end coincided, in the basin, with the change from carbonate-rich to carbonate-free pelagic deposition and with the extensive development of organic-matter-rich "black shales." Changes in sea level are thought to result in consistent changes in the depth of carbonate dissolution levels, affecting pelagic deposition in the deep ocean. Transgressions over shelves and enhanced productivity probably favored the development of anoxic waters and the preservation of organic matter (Schlanger and Jenkyns, 1976). Flooding of shelves is also expected to have virtually extinguished terrigenous supply to the deep ocean and favored the dominance of pelagic sedimentation. A rise in sea level at the Aptian/Albian boundary (Vail et al., 1977) might explain the coincidence of the three events (Haggerty et al., this volume).

\section{Comparison with Other Deep-Sea Fan Deposits Around the Early Cretaceous Atlantic Ocean}

During the Late Jurassic, the narrow North AtlanticTethys Seaway was bordered by large carbonate platforms, 


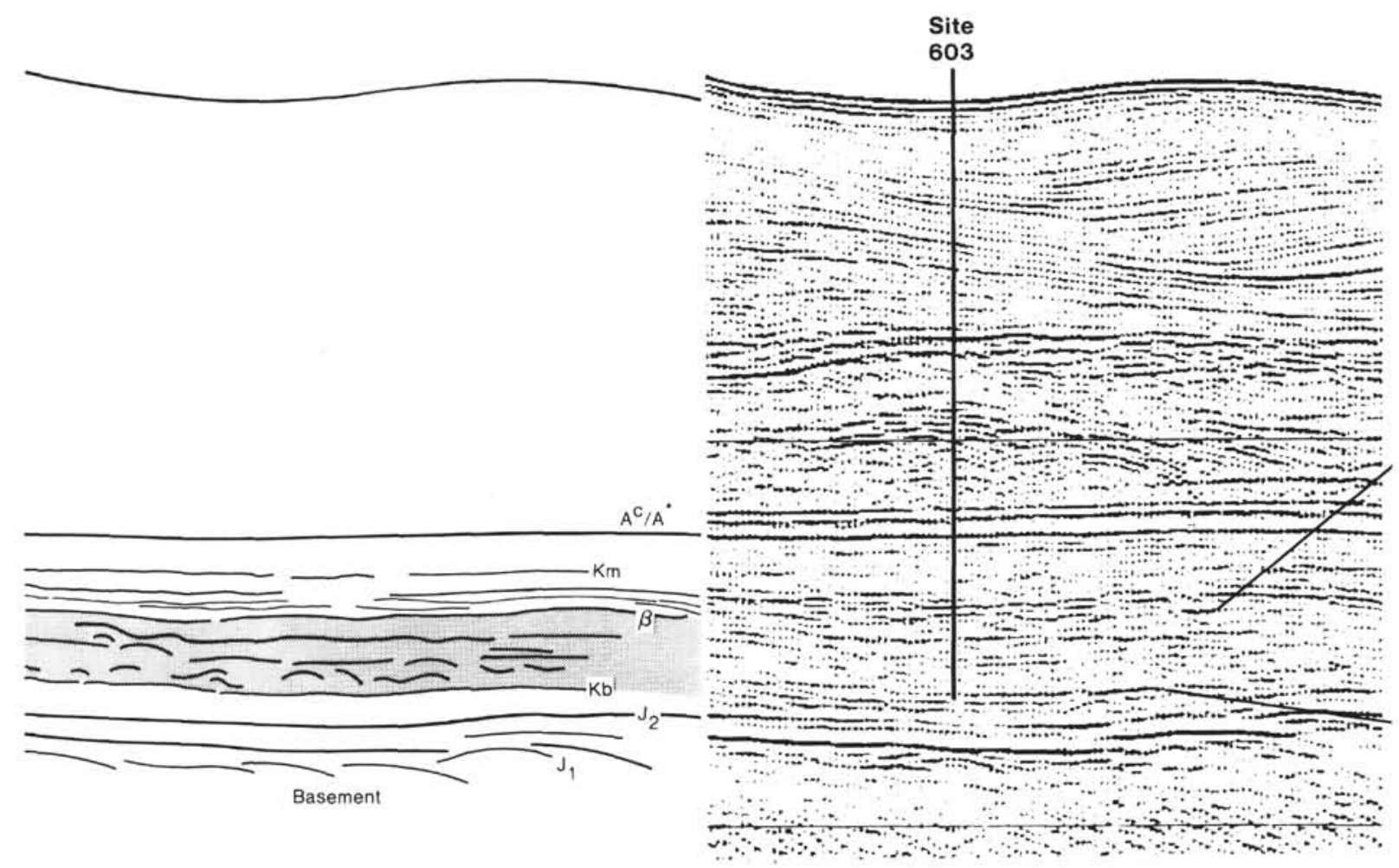

Figure 8. Facies model and sedimentary history for the Early Cretaceous turbidites of Site 603. A. Generalized cross-section of the vicinity of Site 603. Leveed channels (mound symbols) and related "crevasse"/overbank turbidites are shown to be deposited within a large-scale structural trough, seen in the seismic profiles. B. Four palinspastic profiles showing the postulated evolution of the outermost continental rise near Site 603, between Berriasian and Albian times (modified after Mutti, 1984). Section 1 shows a preHauterivian situation. The lower turbidites were deposited when the sea level was rising or high-standing (Hauterivian-Barremian) (Section 2). The massive, unconsolidated top sands follow a mid-Aptian lowering of the sea level (Section 3). In late Aptian/Albian time, turbidite sedimentation ceased, possibly after a rise in the sea level (Section 4). For explanations, see text.

especially along the continental margins of the Tethys, Northwest Africa, and eastern North America, south of a paleolatitude of about $25^{\circ} \mathrm{N}$. During Berriasian to Valanginian times an important change toward a more terrigenous clastic sedimentation occurred (Figs. 1, 9). The Valanginian proto-Atlantic-Tethys Seaway was an eastwest-trending ocean basin, $1000-1500 \mathrm{~km}$ wide and nowhere deeper than $4000 \mathrm{~m}$. Along the southern and northern margins of this "seaway," large "Wealden-type: deltaic systems were built out, shedding huge amounts of terrigenous clastic sediments on alluvial plains, into freshwater lakes, brackish inland seas, and on the adjacent shelves (von Rad and Arthur, 1979). The "Wealden" (s.str.) is a facies designation for a $200-500$-m-thick sequence of fluviatile, lacustrine, or brackish lignite-rich sandstones, siltstones, and shales which were deposited during the latest Jurassic to Barremian early-rift stages of the northeastern Atlantic (Allen, 1959, 1975; Anderton et al., 1979). Well-known Wealden deposits occur in southeastern England, the Paris Basin, Lower Saxony and central Germany, Poland, and Denmark, as well as in the Parentis and Adour basins in southwest France and the
Cantabrian Trough and Iberic Ranges in northern Spain (Fig. 1).

More or less during the same time, we observe turbidites in the basins along the Northwest African and Iberian continental margins, between Cape Bojador and northwestern Spain, and along the eastern North American margin between Cape Hatteras and Newfoundland (see Fig. 1; von Rad and Arthur, 1979; Jansa et al., 1979; Jansa and Wiedmann, 1982; Emery and Uchupi, 1984; von Rad and Sarti, 1986).

In the Aaiun Basin, a very thick (1-3 km) pile of deltaic sediments prograded over the Tithonian to Berriasian carbonate platform and produced a seaward-thickening clastic wedge with an upward and seaward facies transition from continental clastics to a major delta system (von Rad and Arthur, 1979; von Rad and Wissmann, 1982). This widespread Hauterivian to Barremian Wealden-type delta system can be traced from the onshore Aaiun Basin and shelf wells (alluvial to shallow nonmarine facies; Ranke et al., 1982) to distal prodelta mudstones on the upper rise (Site 397; Einsele and von Rad, 1979; von Rad and Einsele, 1980). The seaward continu- 


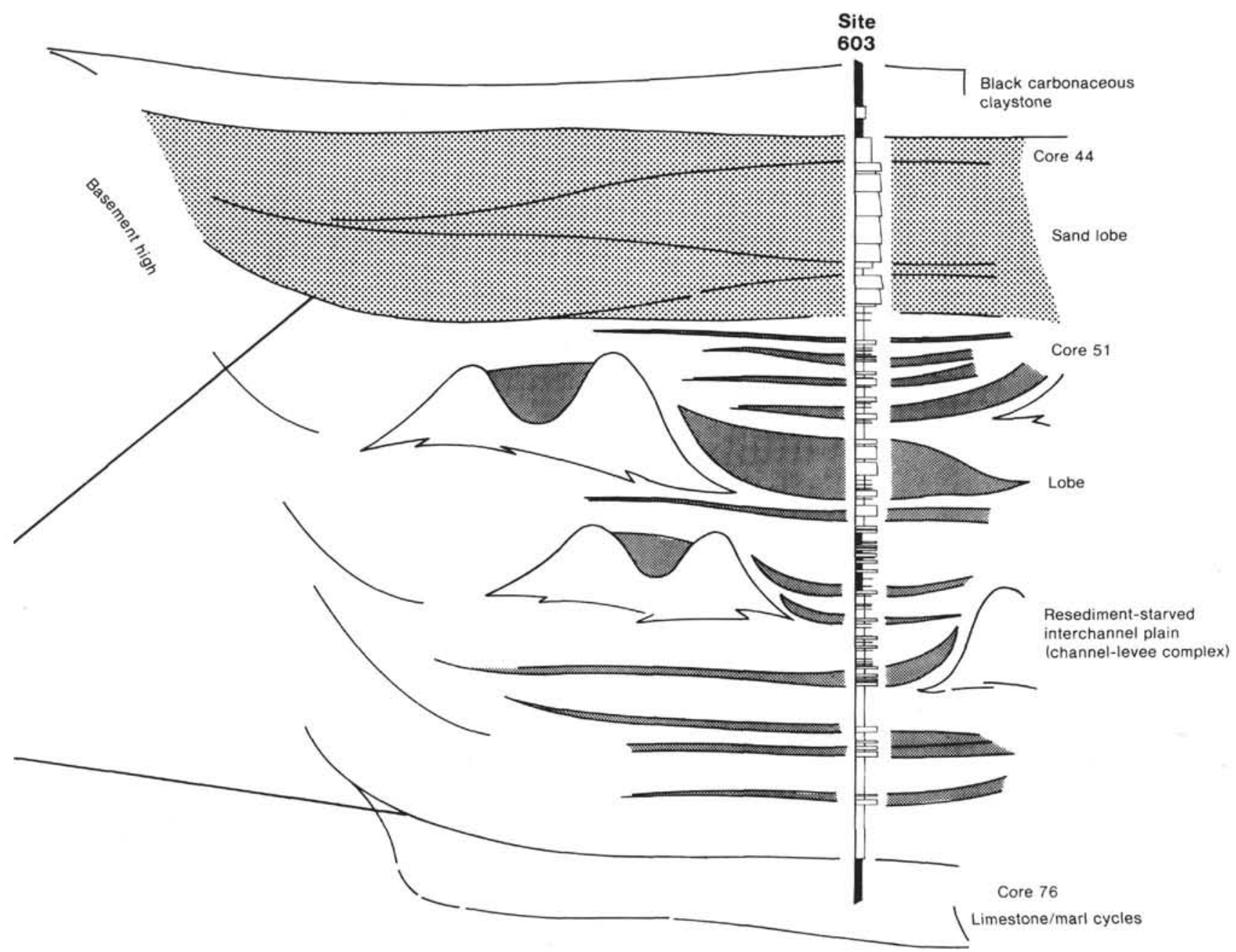

Figure 8 (continued).

ation of this facies can be studied in the 1500-m-thick Valanginian to Hauterivian section of the uplifted and deeply eroded turbidite sequence on the island of Fuerteventura (Robertson and Bernoulli, 1982), which was deposited in a distal deep-sea fan environment. At the nearby offshore section of the northern Tarfaya Basin, the Upper Jurassic carbonate platform is buried by a seaward-thickening wedge of deltaic to prodeltaic Wealden-type clastics, the Tan-Tan Formation, which is 1 to $>3 \mathrm{~km}$ thick (Mitchum and Vail, 1977; von Rad et al., 1985).

The Upper Jurassic to Berriasian carbonate platform of the Mazagan Plateau, Escarpment, and Slope at the sediment-starved central Moroccan continental margin has been thoroughly studied by seismic surveys (Hinz et al., 1982), deep-sea drilling (Winterer and Hinz, 1984) and the CYAMAZ diving campaign (von Rad et al., 1985). Figure 9 summarizes the facies evolution in the Mazagan area between mid-Jurassic and Cenomanian time, and correlates it with global sea level, a regional regression-transgression curve, and major blockfaulting events. A "Wealden-type" bioclastic turbidite facies is restricted to a paleocanyon-fan system, discovered to the south of the Mazagan Plateau, which might have been active during a regional Hauterivian regression (von Rad et al.,
1985). At Site 416, to the southwest of the Mazagan Plateau, $750 \mathrm{~m}$ of distal turbidites and pelagites were deposited on a distal deep-sea fan. The change from calcareous to siliciclastic composition recorded the drowning of the carbonate platform and enhanced sediment supply in the latest Jurassic-Hauterivian (Schlager, 1980; Lancelot and Winterer, 1980). The thick, hemipelagic, late Aptian to Albian nannofossil marls at the lower Mazagan Slope were deposited during the late Aptian-Albian sea-level rise (Vail et al., 1977), in a similar fashion to the coeval black shales at Site 603 .

\section{Discussion}

During Valanginian to Barremian time, outbuilding of shelves and emplacement of turbidites in basins around the North Atlantic Ocean were influenced by a variety of factors (tectonics, climate, physiography of the basin and geography of the hinterland, sea-level fluctuations) whose relative importance is different for each individual case. The exact timing of delta formation and deepsea fan progradation varied from place to place, being largely controlled by the interference of local factors. The effects of the changes in sea level are difficult to establish at times of high sediment supply, and difficulties arise from the lack of detailed stratigraphic information 
M. SARI, U. NON RAD

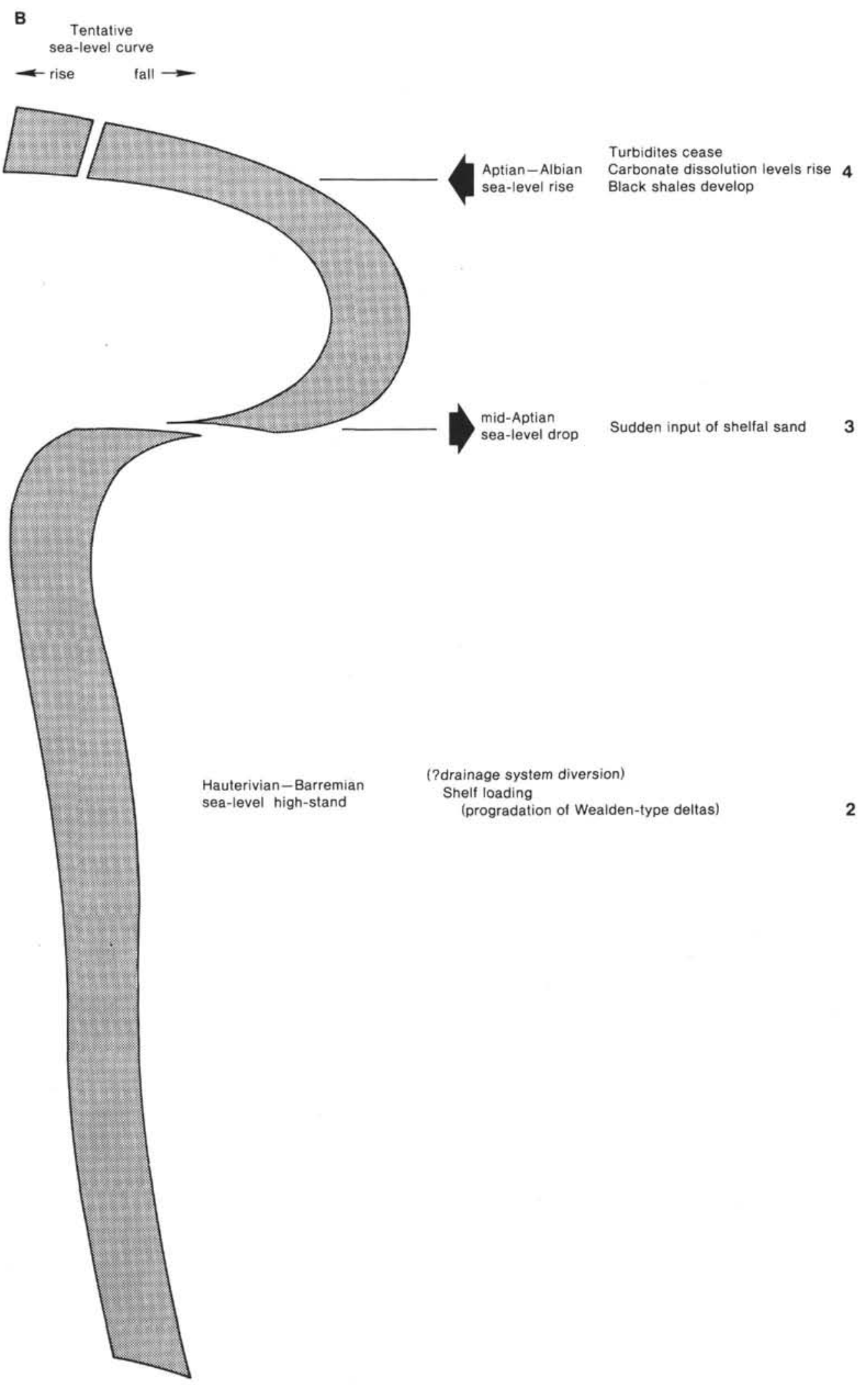

Figure 8 (continued).

916 

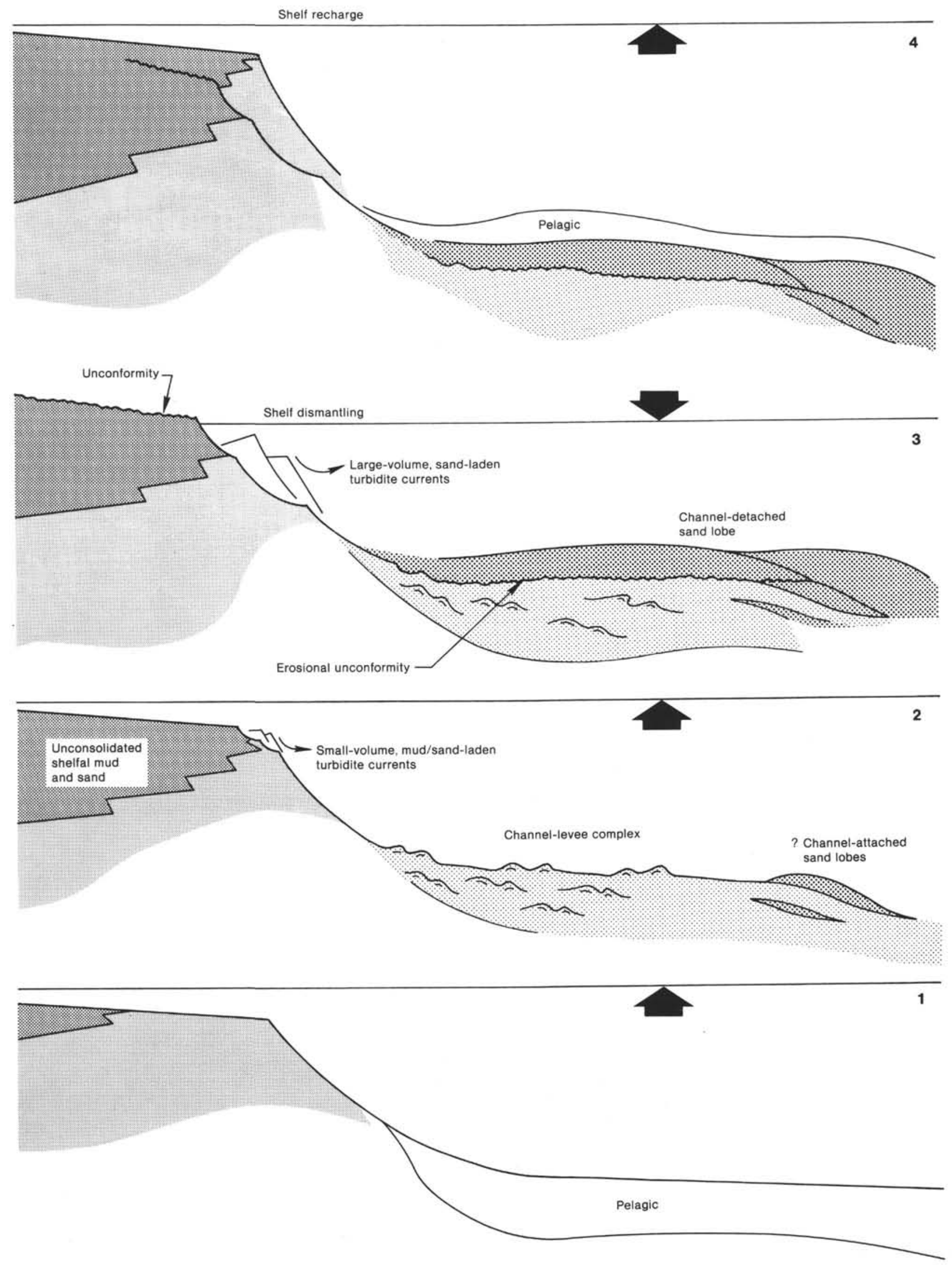

Figure 8 (continued). 


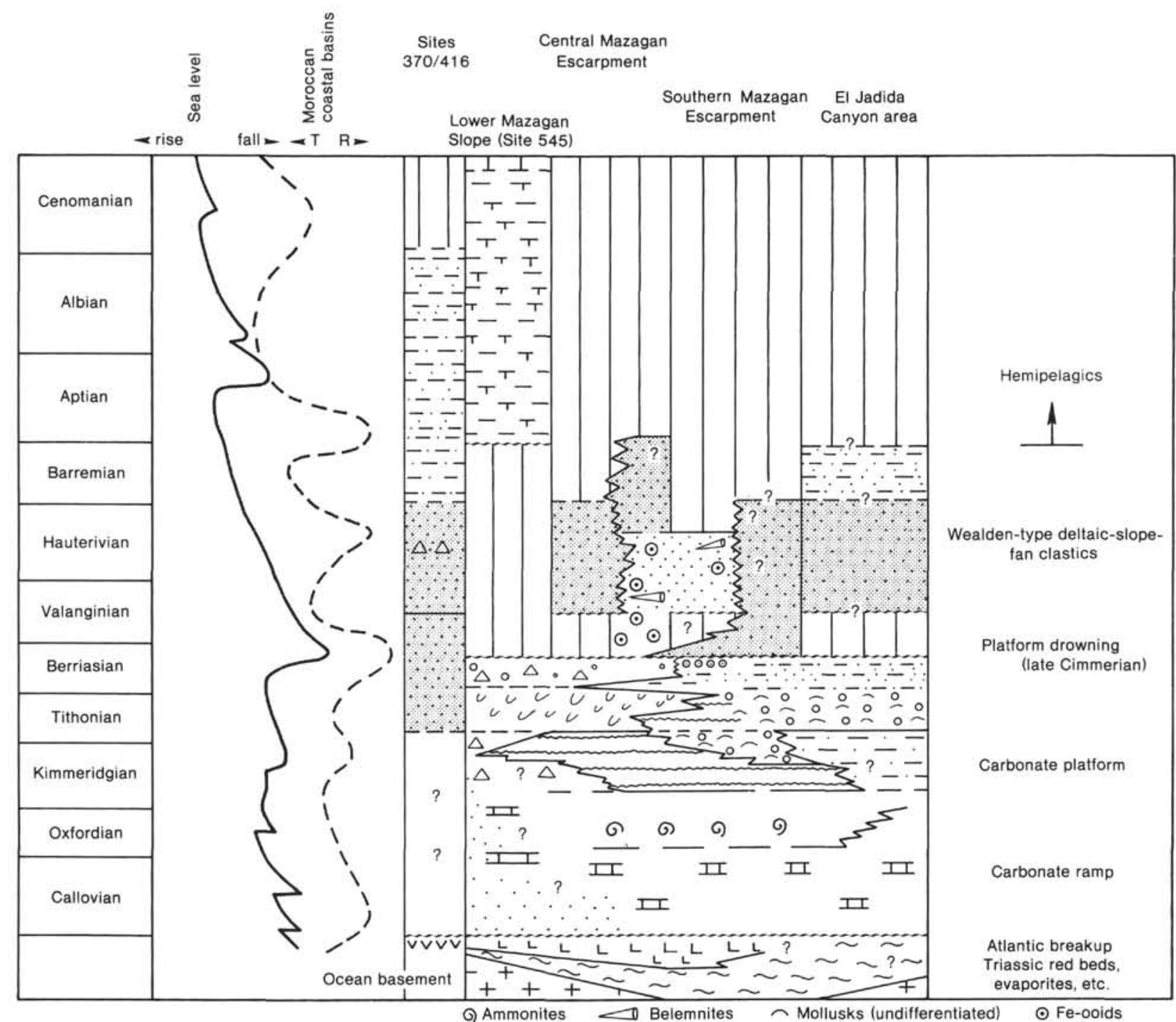

Figure 9. Time-stratigraphic summary of the results of the CYAMAZ campaign, DSDP Legs 50 and 79 in the area of the Mazagan Plateau and Escarpment and the Moroccan Basin (modified after von Rad et al., 1985). Sea-level fluctuations after Vail et al. (1977) and Vail et al. (1984). Transgression/regression curve (T-R) of Moroccan coastal basins refers to relative sea-level changes, also influenced by tectonics, subsidence, accumulation, and erosion rates. Note the presence of Wealden-type deltaic complexes of Valanginian to Barremian age (southern Mazagan Escarpment, El Jadida Canyon, southeastern Mazagan Plateau horst) and coeval turbidites (DSDP Sites 370/ 416 and lower Mazagan slope [shading]). For discussion, see text.

in these largely unfossiliferous or fossil-poor sequences, However, the loading of the shelves by Wealden-type deltas seems to have occurred chiefly during a Valanginian to Barremian sea-level rise or high-stand, while sandand mud-laden turbidity currents spilled down beyond the shelf edge and fed turbiditic systems. Hence, it seems to be necessary to re-evaluate the Northwest African and similar turbidite systems. The facies, age, and accumulation rates of those turbiditic sequences must be checked in detail, like Site 603. The occurrence of sandy formations of Aptian age, coeval with unconsolidated sands of Site 603 , has to be evaluated in order to prove whether or not the model is generally applicable.

\section{SUMMARY AND CONCLUSIONS}

Conflicting evidence renders it difficult to apply any of the proposed models of turbidite fan deposition (see
Howell and Normark, 1982) to the succession at Site 603. Sedimentological and seismic data favor the hypothesis of an elongated, structurally confined channel-leveeinterchannel complex, developing from Valanginian to Barremian times and extending seaward from the baseof-slope to the lower continental rise (Figs. 5, 8A). Such a hypothesis does not conflict with recent findings about modern passive and active margin fans which document the existence of extensive channel-levee-interchannel complexes extending many hundreds of kilometers seaward of the feeding slope (Bouma and Coleman, 1984; Nelson, 1983/84; Kolla and Buffler, 1983/84; Damuth and Flood, 1983/84; Emmel and Curray, 1983/84. Channeled areas form approximately 40 to $80 \%$ of the surface of most modern fans (Barnes and Normark, 1983/84). Turbidite systems with a low sand:shale ratio, typical for most passive-margin fans, favor the development of sand- 
efficient feeder systems with extensive channel networks (Bouma, pers, comm., 1985; Bouma and Coleman, 1984; Mutti, 1979; 1984). In such systems outer-fan sand bodies are poorly developed or absent.

Recent research on fan sedimentation has focused on channel formation and migration and on the mechanism of meandering. Although the evidence is still inconclusive, a mechanism which involves lateral migration and vertical aggradation has been proposed (Bouma, Coleman, et al., 1984; Walker, 1985). Thinning-upward and thickening-upward sequences, as well as sand-rich units, are interpreted to be a result of changes in channel activity (activation, switching and migration, breakthrough of levees) rather than of actual changes in the volume of sediment delivered.

The turbidites of Site 603, which formed at times of high-standing or rising sea level, are small-volume, lensoid sand bodies enclosed within clayey facies. Their high clay content leads to a low primary porosity, unfavorable to the accumulation of significant oil and gas. The "sea-level low-stand" topmost sands, instead, fulfill the requirements for good hydrocarbon reservoirs in their porosity and volume. Not all sand-rich turbidite sequences have to be regarded as possible oil-bearing formations, but different turbidite facies may have different hydrocarbon potential. Many hydrocarbon productions are from sand-prone outer (lower) fan sands (Mitchum, 1984), rarely from upper-fan (channel-fill) sands (Webb, 1981). Seismic data may help in recognizing structural and morphologic settings where turbidites are deposited and are instrumental in the interpretation of facies. The analysis of seismic profiles and facies may help to predict where large masses of sand (lobe belt) were deposited. Seismic stratigraphic studies in the area of the lower continental rise off North America have suggested that extensive sandlobe belts might not be developed when the sea level is high and that substantial sands were released only during lowering of the sea level. In our opinion, changes in sea level and structural-physiographic setting were more important elements in controlling turbiditic deposition off the New Jersey slope than local factors (climate, sediment supply, etc.) or fan subenvironments.

\section{ACKNOWLEDGMENTS}

The authors thank the Deep Sea Drilling Project for inviting them to participate on Leg 93 aboard the Glomar Challenger. We are very grateful to our co-chief scientists, J. E. van Hinte and S. W., Wise, to our co-shipboard sedimentologists, J. A. Haggerty and J. G. Ogg, for many fruitful discussions on the description and interpretation of the sediments of the Blake-Bahama Formation, and to our fellow shipboard scientists, technicians, and the ship's crew of the Glomar Challenger. We also express our gratitude to A. Bosellini, L. Jansa, H. C. Jenkyns, G. S. Mountain, E. Mutti, W. R. Normark, J. G. Ogg, and E. L. Winterer for discussions and comments on the earlier manuscript. We gratefully acknowledge the thorough reviews by A. H. Bouma, D. A. Dunn, and M. T. Ledbetter. M. Sarti thanks the Consiglio Nazionale delle Ricerche, Rome, for financial support (Grant No. 85.00995.05).

\section{REFERENCES}

Allen, P., 1959. The Wealden environment, Anglo-Paris Basin. Phil. Trans. R. Soc. London. Ser. B, 242:283-346.

1975. Wealden of the Weald: a new model. Proc. Geol. Assoc., 86:389-438.

Anderton, R., Bridges, P. H., Leeder, M. R., and Sellwood, B. W., 1979. A Dynamic Stratigraphy of the British Isles: A Study in Crustal Evolution: London (George Allen \& Unwin), pp. 227-244.
Arthur, M. A., and von Rad, U., 1979. Early Neogene base-of-slope sedimentation at Site 397, DSDP Leg 47A: Sequential evolution of gravitative mass transport processes and redeposition along the Northwest African passive margin. In von Rad, U., Ryan, W. B. F., et al., Init. Repts. DSDP, 47, Pt. 1: Washington (U.S. Govt. Printing Office), 603-639.

Barnes, N. E., and Normark, W. R., 1983/1984. Diagnostic parameters for comparing modern submarine fans and ancient turbidite systems. Geomar. Lett., 3 [Map].

Benson, W. E., Sheridan, R. E., et al., 1978. Site 391: Blake-Bahama Basin. In Benson, W. E., Sheridan, R. E., et al., Init. Repts. DSDP, 44: Washington (U.S. Govt. Printing Office), 153-336.

Bouma, A. H., and Coleman, J. M., 1984. Grés de Peira-Cava, French Alpes Maritimes. Characteristics of Gulf Basins Deep-Water Sediments and Their Exploration Potential. Fifth Ann. Res. Conf. Gulf Coast Sect., Soc. Econ. Paleontol. Mineral. Found., pp. 23-24.

Bouma, A. H., Coleman, J. M., and Leg 96 Scientific Crew, 1984. Seismic stratigraphy and sedimentology of Leg 96 drilling on the Mississippi Fan. Characteristics of Gulf Basins Deep-Water Sediments and Their Exploration Potential. Fifth Ann. Res. Conf. Gulf Coast Sect., Soc. Econ. Paleontol. Mineral. Found., pp. 11-22.

Damuth, J. E., and Flood, R. D., 1983/1984. Morphology, sedimentation processes and growth pattern of the Amazon deep-sea fan. Geomar, Lett., 3:109-118.

Einsele, G., and von Rad, U., 1979. Facies and paleoenvironment of Lower Cretaceous sediments at DSDP Site 397 and in the Aaiun Basin (Northwest Africa). In von Rad, U., Ryan, W. B. F., et al., Init. Repts. DSDP, 47, Pt. 1: Washington (U.S. Govt. Printing Office), 559-577.

Emery, K. O., and Uchupi, E., 1984. The Geology of the Atlantic Ocean: New York (Springer).

Emmel, F. J. and Curray, J. R., 1983/1984. The Bengal submarine fan, northeastern Indian Ocean. Geomar. Lett., 3:119-124.

Enos, P., 1977. Flow regimes in debris flow. Sedimentology, 24:133142.

Estrada, M. R., 1982. Lobulos desposicionales de la parte superior del Grupo de Hecho entre el anticlinal de Boltaña y el Rio Aragon (Huesca) [Ph.D dissert.]. Universidad Autonoma de Barcelona, Spain.

Fisher, R. V., 1971. Features of coarse-grained, high-concentration fluids and their deposits. J. Sed. Petrol., 41:916-927.

Folger, D. W., Dillon, W. P., Grow, J. A., Klitgord, K. D., and Schlee, J. S., 1979. Evolution of the Atlantic continental margin of the United States. In Talwani, M., Hay, W., and Ryan, W. B. F., (Eds.), Deep Drilling Results in the Atlantic Ocean: Continental Margins and Paleoenvironment. Am. Geophys. Un., Maurice Ewing Ser., 3:87-108

Hampton, M. A., 1972. The role of subaqueous debris flow in generating turbidity currents. J. Sed. Petrol., 42:775-793.

Harland, W. B., Cox, A., Llewellyn, P. G., Pickton, C. A. G., Smith, A. G., and Walters, R., 1982. Geologic Time Scale: Cambridge (Cambridge University Press).

Hinz, K., Dostmann, H., and Fritsch, J., 1982. The continental margin of Morocco: seismic sequences, structural elements and geological development. In von Rad, U., Hinz, K., Sarnthein, M., and Seibold, E. (Eds.), Geology of the Northwest African Continental Margin: New York (Springer), pp. 34-60.

Hollister, C. D., Ewing, J. I., et al., 1972. Site 105: Lower continental rise hills. In Hollister, C. D., Ewing, J. I., et al., Init. Repts. DSDP, 11: Washington (U.S. Govt. Printing Office), 219-312.

Howell, D. G., and Normark, W. R., 1982. Sedimentology of submarine fans. In Scholle, P. A., and Spearing, D. (Eds.), Sandstone Depositional Environments. Am. Assoc. Pet. Geol. Mem., 31:365404.

Jansa, L. F., 1981. Mesozoic carbonate platforms and banks of the eastern North American margin. Mar. Geol., 44:97-117.

Jansa, L. F., Enos, P., Tucholke, B. E., Gradstein, F. M., and Sheridan, R. E., 1979. Mesozoic-Cenozoic sedimentary formations of the North American Basin, western North Atlantic. In Talwani, M., Hay, W., and Ryan, W. B. F. (Eds.), Deep Drilling Results in the Atlantic Ocean: Continental Margins and Paleoenvironment. Am. Geophys. Un., Maurice Ewing Ser., 3:1-57.

Jansa, L. F., and McQueen, R. W., 1978. Stratigraphy and hydrocarbon potential of the central North Atlantic Basin. Geosci. Cana$d a, 5(4): 176-183$. 
Jansa, L. F., and Wade, J. A., 1975. Geology of the continental margin off Nova Scotia and Newfoundland. In van der Linden, W. J. M., and Wade, J. A. (Eds.), Offshore Geology of Eastern Canada. Can. Geol. Surv. Pap., 74-30:51-106.

Jansa, L. F., and Wiedmann J., 1982. Comparison of the Northwest African and northeast American margins. In von Rad, U., Hinz, K., Sarnthein, M., and Seibold, E. (Eds.), Geology of the Northwest African Continental Margin: New York (Springer), pp. 215269.

Kelts, K., and Arthur, M. A., 1981. Turbidites after ten years of deepsea drilling - wringing out the mop? In Warme, J. E., Douglas, R. C., and Winterer, E. L. (Eds.), The Deep Sea Drilling Project: $A$ Decade of Progress. Soc. Econ. Paleontol. Mineral. Spec. Publ., 32:91-127.

Klitgord, K. D., and Grow, J. A., 1980. Jurassic seismic stratigraphy and basement structure of the Western Atlantic Magnetic Quiet Zone. Am. Assoc. Pet. Geol. Bull., 64:1658-1680.

Kolla, V., and Buffler, R. T., 1983/1984. Morphologic, acoustic and sedimentologic characteristics of the Magdalena Fan. Geomar. Lett., 3:85-91.

Lancelot, Y., Hathaway, J. C., and Hollister, C. D., 1972. Lithology of sediments from the western North Atlantic, Leg XI, Deep Sea Drilling Project. In Hollister, C. D., Ewing, J. I., et al., Init. Repts. DSDP, 11: Washington (U.S. Govt. Printing Office), 901-949.

Lancelot, Y., and Winterer, E. L., 1980. Evolution of the Moroccan oceanic basin and adjacent continental margin-a synthesis. In Lancelot, Y., Winterer, E. L., et al., Init. Repts. DSDP, 50: Washington (U.S. Govt. Printing Office), 801-821.

Marschalko, R., 1970. The origin of disturbed structures in Carpathian turbidites. Sed. Geol., 4:5-18.

Mitchum, R. M., Jr., 1984. Seismic stratigraphic criteria for recognition of submarine fans. Characteristics of Gulf Basin Deep-Water Sediments and Their Exploration Potential. Fifth Ann. Res. Conf., Gulf Coast Sect., Soc. Econ. Paleontol. Mineral. Found., pp. 6385.

Mitchum, R. M., Jr., and Vail, P. R., 1977. Seismic stratigraphic interpretation. In Payton, C. E. (Ed.), Stratigraphic Interpretation of Seismic Data. Am. Assoc. Pet. Geol. Mem., 26:135-144.

Mutti, E., 1978. Distinctive, thin-bedded turbidite facies and related depositional environments in the Eocene Hecho Group (South-central Pyrenees, Spain). Sedimentology, 24:107-132.

1979. Turbidites et cones sous-marins profonds. In Homewood, P. (Ed.), Sédimentation Détritique (Fluviatile, Littorale et Marine): Fribourg, Switzerland (Institut Géologique, Université de Fribourg), pp. 353-419.

1984. Turbidite systems and their relation to depositional sequences. In Zuffa, G. G. (Ed.), Provenance of Arenites: Dordrecht, Boston, Lancaster (D. Riedel Publ. Co.), NATO ASI Series, 148:65-93.

Mutti, E., and Nilsen, T. H., 1981. Significance of intraformational rip-up clasts in deep-sea fan deposits. Int. Assoc. Sedimentol., 2nd Eur. Meeting, Bologna, Italy, Abstr., pp. 117-119. (Abstract)

Mutti, E., Nilsen, T. H., and Ricci Lucchi, F., 1978. Outer fan depositional lobes of the Laga Formation (upper Miocene and lower Pliocene), east-central Italy. In Stanley, D. J., and Kelling, G. (Eds.), Sedimentation in Submarine Canyons, Fans and Trenches: Stroudsburg, PA (Dowden, Hutchinson, and Ross), pp. 210-223.

Mutti, E., and Rucci Lucchi, F., 1972. Le torbiditi dell'Appennino Settentrionale: introduzione all' analisi di facies. Mem. Soc. Geol. It., 11:161-199.

1975. Turbidite facies and facies associations. In Mutti, E. Parea, G. C., Ricci Lucchi, F., Sagri, M., Zanzucchi, G., Ghibaudo, G., and Iaccarino, S. (Eds.), Examples of Turbidite Facies and Facies Associations from Selected Formations of Northern Apennines. 9th Int. Sedimentol. Congr., Nice, France, Exc. Guidebook, A-11:21-36.

Nelson, C. H., 1983/1984. The Astoria Fan: An elongate type fan. Geomar. Lett., 3:65-70.

Normark, W. R., Mutti, E., and Bouma, A. H., 1983/1984. Problems in turbidite research: a need for COMFAN. Geomar. Lett., 3:53-56.

Normark, W. R., Piper, D. J. W., and Hess, G. S., 1979. Distributary channels, sand lobes and mesotopography of Navy Submarine Fan, California Borderland, with applications to ancient fan sediments. Sedimentology, 26:749-774.
Normark, W. R., Piper, D. J. W., and Stow, D. A. V., 1983. Quaternary development of channels, levees, and lobes on middle Laurentian Fan. Am. Assoc. Pet. Geol. Bull., 67:1400-1409.

Piper, D. J. W., and Normark, W. R., 1983. Turbidite depositional patterns and flow characteristics, Navy Submarine Fan, California Borderland. Sedimentology, 30:681-694.

Ranke, U., von Rad, U., and Wissmann, G., 1982. Stratigraphy, facies and tectonic development of the on- and offshore Aaiun-Tarfaya Basin-a review. In von Rad, U., Hinz, K., Sarnthein, M., and Seibold, E. (Eds.), Geology of the Northwest African Continental Margin: New York (Springer), pp. 86-105.

Ricci Lucchi, F., 1978. Turbidite dispersal in a Miocene deep-sea plain: The Marnoso-Arenacea of the Northern Apennines. Geol. Mijnbouw, 57:559-576.

1983/1984. The deep-sea fan deposits of the Miocene Marnoso-Arenacea Formation, Northern Apennines. Geomar. Lett., 3:203-210.

Robertson, A. H. F., and Bernoulli, D., 1982. Stratigraphy, facies and significance of late Mesozoic and early Tertiary sedimentary rocks of Fuerteventura (Canary Islands) and Maio (Cape Verde Islands). In von Rad, U., Hinz, K., Sarnthein, M., and Seibold, E. (Eds.), Geology of the Northwest African Continental Margin: New York (Springer), pp. 498-525.

Robertson, A. H. F., and Bliefnick, D. M., 1983. Sedimentology and origin of Lower Cretaceous pelagic carbonates and redeposited clastics, Blake-Bahama Formation, Deep Sea Drilling Project Site 534, western equatorial Atlantic. In Sheridan, R. E., Gradstein, F. M., et al., Init. Repts. DSDP, 76: Washington (U.S. Govt. Printing Office), 795-828.

Schlager, W., 1980. Mesozoic calciturbidites in Deep Sea Drilling Project Hole 416A: recognition of a drowned carbonate platform. In Lancelot, Y., Winterer, E. L., et al., Init. Repts. DSDP, 50: Washington (U.S. Govt. Printing Office), 733-749.

Schlanger, S. O., and Jenkyns, H. C., 1976. Cretaceous anoxic events: Causes and consequences. Geol. Mijnbouw, 55(3-4):179-184.

Schlee, J. S., 1981. Seismic stratigraphy of the Baltimore Canyon Trough. Am. Assoc. Pet. Geol. Bull., 65:26-53.

Schlee, J. S., Behrendt, J. C., Grow, J. A., Robb, J. M., Mattik, R. E., Taylor, P. T., and Lawson, B. J., 1976. Regional geologic framework off Northeastern United States. Am. Assoc. Pet. Geol. Bull., 60:926-951.

Schlee, J. S., and Grow, J. A., 1980. Seismic stratigraphy in the vicinity of the COST No. B-3 well. In Scholle, P. A. (Ed.), Geological Studies of the COST No. B-3 Well, United States Mid-Atlantic Continental Slope Area. U.S. Geol. Surv. Circular, 833:111-116.

Scholle, P. A., 1977. Data summary and petroleum potential. In Scholle, P. A. (Ed.), Geological Studies of the COST No. B-2 Well, U.S. Mid-Atlantic Continental Shelf Area. U.S. Geol. Surv. Circular, 750:8-14.

1980. Data summary and petroleum potential. In Scholle, P. A. (Ed.), Geological Studies of the COST No. B-3 Well, United States Mid-Atlantic Continental Slope Area. U.S. Geol. Surv. Circular, 833:13-21.

Shanmugam, G., Damuth, J. E., and Moiola, R. J., 1985. Is the turbidite facies association scheme valid for interpreting ancient submarine fan environments? Geology, 13:234-237.

Shanmugan, G., and Moiola, R. J., 1982. Prediction of deep-sea reservior facies. Gulf Coast Assoc. Geol. Soc. Trans., 32:275-298.

Shepard, F. P., Dill, R. F., and von Rad, U., 1969. Physiography and sedimentary processes of La Jolla Submarine Fan and Fan Valley, California. Am. Assoc. Pet. Geol. Bull., 53(2):390-420.

Sheridan, R. E., Gradstein, F. M., et al., 1983. Site 534: Blake-Bahama Basin. In Sheridan R. E., Gradstein, F. M., et al., Init. Repts. DSDP, 76: Washington (U.S. Govt. Printing Office), 141-340.

Stow, D. A. V., 1981. Laurentian Fan: Morphology, sediments, processes and growth patterns. Am. Assoc. Pet. Geol. Bull., 65:375393.

Stow, D. A. V., Howell, D. G., and Nelson, C. H., 1983/1984. Sedimentary, tectonic and sea-level controls on submarine fans and slope-apron turbidite systems. Geomar. Lett., 3:57-64.

Tucholke, B. E., and Mountain, G. S., 1979. Seismic stratigraphy, lithostratigraphy and paleosedimentation patterns in the North American Basin. In Talwani, M., Hay, W., and Ryan, W. B. F. (Eds.), Deep Drilling Results in the Atlantic Ocean: Continental Margins 
and Paleoenvironment. Am. Geophys. Un., Maurice Ewing Ser., 3:58-86.

Vail, P. R., Hardenbol, J., and Todd, R. G., 1984. Jurassic unconformities, chronostratigraphy and sea level changes from seismic stratigraphy and biostratigraphy. Am. Assoc. Pet. Geol. Mem., 36 (pt. 7):129-144.

Vail, P. R., Mitchum, R. M., Jr., Thompson, S., III, Todd, R. G., Sangree, J. M., Widmier, J. M., Bubb, J. N., and Hatlelid, W. G., 1977. Seismic stratigraphy and global changes in sea level. In Payton, C. E. (Ed.), Stratigraphic Interpretation of Seismic Data. Am. Assoc. Pet. Geol. Mem., 26:49-212.

Van Vliet, A., 1978. Early Tertiary deep-water fan of Guipuzcoa, Northern Spain. In Stanley, D. J., and Kelling, G. (Eds.), Sedimentation in Submarine Canyons, Fans and Trenches: Stroudsburg, PA (Dowden, Hutchinson and Ross), pp. 190-209.

von der Borch, C. C., Sclater, J. G., et al., 1974. Site 218. In von der Borch, C. C., Sclater, J. G., et al., Init. Repts. DSDP, 22: Washington (U.S. Govt. Printing Office), 325-348.

von Rad, U., and Arthur, M. A., 1979. Geodynamic, sedimentary and volcanic evolution of the Cape Bojador continental margin (NW Africa). In Talwani, M., Hay, W., and Ryan, W. B. F. (Eds.), Deep Drilling Results in the Atlantic Ocean: Continental Margins and Paleoenvironment. Am. Geophys. Un., Maurice Ewing Ser. 3:187203.

von Rad, U., Auzende, J.-M., Ruellan, E., and CYAMAZ Group, 1985. Stratigraphy, structure, paleoenvironment and subsidence history of tine Mazagan Escarpment off Central Morocco: a synthesis of the results of the CYAMAZ deep diving expedition. Oceanol. Acta., Spec. Vol., 5:161-182.

von Rad, U., and Einsele, G., 1980. Mesozoic-Cainozoic subsidence history and paleobathymetry of the Northwest African continental margin (Aaiun Basin to DSDP Site 397). In Kent, P., Laughton, A. S., Roberts, D. G., and Jones, E. W. J. (Eds.), The Evolution of
Passive Continental Margins in the Light of Recent Deep Drilling Results. Phil. Trans. R. Soc. London, Ser. A, 294:37-50.

von Rad, U., and Sarti, M., 1986. Early Cretaceous "events" in the evolution of the eastern and western North Atlantic continental margins. Geol. Rundschau., 75(1):139-158.

von Rad, U., and Wissmann, G., 1982. Cretaceous-Cenozoic history of the West Saharan continental margin (NW Africa): Development, destruction and gravitational sedimentation. In von Rad, U., Hinz, Sarnthein, M., and Seibold, E. (Eds.), Geology of the Northwest African Continental Margin: New York (Springer), pp. 106-131.

Walker, R. G., 1985. Mudstone and thin-bedded turbidites associated with the Upper Cretaceous Wheeler Gorge Conglomerates, California: A possible channel-levee complex. J. Sed. Petrol., 55:279290.

Webb, G. B., 1981. Stevens and earlier Miocene turbidite sandstones, southern San Joaquin Valley, California. Am. Assoc. Pet. Geol. Bull., 65:438-465.

Winterer, E. L., and Hinz, K., 1984. Results of DSDP Leg 79 seaward of the Mazagan Plateau of central Morocco-a synthesis. In Hinz, K., Winterer, E. L., et al., Init. Repts. DSDP, 79: Washington (U.S. Govt. Printing Office), 893-919.

Wiedmann, J., Butt, A., and Einsele, G., 1978. Vergleich von marokkanischen Kreide-Küstenaufschlüssen und Tiefseebohrungen (DSDP): Stratigraphie, Paleoenvironment und Subsidenz an einem passive Kontinentalrand. Geol. Rundschau, 67(2):454-508.

Wissmann, G., and von Rad, U., 1979. Seismic structure, continental basement, and Mesozoic sediments from the Mazagan Plateau off Morocco. "Meteor" Forsch.-Ergebn., Reihe C, 31:1-20.

Date of Initial Receipt: 21 March 1985

Date of Acceptance: 17 January 1986 


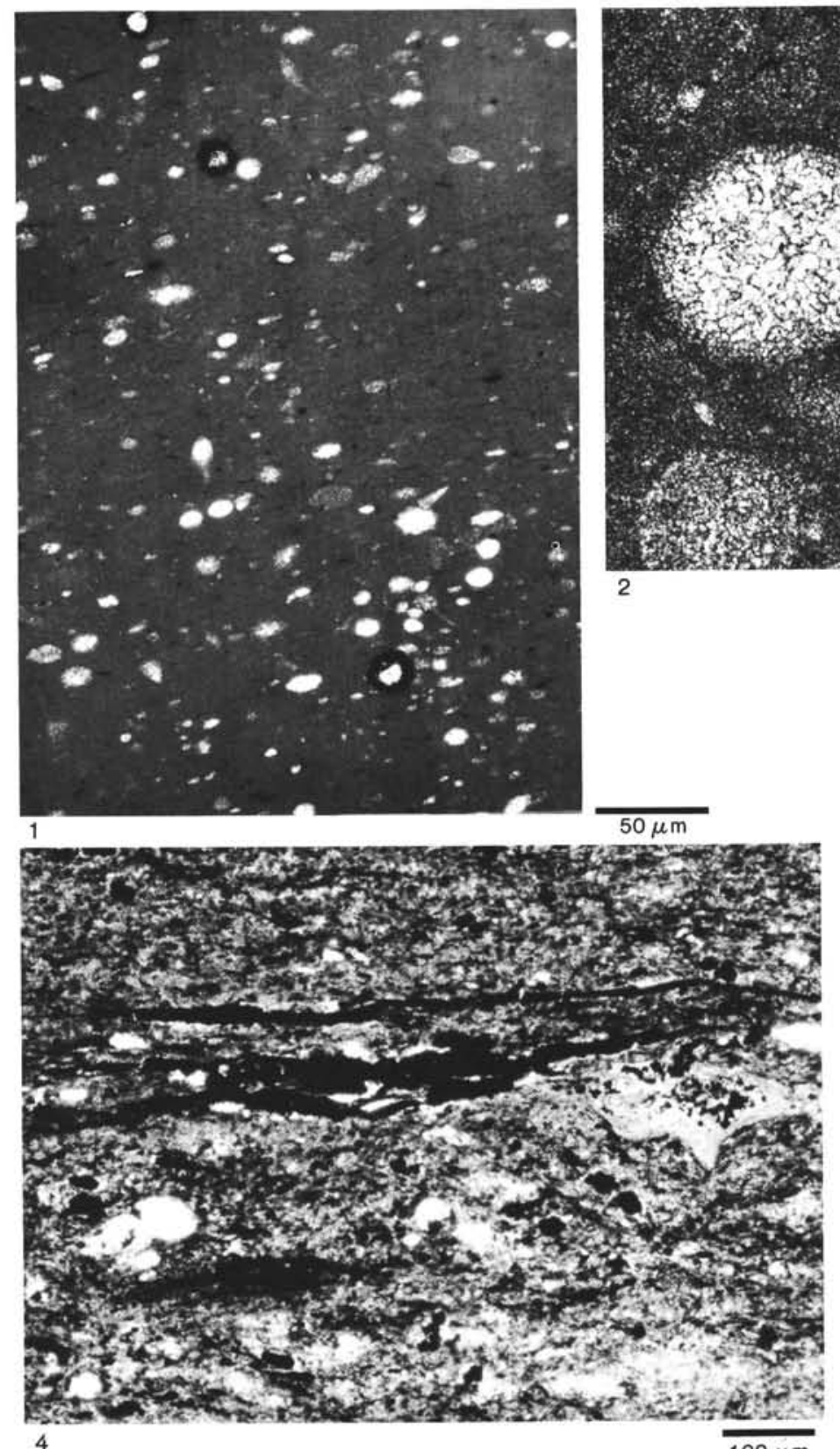

4

$100 \mu \mathrm{m}$

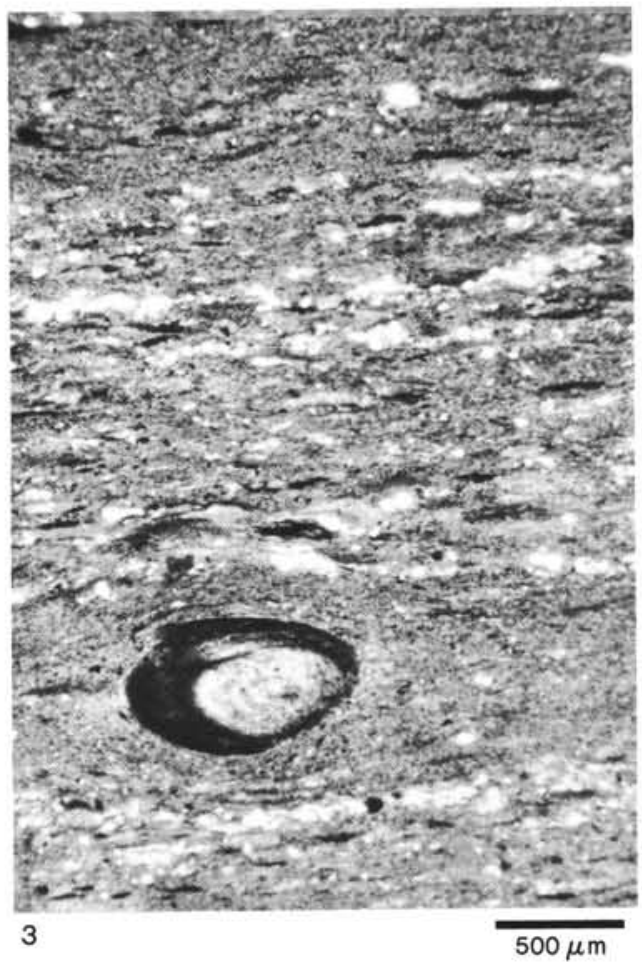

Plate 1. Photomicrographs of bioturbated and laminated pelagic limestone to marlstone. 1. Sample 603B-69-2, 59-61 cm; radiolarian-bearing, bioturbated, nannofossil limestone; the ?radiolarian ghosts are slightly compressed and mostly calcite-filled, sometimes pyritized (Hauterivian). 2. Sample 603B-77-2, 43-46 cm; detail of micritic, bioturbated nannofossil limestone with recrystallized, calcitized radiolarians (Valanginian). 3. Sample 603B-44-2, 43-47 cm; laminated organic-matter-rich nannofossil marlstone; note large fish vertebra and streaks of organic matter (Barremian), 4. Sample 603B-49-4, 17-21 cm; organic-matter-rich, nannofossil marlstone with laminae of concentrated organic matter (mainly plant debris) and yellowish fish debris (center right), small circular fossils (ghosts of foraminifers, ?radiolarians, ?calcispheres) (Barremian). 

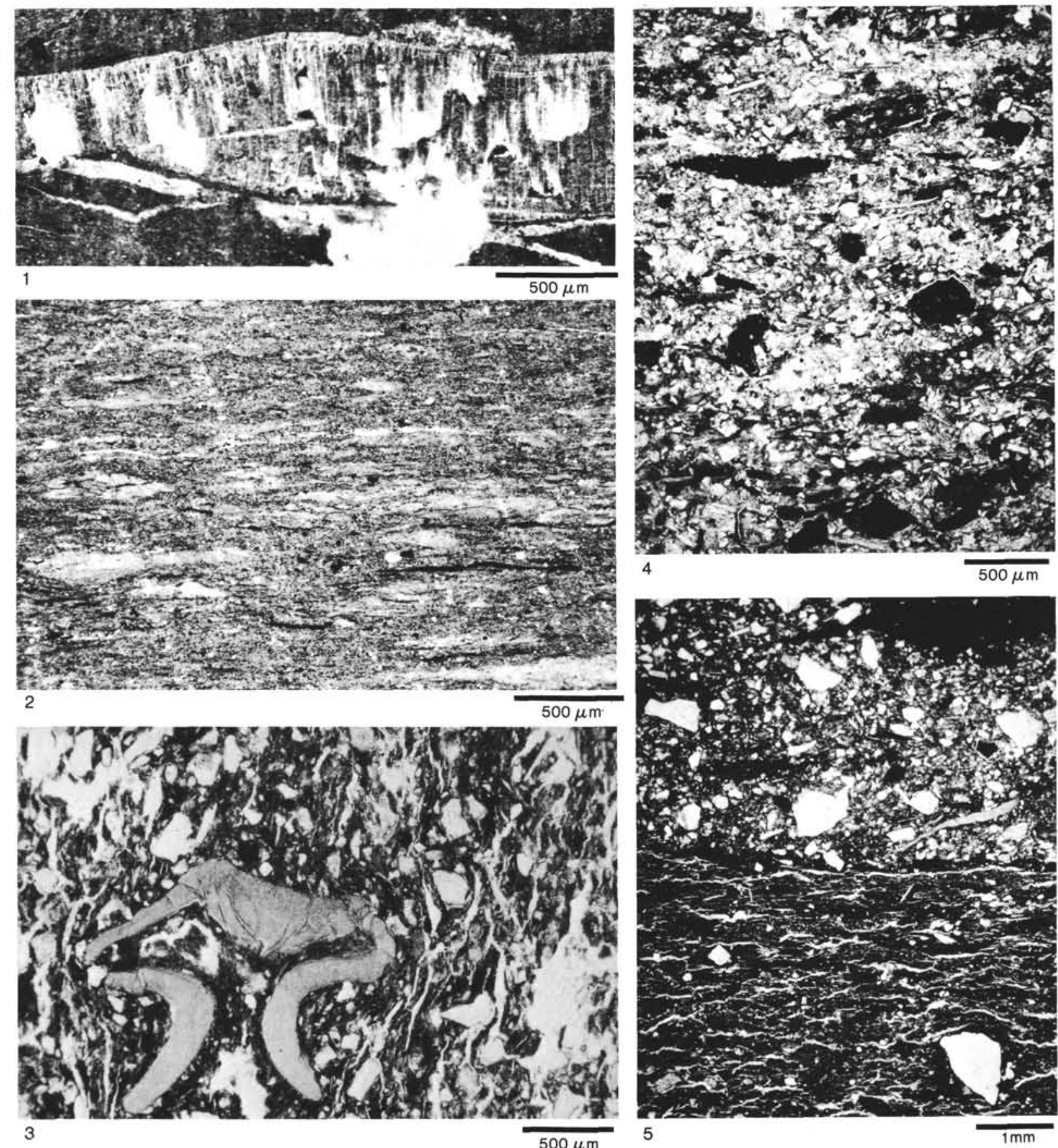

Plate 2. Photomicrographs of Early Cretaceous laminated marlstones and coarse-grained turbiditic sandstones. 1. Sample 603B-80-2, 143-145 cm; large mollusk (?Inoceramus) fragment in laminated marlstone (Valanginian); secondary collophane fills voids. 2. Sample 603B-63-4, 38-40 cm; laminated marlstone with streaky, lensoidal "lamination" (?horizontal Planolites burrows) (Hauterivian). 3. Sample 603B-51-1, 58-62 cm; very poorly sorted, medium sandstone (clay-rich quartz graywacke) with large mollusk fragment (redeposited from shallower water), quartz, feldspar, organic matter, and pyrite (Barremian). 4. Sample 603B-54-3, 58-60 cm; clay- and plant-material-rich, mica-bearing, poorly sorted, fine to medium quartz sandstone (Barremian). 5. Sample 603B-53-3, $82-84 \mathrm{~cm}$; marlstone with scattered quartz grains, overlain by very poorly sorted turbiditic sandstone $\left(\mathrm{T}_{\mathrm{a}}\right)$ containing large mollusk and plant fragments (Barremian). 

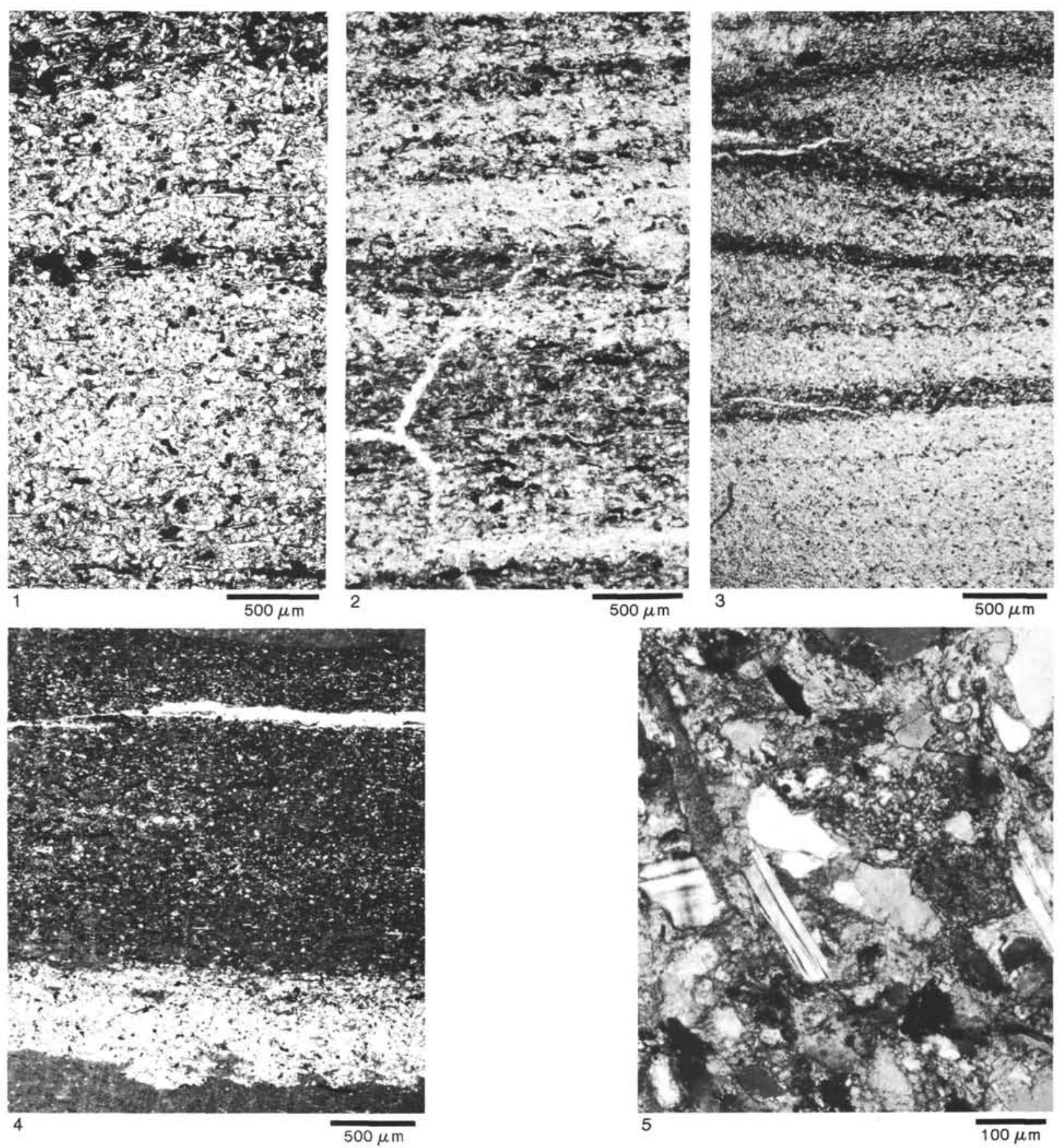

Plate 3. Photomicrographs of laminated and massive turbiditic sandstones. 1. Sample 603B-65-3, 118-120 cm; well-sorted, laminated, mica-rich quartz siltstone $\left(\mathrm{T}_{\mathrm{b}}\right)$; dark layers contain more mica, clay, and plant fragments (Hauterivian). 2. Sample 603B-36-2, 12-15 cm; laminated, mica-rich quartz siltstone $\left(\mathrm{T}_{\mathrm{b} / \mathrm{c}}\right)$; light-colored layers contain angular quartz and mica, and traces of glauconite, pyrite, and clay; dark laminae contain more clay than mica and pyrite, and only traces of quartz (Aptian-Albian). 3. Sample 603B-36-2, 12-15 cm; parallel- and ripple-laminated quartz siltstone $\left(\mathrm{T}_{\mathrm{b} / \mathrm{c}}\right.$ ); dark layers rich in clay, mica, pyrite, and organic matter. 4. Sample 603B-53-5, 13-15 cm; silty turbidite overlain by laminated quartz-rich marlstone; note the distinct lower boundary and imperceptible size grading (Barremian). 5. Sample 603B-55-3, 65-68 cm; calcite-cemented, moderately sorted quartz arenite with quartz, feldspar, crystalline rock fragments, muscovite, ?chert, and claystone fragments (Barremian). 

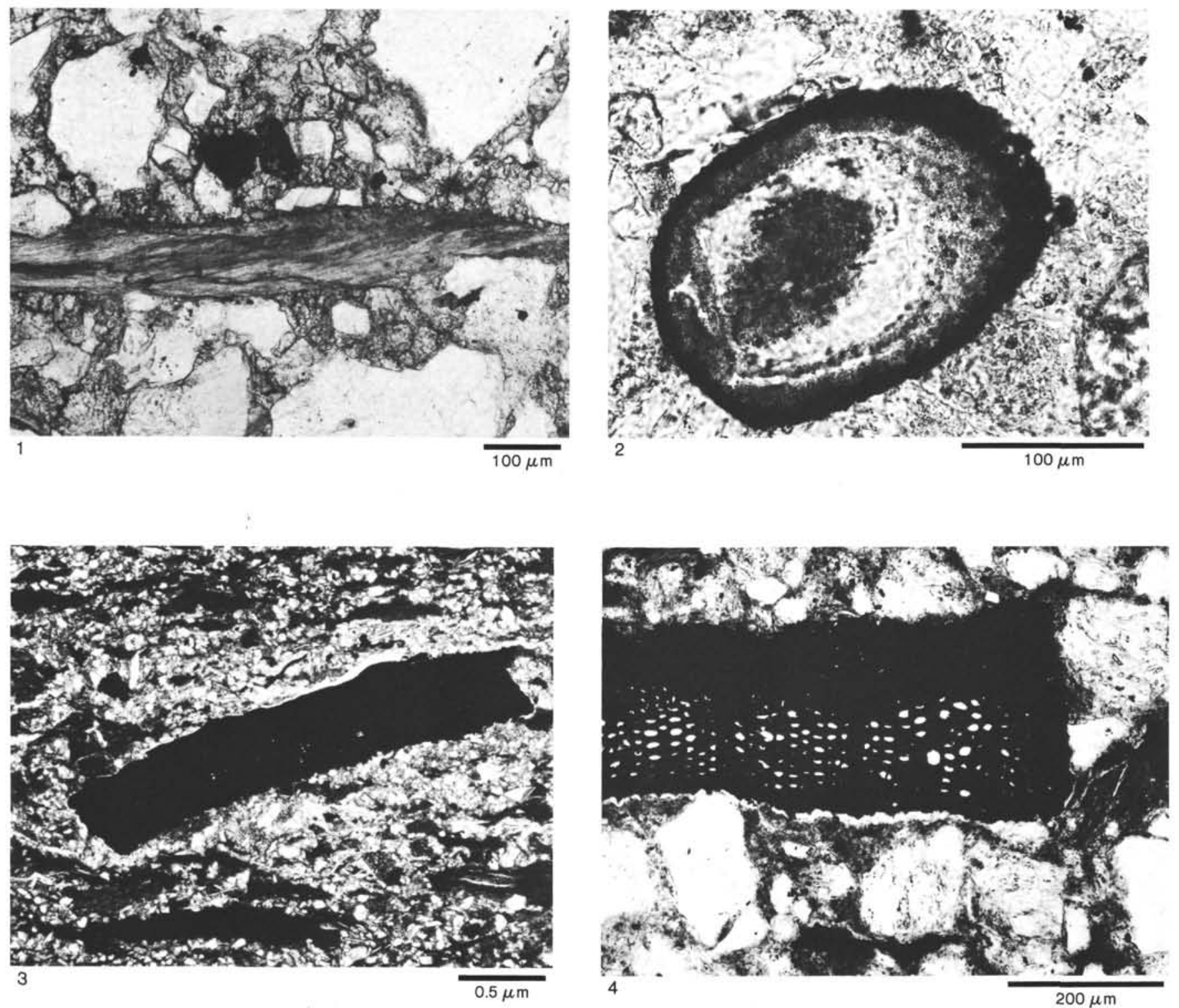

Plate 4. Photomicrographs of redeposited shallow-water components in turbiditic sandstones. 1. Sample 603B-60-4, 51-54 cm; moderately sorted, calcite-cemented quartz arenite $\left(T_{3}\right)$ with large pelecypod fragment (Barremian). 2. Sample 603B-57-3, 128-130 cm; coated grain with dolomite nucleus surrounded by clay matrix and coated by pyrite (Barremian turbiditic quartz graywacke). 3. Sample 603B-60-4, 47-51 cm; partly pyritized wood fragment in pebbly mudstone (debris-flow unit at the top of thick sandy turbidite); note the elongate mudstone fragments and fine-grained quartz and mica in clayey-calcitic matrix (Barremian). 4. Sample 603B-61-2,93-95 cm; large pyritized plant fragment (cell structure) in very poorly sorted, mica-bearing, feldspar- and clay-rich quartz graywacke (Barremian). 

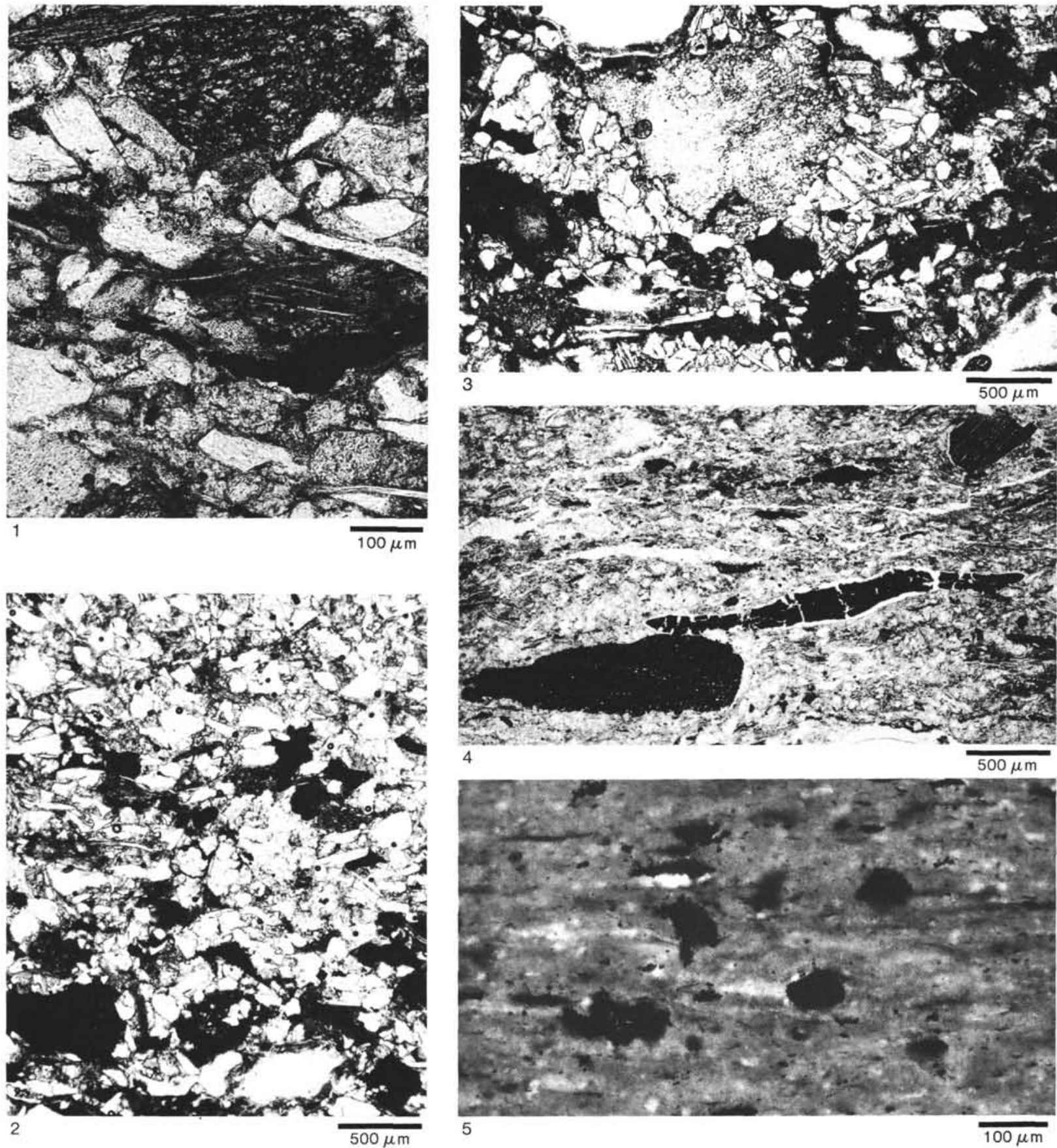

Plate 5. Photomicrographs of turbiditic sandstones and mudstones. 1. Sample 603B-68-1, 44-49 cm; base of poorly sorted sandy turbidite; note the large micritic siderite/dolomite (?) pebble (top and base), mica flakes, and quartz grains in mostly calcitic (largely clayey) matrix (Hauterivian). 2. Sample 603B-68-1, 44-49 cm; moderately sorted, calcite-cemented, mica-rich fine to medium quartz sandstone with ?dolomicrite and shale fragments (Hauterivian). 3. Sample 603B-73-4, 78-80 cm; moderately sorted, calcite-cemented medium quartz sandstone with large echinoid (top) and many shale fragments (Hauterivian/Valanginian). 4. Sample 603B-66-4, 112-114 cm; poorly sorted, plant-material-rich, clayey quartz siltstone with large pyritized (center) and unpyritized (cell structure) plant fragments (Hauterivian). 5. Sample 603B-69-2, 59-61 cm; organic-matter-rich, carbonate-free turbiditic claystone; note the pyritized plant material and radiolarians (?) (Hauterivian). 

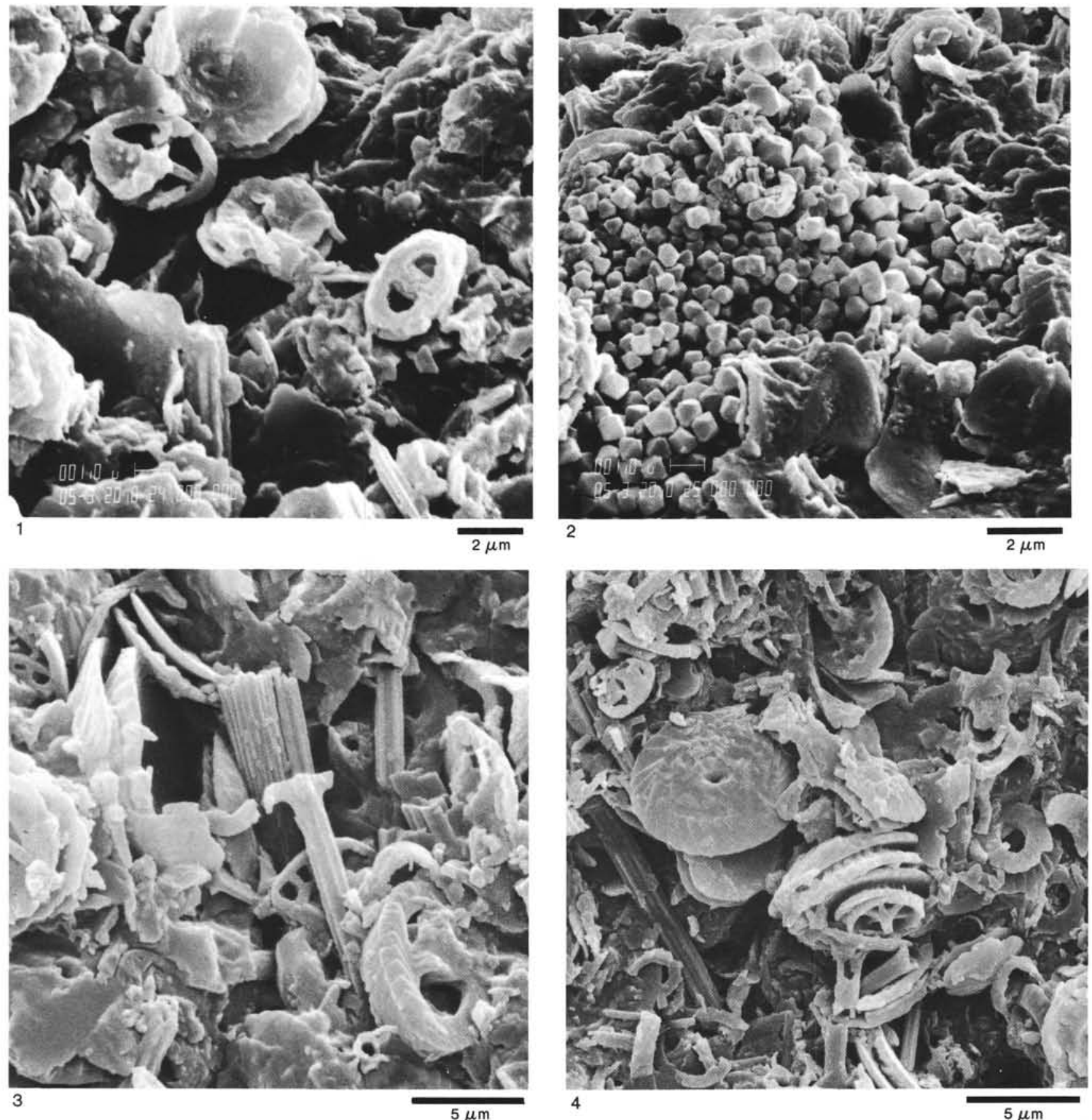

Plate 6. Scanning electron micrographs of laminated and turbiditic marlstones. 1, 2. Sample 603B-44-2, 43-47 cm; laminated clay-rich nannofossil marlstone (Barremian); (1) SEM 1620/7, 5000 × ; poorly preserved coccoliths in a micrite matrix (calcite and smectite flakes), (2) SEM 1620/8, $5000 \times$; pyrite concretion (minute cubes) in a micritic-clayey matrix. 3, 4. Sample 603B-59-1, 26-28 cm; turbiditic, homogeneous nannofossil marlstone (Barremian), (3) SEM 1641/1, 4000 $\times$, and (4) SEM 1641/4, 4000 $\times$, show well-preserved coccoliths and rhabdoliths in a micritic (and slightly clayey) matrix with much pore space. 


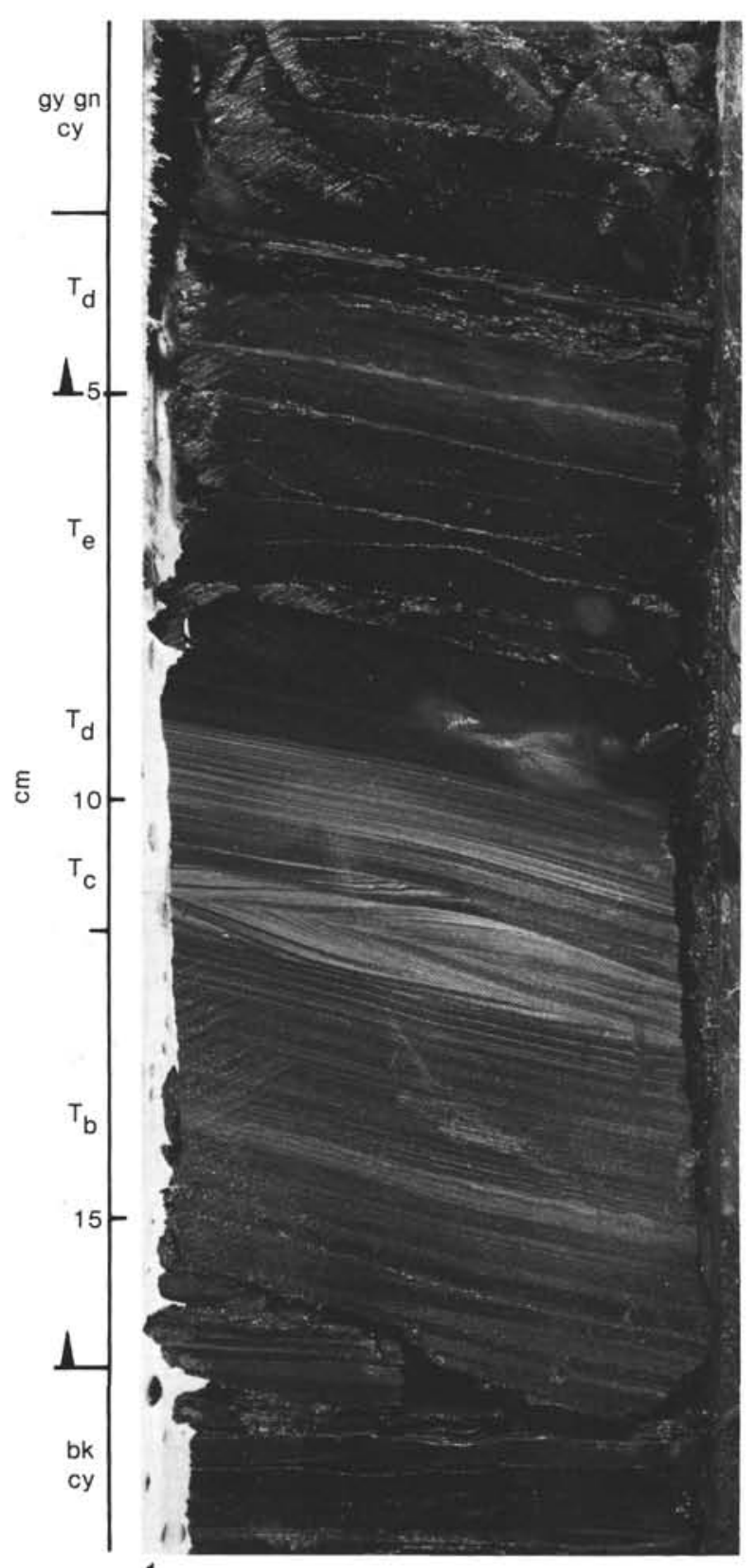

1

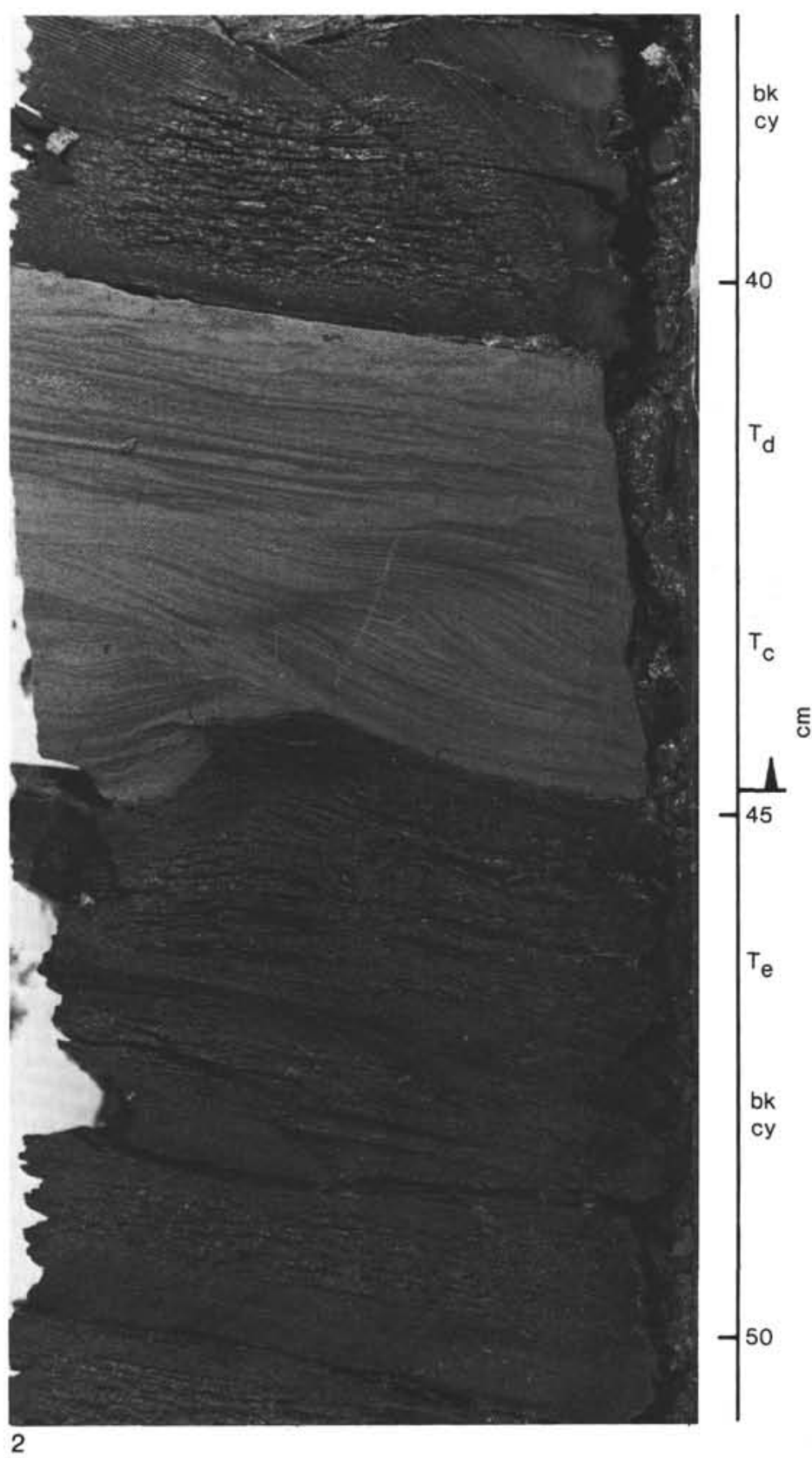

2

Plate 7. Aptian-Albian siltstone turbidites (Hatteras Formation). 1. Sample 603B-36-2, 5-17 cm; siltstone/claystone turbidite displaying a basemissing Bouma sequence $\left(\mathrm{T}_{\mathrm{b}}\right.$ through $\mathrm{T}_{e}$; facies $\left.\mathrm{D}_{1}\right)$; black laminated claystones (bk cy; "black shale") with siltstone laminae occur above and below turbidite; above $3 \mathrm{~cm}$, dark greenish-gray bioturbated hemipelagic claystone (gy gn cy). 2. Sample 603B-36-3, 42-45 cm; very fine sandstone/siltstone layer showing climbing ripple laminae at the base and parallel laminae at the top, enclosed in parallel-laminated black turbiditic claystone ("black shale"); note scour at the base of siltstone. Triangles indicate bases of turbidites. 

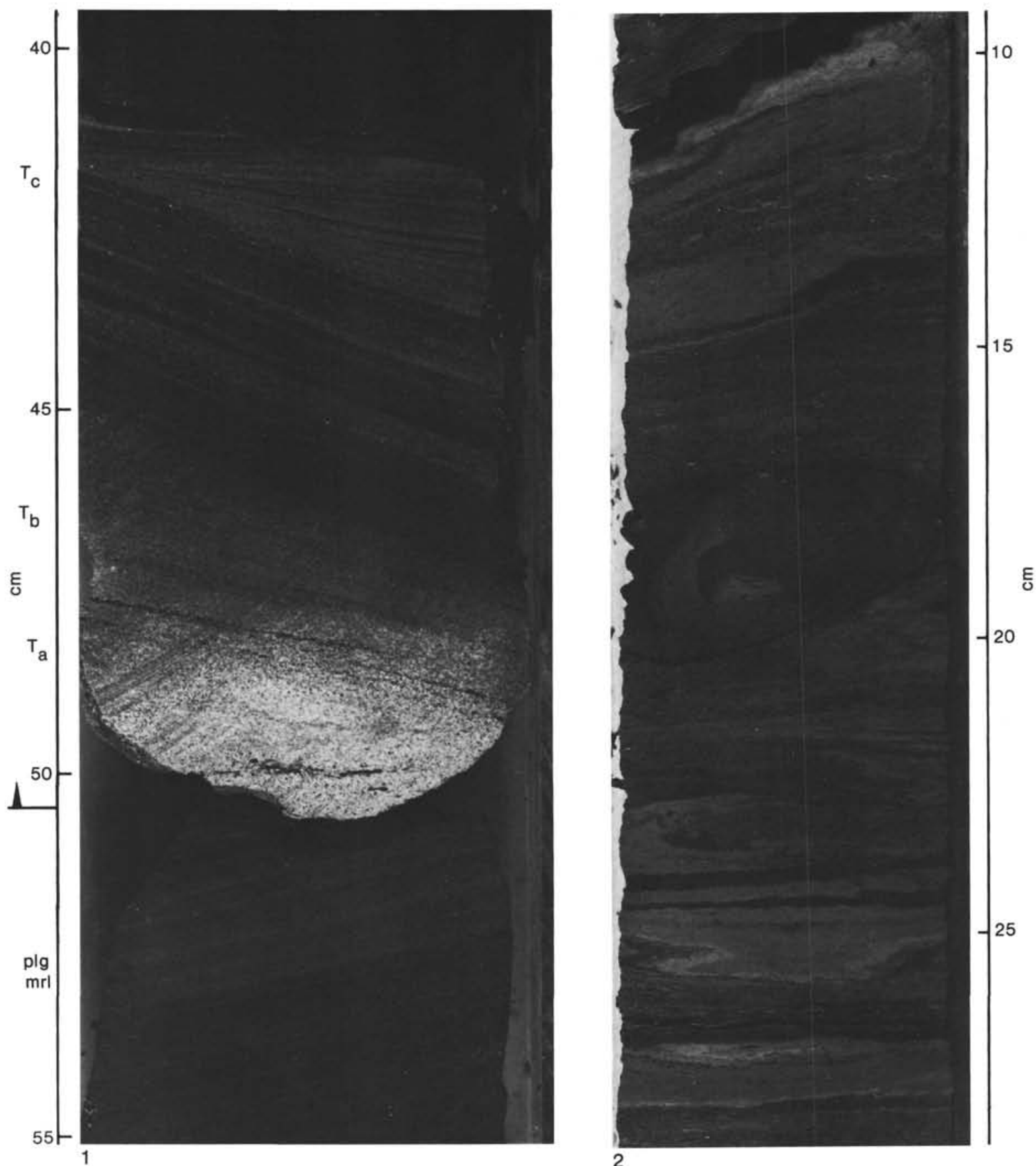

Plate 8. Turbidites and related debris-flow units (Barremian). 1. Sample 603B-53-1, 40-55 cm; graded turbidite layer of facies C, showing structureless, medium-grained sandstone at base $\left(\mathrm{T}_{a}\right)$, and a parallel- to ripple-laminated fine sandstone at top $\left(\mathrm{T}_{b}\right.$ and $\left.\mathrm{T}_{c}\right)$; black claystone above 41 $\mathrm{cm}$ is $\mathrm{T}_{\mathrm{e}}$. 2. Sample 603B-55-2,10-28 cm; detail of debris-flow layer present at the top of a sandstone bed approximately $1 \mathrm{~m}$ thick; contorted layers of pelagic limestone and marl and claystone clasts are included in clayey sandstone matrix; note the crenulated appearance of folded bedding planes. plg $\mathrm{mrl}=$ hemipelagic marlstone. 

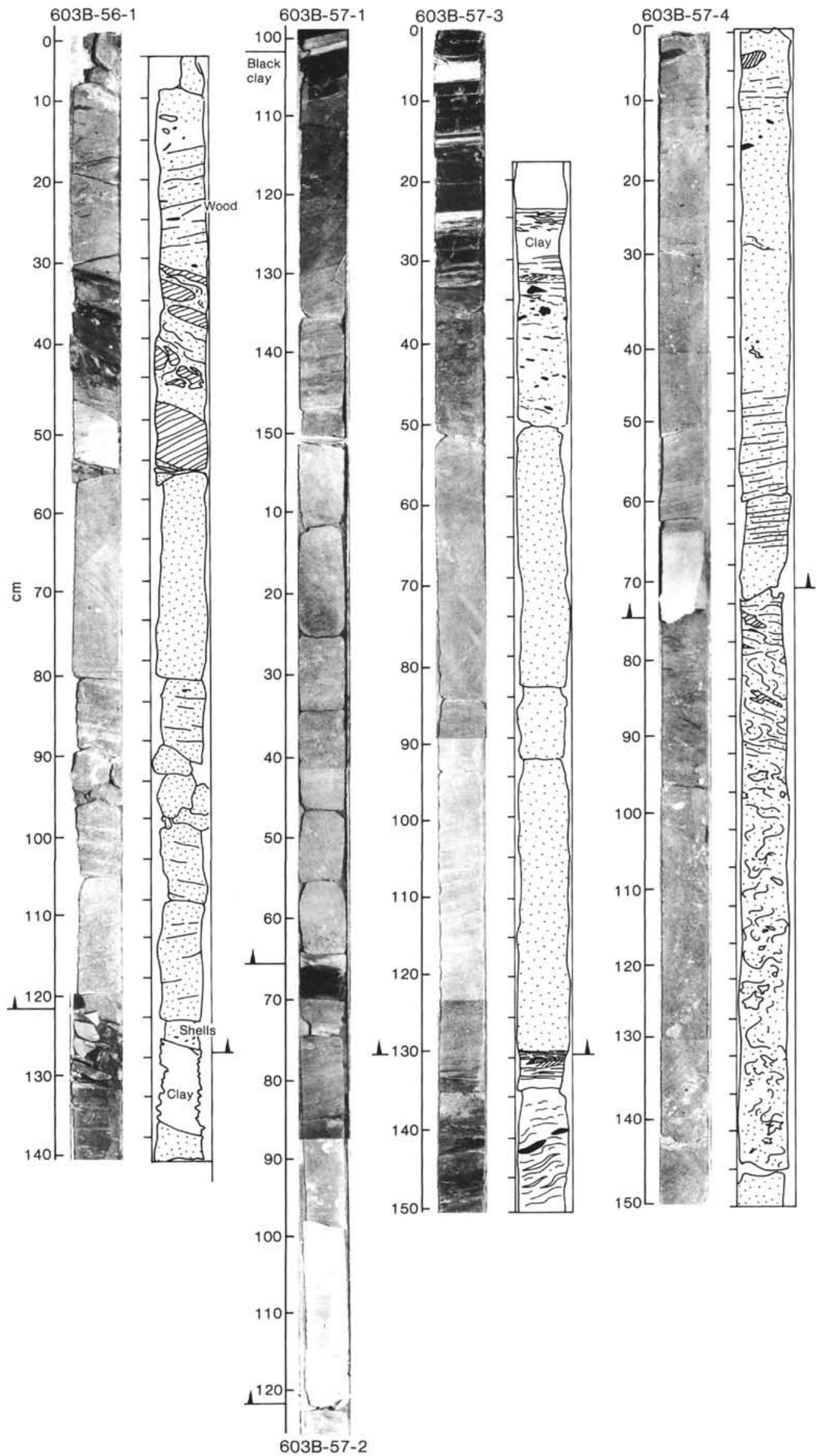

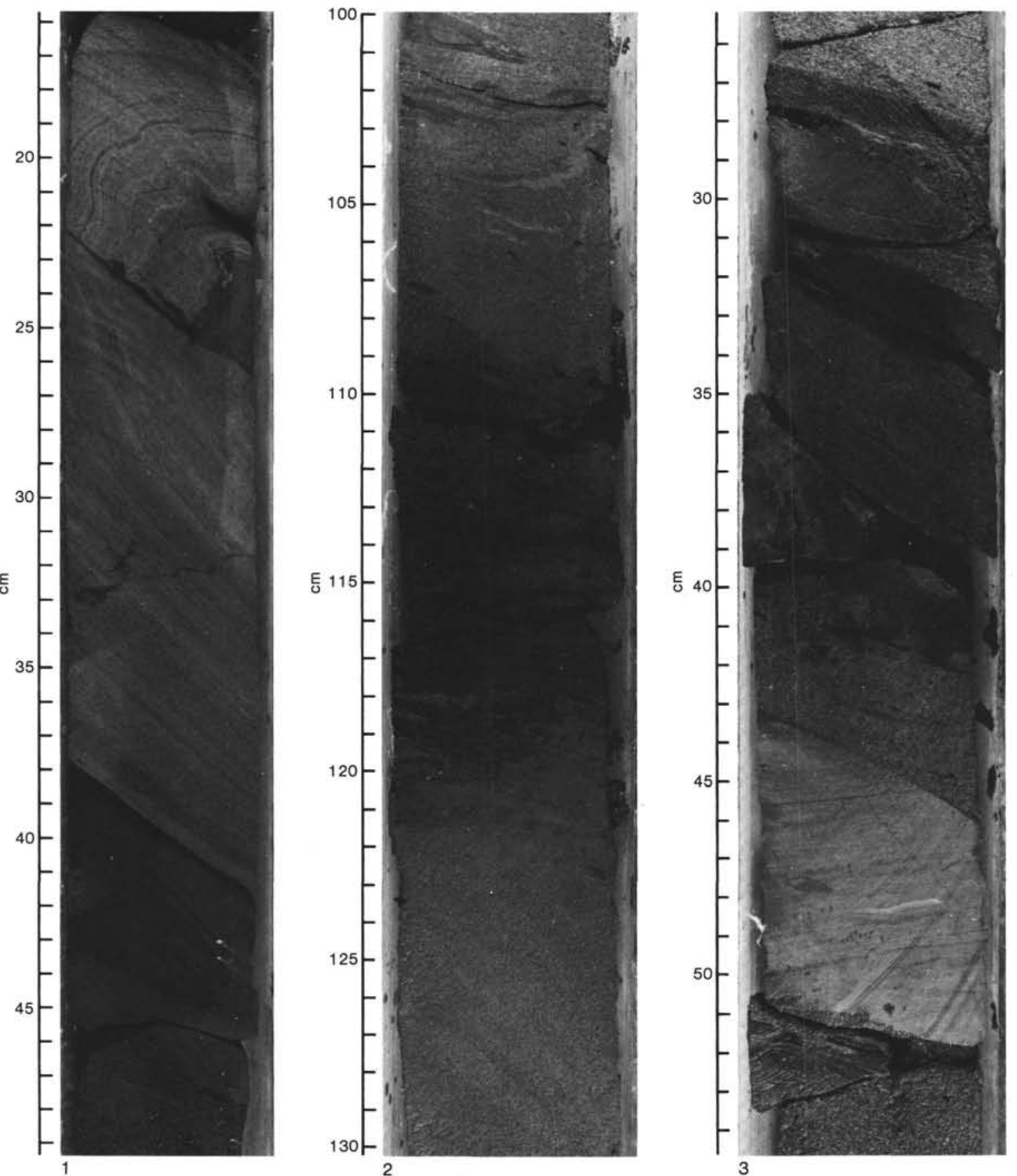

Plate 10. Slump and debris-flow units in Barremian turbidites. 1. Sample 603B-58-1, 16-49 cm (detail of Plate 11); slump fold in pelagic laminated marlstone; note the microfaulting and the crenulated geometry of folded bedding planes in the upper half of the photograph; large wood fragment at $22 \mathrm{~cm}$. 2. Sample $603 \mathrm{~B}-58-1,100-130 \mathrm{~cm}$; detail of a shale-clast- and wood-fragment-rich layer resting at the top (122 cm) of a structureless, clayey sandstone bed with a total thickness of $80 \mathrm{~cm}$. 3. Sample 603B-56-1, 28-53 cm (detail of Plate 9, Fig. 1); matrix-supported breccia interval; large, rounded clasts of claystone and pelagic marlstone (laminated) are included in a clayey sandstone matrix.

Plate 9. Thick-bedded sandstone turbidites of facies C, with slurried division (type 2); Sections 603B-56-1 and 603B-57-1 through 4 (Barremian). Sequence of clayey sandstone beds, approximately 1 to $1.5 \mathrm{~m}$ thick, containing shale and sandstone clasts, scattered (Sample $603 \mathrm{~B}-57-4,80-150 \mathrm{~cm}$ ) or concentrated in breccia layers (Sample 603B-56-1, 25-55 cm; Sample 603B-57-4, 0-10 cm). Note the massive (Sample 603B-57-2, 0-60 cm) or chaotic appearance of sandstone beds (Sample 603B-57-4, 80-150 cm); the parallel, thick laminae (Samples 603B-56-1, 80-110 cm and 603B-57-3, 100-120 cm), and the ripple-laminated layer at top ( $\mathrm{T}_{\mathrm{c}}$ ) (Samples 603B-57-3, 30-33 cm and $130-133 \mathrm{~cm})$. A calcite-cemented sandstone layer, massive $\left(\mathrm{T}_{\mathrm{a}}\right)$ and parallel-laminated $\left(\mathrm{T}_{\mathrm{b}}\right)$, may be present at the base of turbidite beds $(603 \mathrm{~B}-57-4,70-80 \mathrm{~cm})$. Triangles indicate bases of turbidites. 


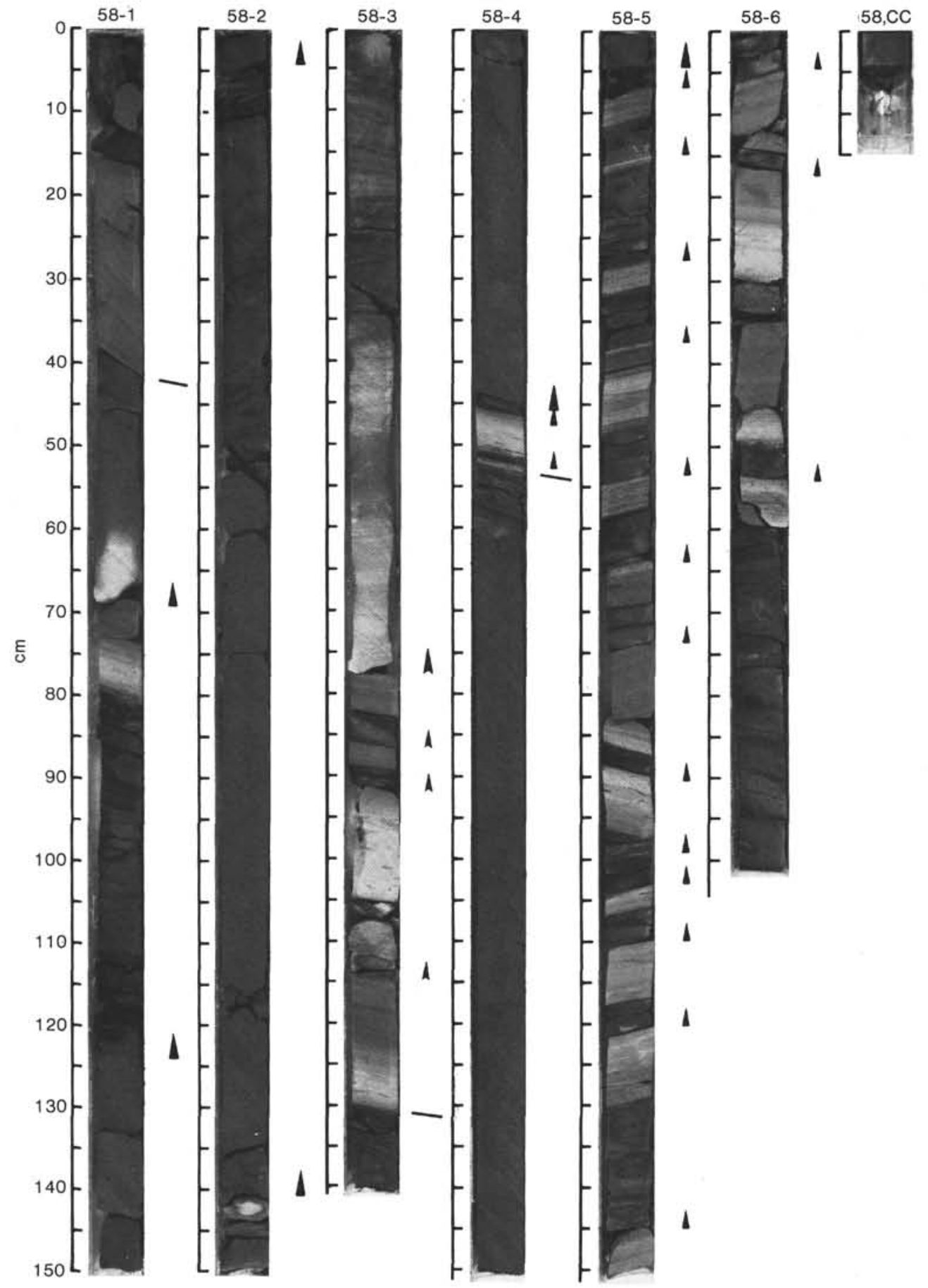

Plate 11. Facies C turbidites, with slurried division (type 2). Core 603B-58 (Barremian); note the sequence of clayey sandstone beds, approximately $1 \mathrm{~m}$ thick, entirely massive or faintly parallel-laminated and bearing claystone clasts at the top (Samples $603 \mathrm{~B}-58-1,0 \mathrm{~cm}$ to $603 \mathrm{~B}-58-3,76 \mathrm{~cm}$; 603B-58-4; 603B-58-6, 65-100 cm); massive sandstone beds are interbedded with bioturbated limestone/laminated marlstone cycles; thin, homogeneous, "black" claystone turbidites (facies $\mathrm{D}_{3}$ ) are present in Section 603B-58-5, lower half. Triangles indicate bases of turbidites.

Plate 12. Chaotic breccia beds and debris-flow deposits (type 1). 1. Sample 603B-64-1, 9-82 cm; disorganized, matrix-supported breccia bed containing large, streaked-out, and plastically deformed clasts of black claystone; the matrix is clayey sandstone to sandy claystone; note the massive sandstone layer $\left(T_{2}\right)$ at base $(70-83 \mathrm{~cm})$. 2. Sample 603B-70-2, 10-46 cm; detail of the base of clayey sandstone bed displaying a massive texture with locally convoluted bedding; plastically deformed clasts of sandstone are present at the base; note the parallel laminae in the lowermost layer, probably related to viscous laminar flow; total thickness of bed is $60 \mathrm{~cm}$. 3 . Sample 603B-59-3, 45-75 cm; close-up core photograph of a slumped horizon consisting of a package of alternating pelagic nannofossil marlstone, black claystone, and sandstone layers that are intensely folded and locally highly disrupted; note the small-scale slump folding and the crenulated geometry of folded layers; the slumped horizon rests on a bed of massive sandstone, whose top appears at the bottom of the photograph $(74-75.5 \mathrm{~cm})$. blm = bioturbated limestone; plm = hemipelagic laminated marlstone; bk cy = black claystone. 

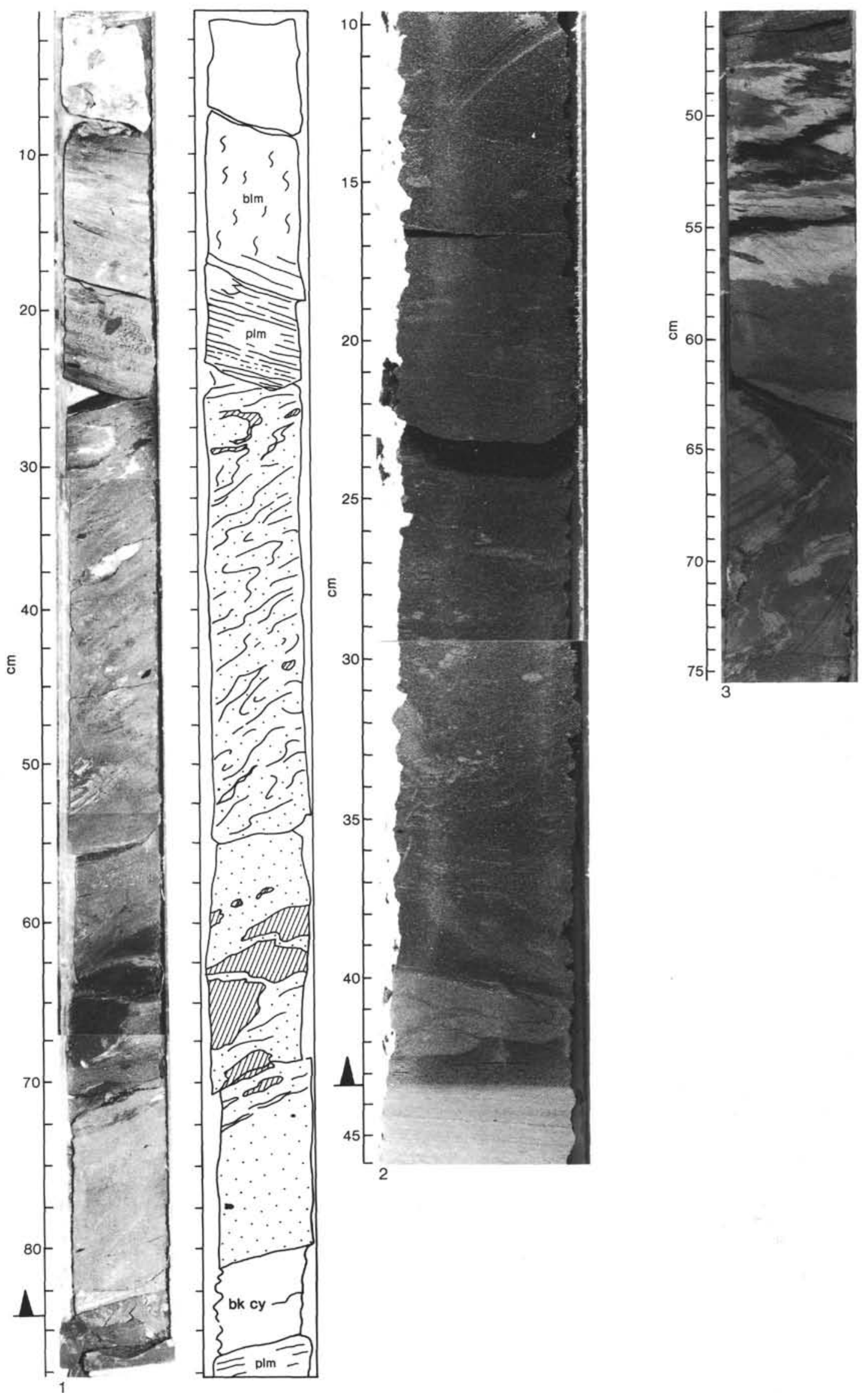

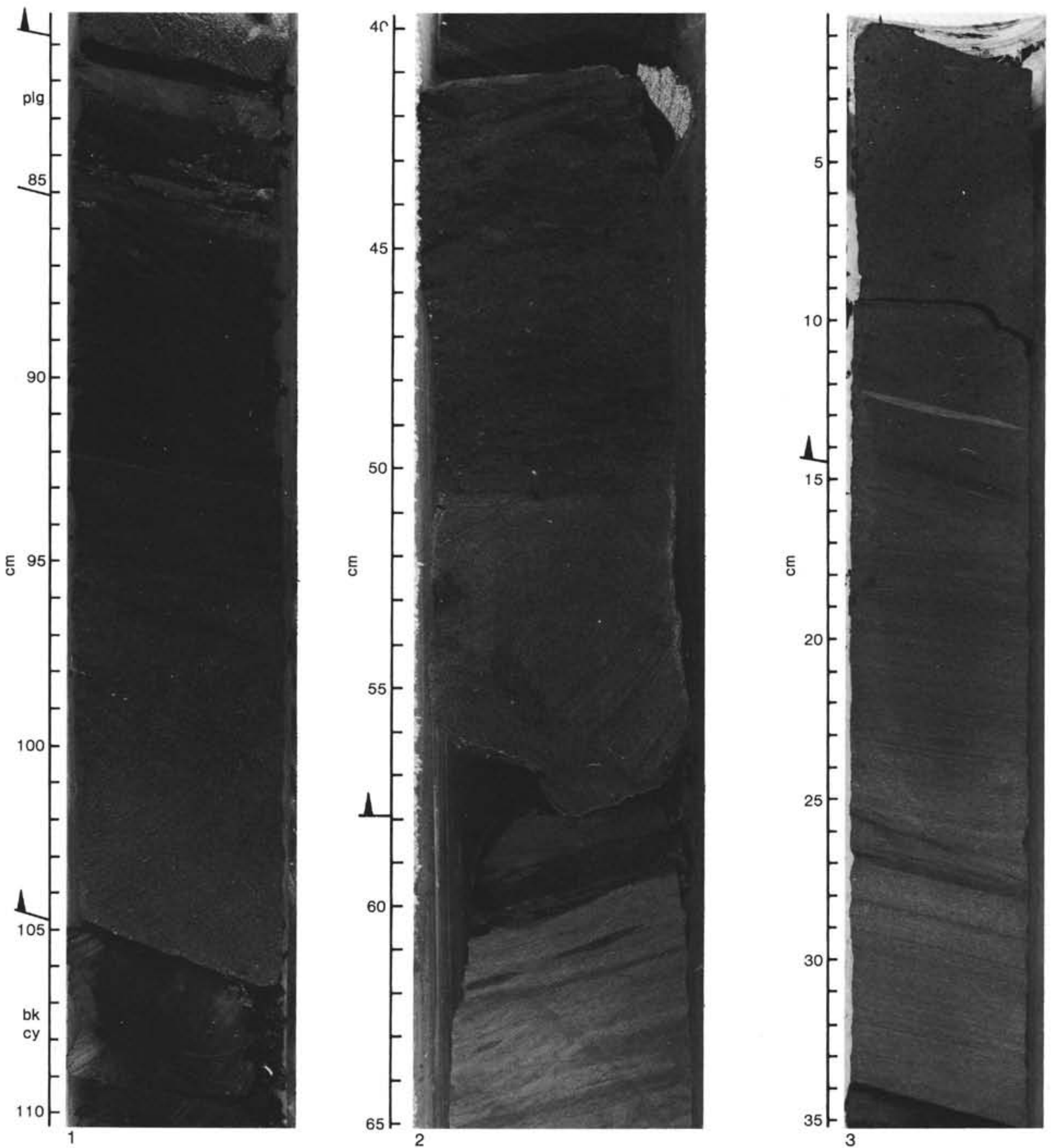

Plate 13. Core 603B-60. Close-up photographs. 1. Sample 603B-60-1,80-110 cm; fine sandstone turbidite showing parallel laminae in the lower half, grading upward into structureless black claystone (facies $D_{1}$ ); bioturbated pelagic marl (plg) occurs at $82-86 \mathrm{~cm}$. 2. Sample 603B-60-4, 40$65 \mathrm{~cm}$; thin-bedded turbidite of facies $C$, with slurried division (type 4), showing a chaotic, clayey sandstone interval that contains scattered clasts and flakes of black claystone and that rests on a layer of massive, fine sandstone $\left(\mathrm{T}_{\mathrm{a}} ; 50.5-57.5 \mathrm{~cm}\right)$; a black claystone layer $\left(\mathrm{T}_{e}\right)$ occurs at the top of the photograph (above $41 \mathrm{~cm}$ ). 3. Sample 603B-60-3, 0-35 cm; tight isoclinal fold ("drag structure") at the base of a clayey sandstone turbidite; sandstone bed above is $120 \mathrm{~cm}$ thick; note the fine-grained, clayey texture of the sandstone and the flattened, streaked-out clast of pelagic marlstone at the base. Triangles indicate bases of turbidites. 

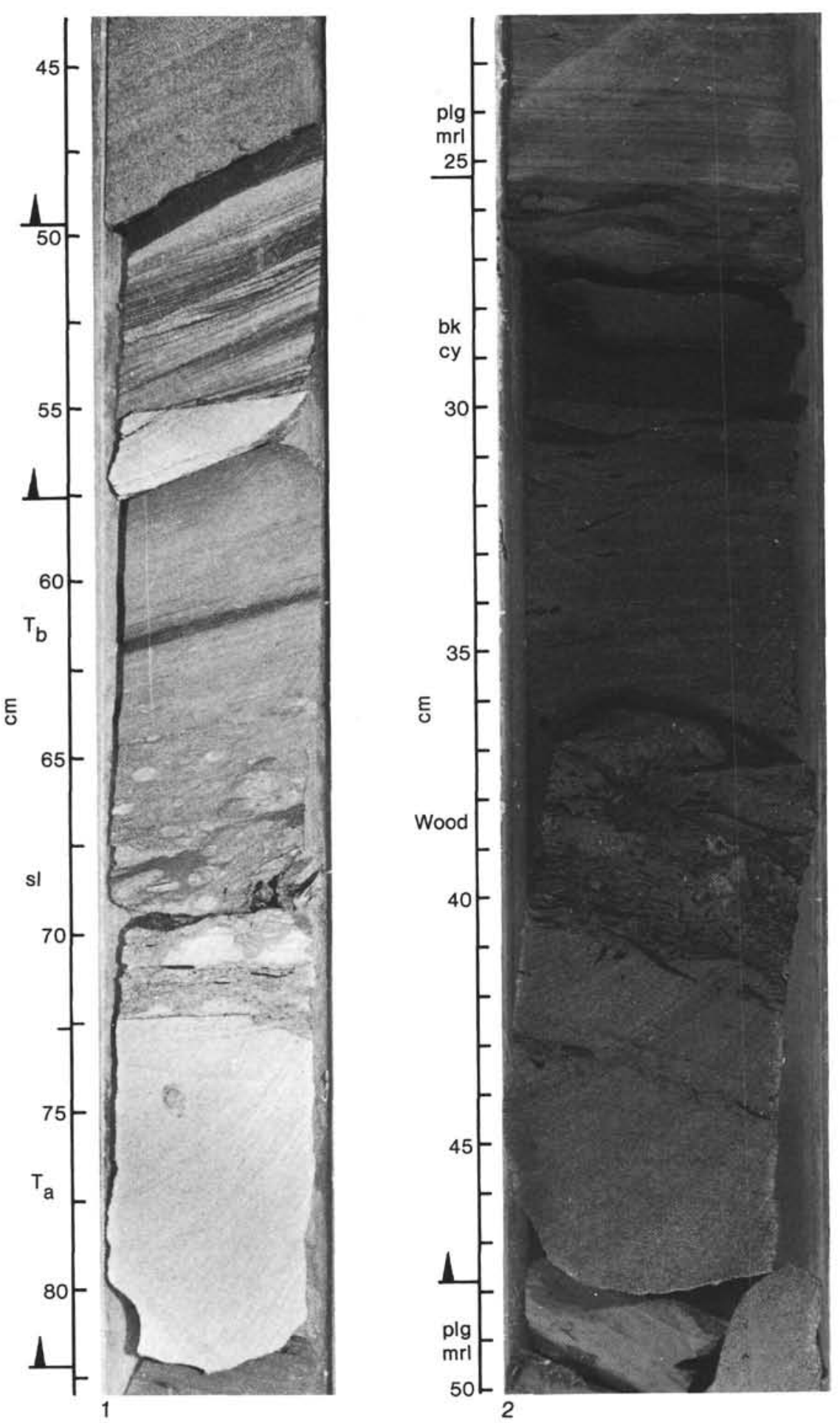

Plate 14. Thin-bedded turbidites of facies C, with slurried division (type 4), (Hauterivian). 1. Sample 603B-61-1, 58-82 cm; typical, chaotic, shale-clast-rich interval (slurried bed [sl]) included between structureless, locally faintly laminated fine sandstone $\left(\mathrm{T}_{\mathrm{a}}\right)$ and parallel-laminated siltstone $\left(\mathrm{T}_{\mathrm{b}}\right)$, respectively, at the base and the top. Facies $\mathrm{D}_{1}$ turbidite at $50-58 \mathrm{~cm}$. 2. Sample $603 \mathrm{~B}-61-5,22-50 \mathrm{~cm}$; thin slurried bed showing a chaotic, clayey sandstone horizon rich in pyritized plant fragments (at the base) and streaked-out shale clasts (at the top); this chaotic interval is sandwiched between a layer of fine-grained sandstone, massive or faintly laminated and cemented by calcite ( $41-47 \mathrm{~cm}$ ), and black claystone (bk cy) at top (28-30 cm); laminated hemipelagic marlstone (plg mrl) is seen at the top of the photograph. Triangles indicate bases of turbidites. 

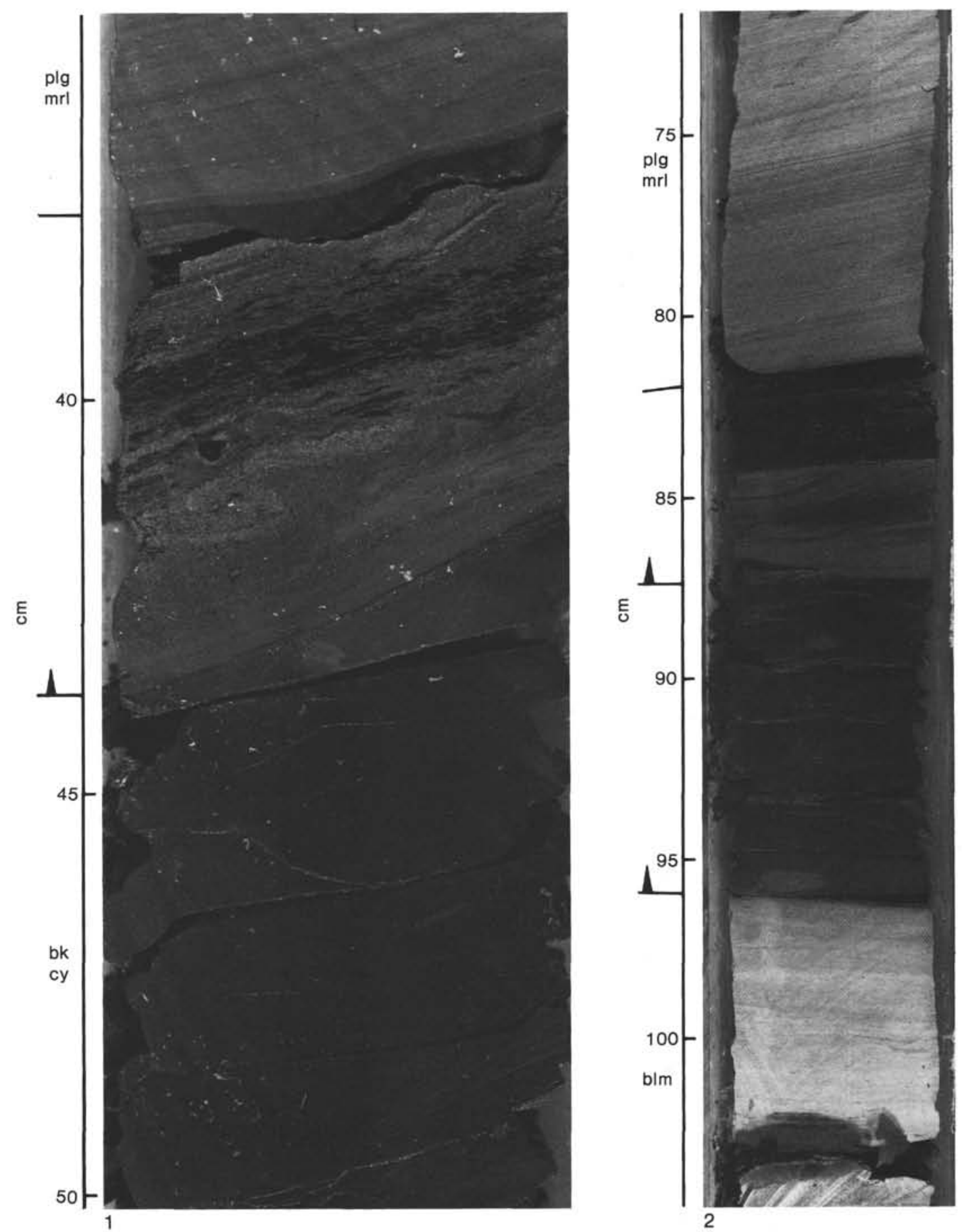

Plate 15. Hauterivian thin-bedded turbidites. 1. Sample 603B-63-3, 35-50 cm; thin, coarse-grained slurried bed $(37.5-44 \mathrm{~cm})$ showing a structureless sandstone layer at the base overlain by a horizon, $3 \mathrm{~cm}$ thick, rich in small claystone clasts and coalified plant fragments; the sandstone at base contains streaked-out clasts and flakes of marlstone; convolute, "wavy" lamination at base (viscous flow lamination deformed by drag effect) indicates flow toward the left; parallel-laminated fine-grained sandstone $\left(\mathrm{T}_{\mathrm{b}}\right)$ grading upward to claystone $\left(\mathrm{T}_{e}\right)$ occurs in the topmost $2 \mathrm{~cm}$; laminated nannofossil marlstone (plg mrl) occurs above $37.5 \mathrm{~cm}$. 2. Sample $603 \mathrm{~B}-65-4,72-105 \mathrm{~cm}$; claystone turbidite of facies $\mathrm{D}_{3}$ and ripplelaminated siltstone/claystone couplet of facies $\mathrm{D}_{1}(81-87 \mathrm{~cm})$, included in pelagic bioturbated limestone (blm) below and laminated nannofossil marlstone above. Triangles indicate bases of turbidites.

Plate 16. Total core photograph, Core 603B-62. Sequence of thin slurried beds, type 4 (Sample 603B-62-1, 22-32 cm and 62-78 cm) and thicker units of type 2 (Samples 603B-62-2, $107 \mathrm{~cm}$ through 603B-62-3, $33 \mathrm{~cm}$ and 603B-62-4, 103-150 cm); note the chaotic, or shaleclast-rich intervals at the top of massive sandstone beds; turbidites of facies $\mathrm{D}_{1}$ occur at $603 \mathrm{~B}-62-3,95-111 \mathrm{~cm}$ and $111-125$, and at 603B-62-4, 23-38 cm. plm = hemipelagic laminated marlstone. Triangles indicate bases of turbidites. 



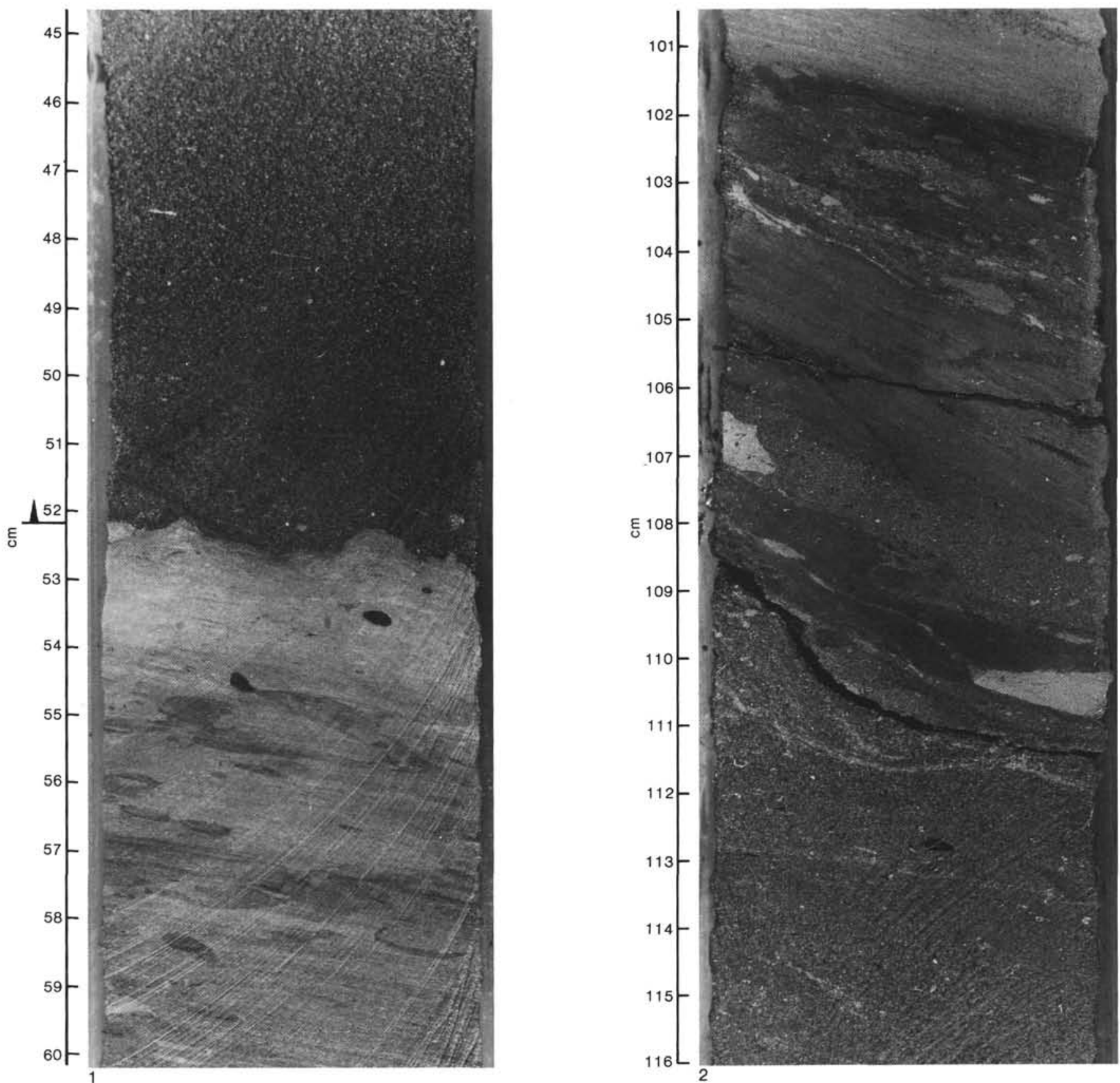

Plate 17. Close-up core photographs of Plate 16, Core 603B-62. 1. Sample 603B-62-2, 45-60 cm; detail of the base of a turbidite (45-53 cm); note the massive texture $\left(\mathrm{T}_{\mathrm{a}}\right)$ and a lack of size grading; small-scale scouring and load deformation at the base of the turbidite. 2. Sample 603B-62-4, $101-116 \mathrm{~cm}$; detail of the top of the sandstone bed at 603B-62-4, 103-150 cm (Plate 16); a thin, chaotic horizon of clayey sandstone rests at the top of massive sandstone and is overlain by hemipelagic, laminated, nannofossil marlstone; the clayey sandstone horizon contains disrupted and plastically deformed fragments of layers, and marlstone clasts (slurried bed, type 2).

Plate 18. Turbidites of facies $C$ and slurried beds, type 2, 3 and 4. Cores 603B-67 and 603B-71 (Hauterivian/Valanginian). 1. Sections 603B-67-1, 2, and 3; turbidites of facies C, approximately 1 to $1.2 \mathrm{~m}$ thick, composed of medium- to coarse-grained massive sandstone, and grading upward to structureless claystone; intervals $b$ and $c$ of the Bouma sequence are missing. Sections 603B-67-3 and -4 (parts only); slurried bed, type 4, showing distinct chaotic, clayey sandstone layer sandwiched between structureless sandstone and black claystone (cy). 2. Section 603B-71-1, thick, homogeneous, medium-grained clayey sandstone bed displaying no structures and, locally, convolute bedding; massive to convolute, calcite-cemented sandstone $\left(\mathrm{T}_{\mathrm{a}}\right)$ is present at the base (Sample 603B-71-2, 0-10 cm) (bed type 3). Section 603B-71-3; thick, homogeneous, medium-grained clayey sandstone bed bearing tiny claystone clasts scattered and concentrated in a breccia layer at 20-35 cm (slurried bed, type 2; see Plate 19, Fig. 2); a thick, black claystone turbidite (facies $\mathrm{D}_{3}$ ) is present in the interval from 603B-75-2, 30-65 cm. Triangles indicate bases of turbidites. 


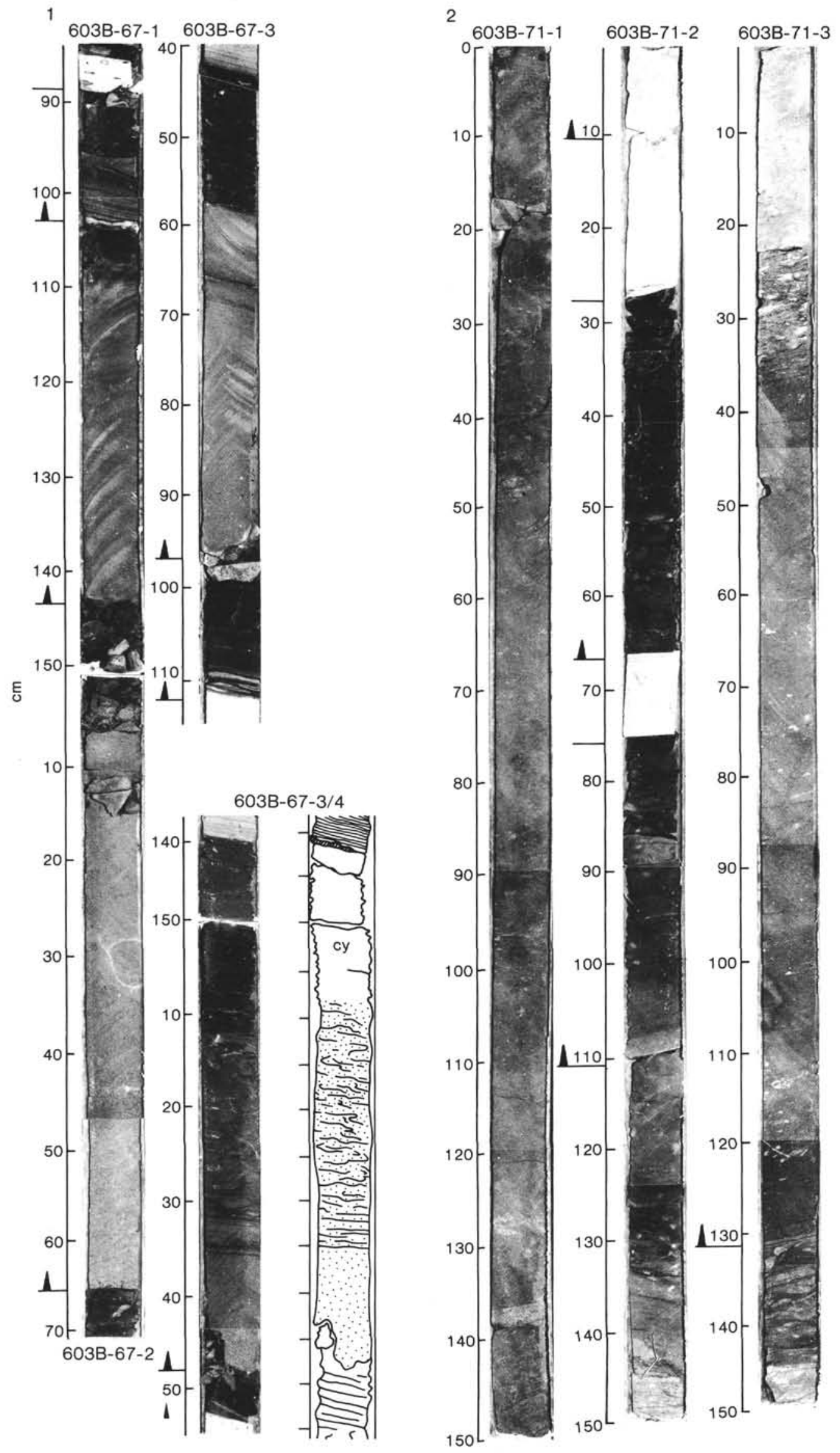



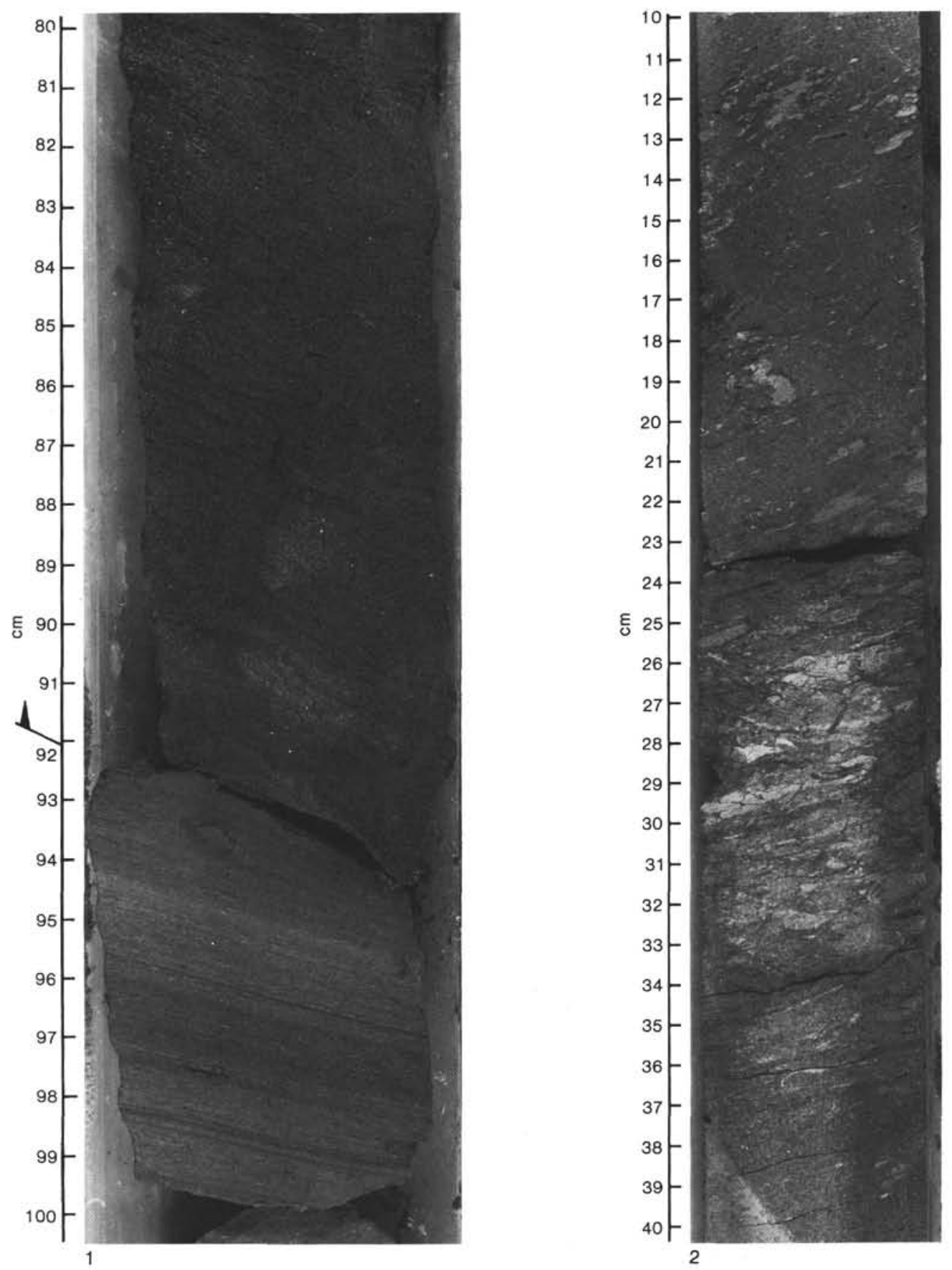

Plate 19. Close-up core photographs of Cores 68 and 71. 1. Sample $603 \mathrm{~B}-68-2,80-100 \mathrm{~cm}$; detail of the base of a 50 -cm-thick sandstone bed with no size grading and convolute bedding; note the fine grain size and the clayey texture. 2 . Sample 603B-71-3, 10-40 cm; detail of the slurried division of a turbidite bed of facies C, type 2, shown in Plate 18, Fig. 2; a shale- and sandstone-clast-rich breccia horizon (20-36 cm) occurs at the top of a homogeneous, massive sandstone $(36-40 \mathrm{~cm})$; scattered marlstone flakes and wood fragments are present in the upper half of the photograph; the breccia is supported by a clayey sandstone to sandy claystone matrix. 